UNIVERSIDADE DE SÃO PAULO

FACULDADE DE FILOSOFIA, LETRAS E CIÊNCIAS HUMANAS

DEPARTAMENTO DE LINGUÍSTICA

PROGRAMA DE PÓS-GRADUAÇÃO EM SEMIÓTICA E LINGUÍSTICA

CAROLINA FERNOCHI SANT'ANA

\title{
Uma abordagem semiótica da obra de Roberto Piva
}

SÃO PAULO - SP 


\author{
UNIVERSIDADE DE SÃO PAULO \\ FACULDADE DE FILOSOFIA, LETRAS E CIÊNCIAS HUMANAS \\ DEPARTAMENTO DE LINGUÍSTICA \\ PROGRAMA DE PÓS-GRADUAÇÃO EM SEMIÓTICA E LINGUÍSTICA
}

\title{
Uma abordagem semiótica da obra de Roberto Piva
}

\begin{abstract}
Dissertação de Mestrado apresentado ao Programa de Pós-graduação em Linguística da Faculdade de Filosofia, Letras e Ciências Humanas - USP/São Paulo, como requisito para obtenção do título de Mestre em Semiótica e Linguística Geral.
\end{abstract}

Linha de pesquisa: Semiótica

Orientador: Prof. Dr. Antonio Vicente Pietroforte 


\section{CAROLINA FERNOCHI SANT'ANA}

\section{Uma abordagem semiótica da obra de Roberto Piva}

Dissertação de Mestrado apresentada ao

Programa de Pós-graduação em Linguística da Faculdade de Filosofia, Letras e Ciências

Humanas - USP/São Paulo, como requisito para obtenção do título de Mestre em Semiótica e Linguística Geral.

Linha de pesquisa: Semiótica

Orientador: Prof. Dr. Antonio Vicente Pietroforte

Aprovada em:

MEMBROS COMPONENTES DA BANCA EXAMINADORA:

Prof $^{\circ}$ Dr. Antonio Vicente Seraphim Pietroforte

Universidade de São Paulo

Julgamento: Assinatura:

Prof $^{\circ}$ Dr. Ivã Carlos Lopes

Universidade de São Paulo

Julgamento: Assinatura:

$\operatorname{Prof}^{\mathrm{a}} \mathrm{Dr}^{\mathrm{a}}$. Loredana Limoli

Universidade de Londrina

Julgamento: Assinatura:

USP - São Paulo 
Para meus pais e meus irmãos Para minha família Para meus amigos 


\section{AGRADECIMENTOS}

A minha mãe, por ter me ensinado a ler e a escrever. A meu pai, por nunca ter deixado faltar livros e sempre ter incentivado a busca por conhecimento. Aos meus irmãos pelo companheirismo constante. A todos eles, pelo apoio.

Ao meu mestre, Antonio Vicente Pietroforte, pela amizade, pelos ensinamentos e pela confiança.

À Faculdade de Filosofia, Letras e Ciências Humanas da Universidade de São Paulo, pela formação.

Aos professores Norma Discini, Ivã Lopes e Elisabeth Harkot, pelos excelentes cursos ministrados e pelas orientações que muito que contribuíram para elaboração desta dissertação.

Aos amigos do grupo de pós: Carol Tomasi, Thiago, Cleyton e Débora pela companhia, pela ajuda, pela paciência e pela diversão.

Ao Akira, pela paciência e estímulo.

Às amigas Fabiana e Hellen, por fazerem parte da minha vida, pelas risadas em momentos difíceis e pelo apoio sempre. 


\section{RESUMO}

SANTANA, Carolina Fernochi. Uma abordagem semiótica da obra de Roberto Piva.

2013. 127 f. Dissertação (Mestrado) - Faculdade de Filosofia, Letras e Ciências Humanas, Universidade de São Paulo, 2013.

Esta dissertação busca, em linhas gerais, fazer uma abordagem semiótica da obra de Roberto Piva para, através disso, identificar as bases estruturais do seu projeto poético em cada momento de produção. O organizador dos volumes, Álcir Pécora, faz um divisão da obra de Piva em três momentos poéticos, cada um correspondente a um livro. Um estrangeiro na legião corresponde ao primeiro momento, de viés beat, whitmanniano e pessoano; Mala na mão \& asas pretas compreende o segundo momento, de traços psicodélicos e experimentais e Estranhos sinais de saturno compreende o terceiro momento, predominantemente místico e visionário. Este trabalho adotará essa divisão, e buscará explicar, através da semiótica, como é construído o sentido em cada um desses momentos. Segundo Pécora, a opção pela organização dos poemas se deu por ordem cronológica. Essa ordem, no entanto, representa um "desenho cronológico particular", pois os três "surtos de produção" representam, cada um, um momento poético diferente. Este trabalho propõe, através da seleção e análise de poemas que condensem a poética dominante de cada volume, descrever as estruturas fundamentais, as escolhas narrativas e os procedimentos discursivos que compõe a unidade de cada momento poético da obra de Piva.

Palavras-chave: Semiótica. Linguistica. Roberto Piva. Subversão. 


\begin{abstract}
This work seeks, in general, make a semiotic approach to the work of Roberto Piva, with the purpuse of identify the structural basis of his poetic project in every moment of production. The organizer of the volumes, Alcir Pécora, makes a division of the work into three poetic moments, each one corresponding to a book. Um estrangeiro na legião corresponds to the first moment, with features related to the north american beat literature. Mala na mão \& asas pretas is the second book, that is the second moment, of psychedelic and experimental traces. Estranhos sinais de Saturno is the third book, predominantly mystical and visionary. This paper will adopt this division, and seek to explain, through semiotics of Greimas, how the meaning is created in each of these moments. According to Pécora, the option for organizing the poems took place in chronological order. Each book, however, represents a different poetic moment. This paper proposes, through the selection and analysis of some poems from each volume, describe the fundamental structures, narrative choices and discursive procedures that make up the unit of each volume and of the whole work of Piva.
\end{abstract}

Keywords: Semiotics. Linguistics. Roberto Piva. Subversion. 


\section{Sumário}

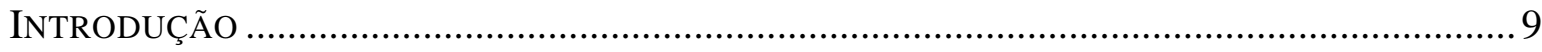

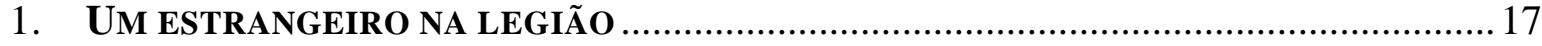

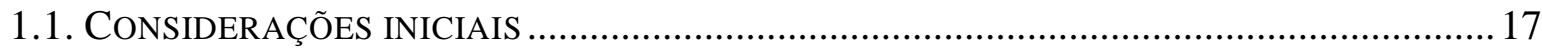

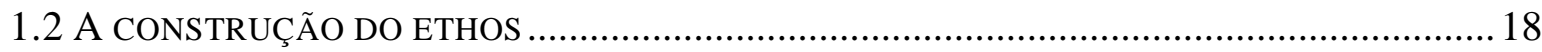

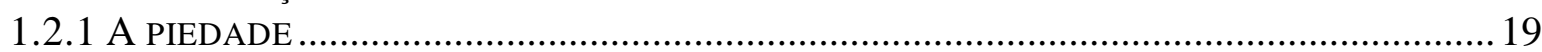

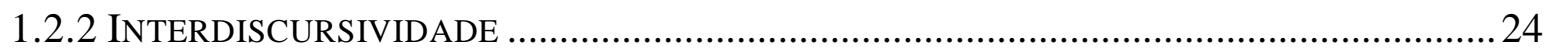

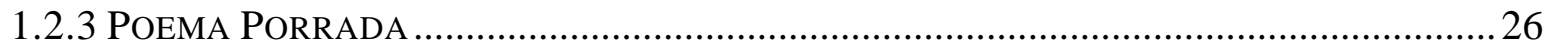

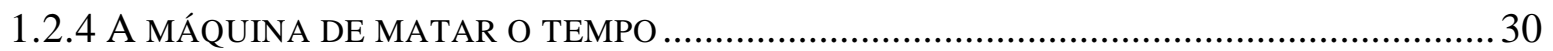

1.3 CONSIDERAÇõES SOBRE A (ANTI-)ÉTICA E A (I)MORALIDADE EM ROBERTO PIVA .......33

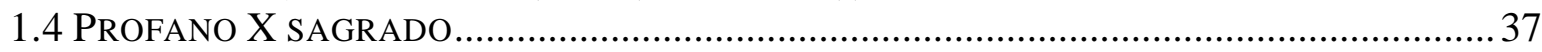

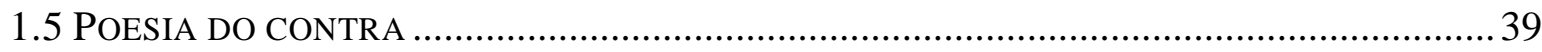

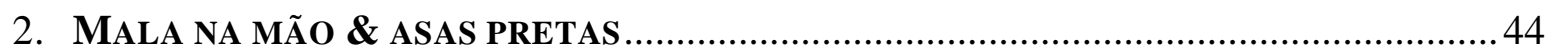

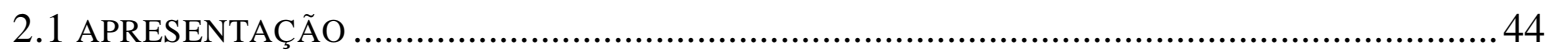

2.2 “A EPOPÉIA DO AMOR": LEITURA SEMIÓTICA DE UM POEMA DE ROBERTO PIVA..........47

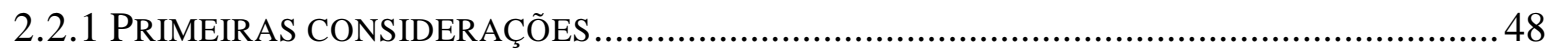

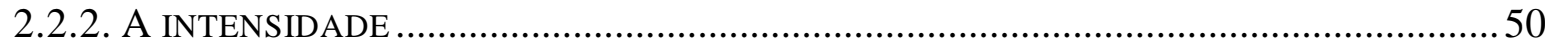

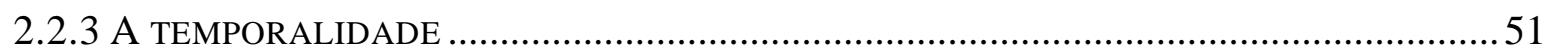

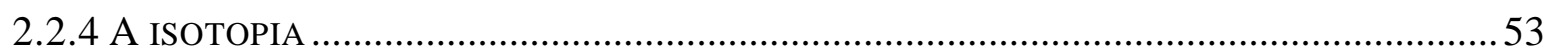

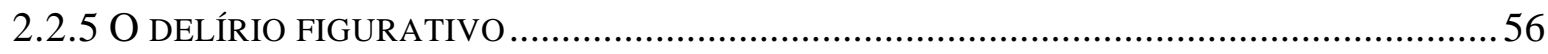

2.2.6 CONSIDERAÇÕES FINAIS SOBRE O POEMA ………….............................................5

2.3 DEVER X QUERER: ANÁLISE DE UM POEMA................................................................

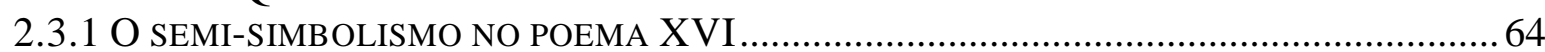

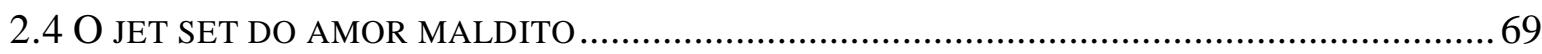

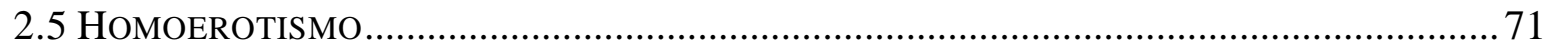

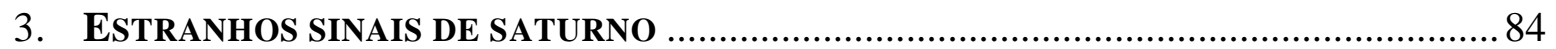

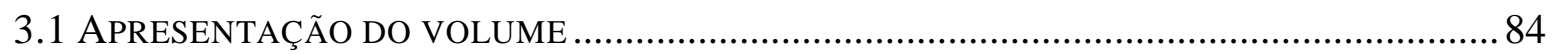

3.2 A FUNÇÃO SAGRADA DA POESIA E O XAMANISMO …………………………….......... 84

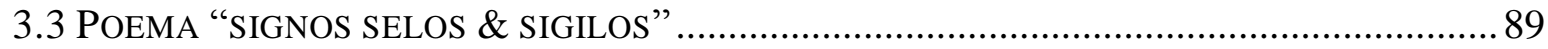

3.3.1 A SEMIÓTICA VERBAL E OS ANAGRAMAS ................................................................ 94

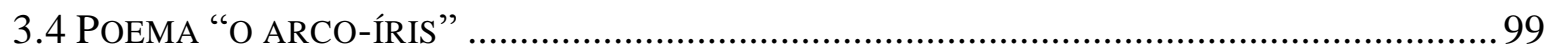

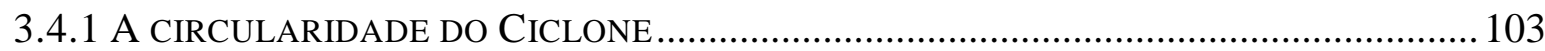

3.5 ALGUMAS CONSIDERAÇÕES SOBRE FIGURATIVIDADE.................................................. 105

3.5.1 A FigURATIVIDADE NO VOLUME ESTRANHOS SINAIS DE SATURNO ……………........ 108

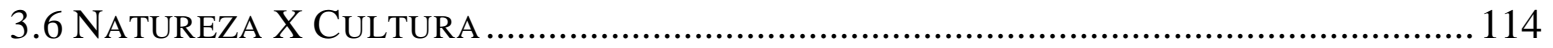

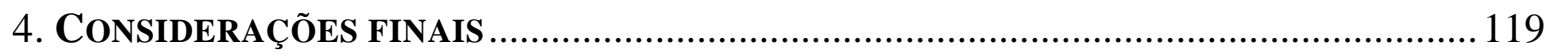

4.1 ROBERTO PIVA, UM POETA EM DESACORDO............................................................... 119

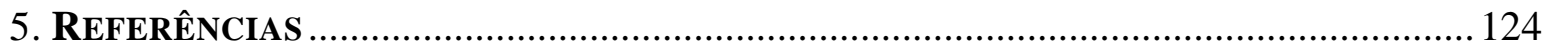




\section{INTRODUÇÃO}

\section{Considerações iniciais}

Roberto Piva foi um poeta paulistano, nascido em 25 de Janeiro de 1937 e falecido em 3 de Julho de 2010. Seus primeiros poemas foram publicados em 1961, e integrou a famosa Antologia dos Novíssimos, de Massao Ohno. Formou-se em sociologia e foi professor de história e estudos sociais. Acima de tudo, foi um poeta que acreditava no poder de libertação da poesia, e sua força perante o aprisionamento mental e corporal causado pelo controle simbólico da ideologia dominante. Seus poemas, ao longo do tempo, foram publicados em antologias e livros de pequenas tiragens, até que, em 2005, foi anunciada a publicação de três volumes com todas as obras reunidas. Em 2008, o último volume foi impresso.

Publicou, em 1963, o livro Paranoia, com as fotos de Wesley Duke Lee, que foi um sucesso de vendas e esgotou-se rapidamente, o que fez com que o poeta ganhasse certa notoriedade no circuito cultural da época. Após o sucesso de Paranoia, publicou, em 1964, o livro Piazzas, e em seguida ficou um período de cerca de 11 anos sem lançar um livro, apenas manifestos e poemas dispersos. Durante esse anos, organizou pop shows que ficaram conhecidos no circuito alternativo. Era homossexual e declarava abertamente sua preferência por meninos mais jovens, o que em plena década de 1960 causava, para dizer o mínimo, um certo escândalo.

É importante saber sobre Piva que ele sempre acreditou que a vida e a literatura deveriam estar interligadas, não de uma forma apenas a incluir os fatos biográficos na literatura, mas através de uma incorporação da literatura na vida cotidiana, para ele "a poesia é uma forma de reenergizar o planeta". Foi um poeta que acreditou extremamente no poder de criação e transformação das palavras. Dessa forma, alinhado a ideais surrealistas e 
influência dos beatniks, sua vida e sua obra estão conjugadas, como demonstrado na frase emblemática que repetia em diversas entrevistas: "Não acredito em poeta experimental que não tenha vida experimental"

Álcir Pécora, professor da Universidade de Campinas, é o organizador das obras reunidas de Roberto Piva. Segundo ele, a opção pela organização dos poemas se deu por ordem cronológica. Essa ordem, no entanto, representa um “desenho cronológico particular", pois os três "surtos de produção" representam, cada um, um momento poético diferente.

Os primeiros poemas de Piva datam da primeira metade dos anos 1960. Foi nessa época que escreveu os poemas que estão reunidos no primeiro volume da coletânea, intitulado Um Estrangeiro na Legião. O segundo volume, intitulado Mala na mão \& Asas Pretas compreende poemas escritos entre a segunda metade dos anos 1970 e o começo dos anos 1980. O terceiro volume apresenta poemas do final dos anos 1990 e dos anos 2000, e tem o título de Estranhos Sinais de Saturno. Pécora sinaliza, no prefácio do primeiro livro que, ainda que alguns traços permaneçam em todos os momentos, o conjunto de cada volume apresenta diferenças significativas.

Os poemas de Roberto Piva deixam entrever um sujeito que não está de acordo com as normas da sociedade em que vive. Ele não quer compactuar ou pertencer a essa sociedade ou de acordo com os moldes impostos por ela. A subversão, em Piva, não é apenas um tema, é parte de um projeto poético e de um modo de encarar a poesia como possibilidade de resistência à utilitarização da vida. A maior parte de seus poemas não segue formas fixas e não têm uma organização de versos previsível. Há muitas figuras - e seqüências de figuras - incompreensíveis e inimagináveis. Há poemas que fazem referências à outros poetas, filósofos, teóricos; há também poemas escatológicos, ou que 
fazem referência à loucos, bêbados, drogas e drogados; há também poemas místicos, holísticos; e também poemas de teor sexual-amoroso. A variedade dos poemas revela, no entanto, um fio condutor temático entre conjuntos de poemas e da obra, em geral.

Muito se fala da força de Piva como agitador cultural e como alguém capaz de congregar grupos, principalmente de jovens. Sobre isso, é interessante pensar no regime poético afirmado por Piva, pois os poetas se definem em relação ao regime do qual fazem parte.

\section{Regimes de interação poética}

No capítulo inicial de sua tese de livre-docência, Antonio Vicente Pietroforte, inspirado nos modelos de Floch $^{1}$, estabelece quatro regimes de realização poética, construídos a partir das categorias formais de continuidade vs descontinuidade, de acordo com o modo como se trabalha a semiótica verbal e o discurso. Esses regimes de interação são construídos através do estilo de coesão, definido como as coerções estabelecidas por um gênero discursivo na forma da expressão e do conteúdo. A poesia de um poeta se define em relação ao regime escolhido. Esses regimes são sistematizados da seguinte forma:

descontinuidade / lingüista

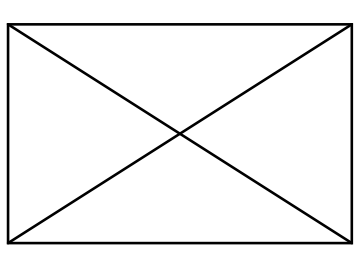

não-continuidade / arquiteto continuidade / pregador

não-descontinuidade / conversador

(PIETROFORTE, 2011: 30)

\footnotetext{
1 “Êtes-vous arpenteur ou somnambule? L'elaboration d'une typologie comportementale des voyager du mêtro" (Floch, 1995: 19-47)
} 
Não é a intenção desta breve introdução desenvolver integralmente todos os esses conceitos e seu modo de funcionamento. Contudo, é preciso assinalar, de forma, sucinta, como se dá o funcionamento de todos esses regimes para, em seguida, situar o poeta Roberto Piva. Antonio Vicente Pietroforte explica cada um desses regimes:

“Cada regime é definido por uma forma de expressão: o lingüista afirma a descontinuidade desmontando o sistema verbal; o conversador nega a descontinuidade ao respeitar o comportamento lexical sem desmontá-lo; o pregador afirma a continuidade em suas frases livres e desbragadas; e o arquiteto nega a continuidade do discurso ao impor um sistema de escansão para organizar o fluxo entoativo. Do lingüista ao pregador, passando pelo conversador, há uma deriva da poesia para a prosa; e do pregador ao lingüista, passando pelo arquiteto, há uma deriva da poesia falada para a poesia visual. O percurso orientado na afirmação da continuidade está dirigido para a prosa poética, mais afeita à continuidade da palavra e do discurso; já o percurso contrário, orientado na afirmação da descontinuidade, necessita de recursos visuais para marcar a segmentação imposta pela versificação ou pela desmontagem do léxico. Essas orientações, próprias do plano de expressão da poesia, estão correlacionadas a formas de conteúdo:

- O poeta linguista, ao insistir na desmontagem do sistema verbal, tende a trabalhar sobre conteúdos metalingüísticos, utilizando a linguagem para falar da própria linguagem, como faz Arnaldo Antunes.

- O poeta arquiteto também faz esse trabalho, mas antes de inventar novas formas, reutiliza e inova formas já consagradas, como Glauco Mattoso faz com o soneto e a literatura de cordel, e Alice Ruiz, com o haikai. 
- O poeta pregador, os insistir no fluxo discursivo, deriva para conteúdos delirantes, como fazem Roberto Piva e Jorge Mautner. Não é por acaso que tais poetas, muitas vezes, são chamados profetas, mesmo que profetas vigaristas, como Jorge Mautner insiste na construção de seu ethos.

- O poeta conversador, com versos livres, mas com coerência figurativa menos delirante, geralmente trata de temas engajados, como a maioria dos poetas de esquerda - por exemplo Ferreira Gular - e boa parte dos poetas da chamada literatura negra - por exemplo Cuti.

O negação da desconstrução da palavra encaminha o discurso da metalinguagem para a referencialização, de modo que o regime do poeta conversador é útil em engajamentos mais temáticos que metalingüísticos”(PIETROFORTE, 2011: 30-31)

\section{Roberto Piva, poeta pregador}

Roberto Piva integra o regime do pregador. Essa nomeação parece feita sob medida para o poeta, e auxilia a compreender toda a sua poesia, pois o que foi dito acima, sobre a capacidade como agitador cultural e de congregar jovens, está relacionada aos recursos discursivos de sua poesia. Dentre esses recursos está a fixação de uma frase, mas também de palavras ou de traços fonológicos que formam aliterações ou assonâncias. Essa fixação não é apenas temática, mas também entoativa, o que faz com que o poema pareça ter sido feito para ser recitado em frente a uma multidão, o que condiz perfeitamente com a própria figura e história do Piva. È um poeta que prega o desregramento: dos versos, dos sentidos, das imagens e da vida.

A afirmação da continuidade, na poesia, resulta em versos livres e longos, sem pontuação, dispostos desorganizadamente pela página, frases, palavras e sons repetidos, 
criando um tom declamativo. Essas características remetem a um espontaneísmo, algo que se realiza por si só sem causa aparente, sem ser forçado.

O poema de Roberto Piva escolhido como exemplo das características do poeta pregador é "Os anjos de Sodoma", no qual a frase "eu vi os anjos de Sodoma" funciona como tema, a partir do qual as estrofes se constroem:

Eu vi os anjos de Sodoma escalando um monte até o céu

E suas asas destruídas pelo fogo abanavam o ar da tarde

Eu vi os anjos de Sodoma semeando prodígios para a criação não perder seu ritmo de harpas

$\mathrm{Eu}$ vi os anjos de Sodoma lambendo as feridas dos que morreram sem alarde, dos suplicantes, dos suicidas e dos jovens mortos

$\mathrm{Eu}$ vi os anjos de Sodoma crescendo com o fogo e de suas bocas saltavam medusas cegas

Eu vi os anjos de Sodoma desgrenhados e violentos aniquilando os mercadores, roubando o sono das virgens, criando palavras turbulentas

Eu vi os anjos de Sodoma inventando a loucura e o arrependimento de Deus

Outros poemas também poderiam servir de exemplificação, dentro as quais os seguintes, do livro Estranhos sinais de Saturno: 
1.

Eu sou a viagem de ácido

nos barcos da noite

$\mathrm{Eu}$ sou o garoto que se masturba

na montanha

Eu sou o tecno pagão

Eu sou o Reich, Ferenczi \& Jung

Eu sou o Eterno Retorno

Eu sou o espaço cibernético

$\mathrm{Eu}$ sou a floresta virgem

das garotas convulsivas

Eu sou o disco-voador tatuado

$\mathrm{Eu}$ sou o garoto e a garota

Casa Grande \& Senzala

Eu sou a orgia com o

garoto loiro e sua namorada

de vagina colorida

(ele vestia a calcinha dela

$\&$ dançava feito Shiva

no meu corpo)

Eu sou o nômade de Orgônio

Eu sou a Ilha de Veludo

Eu sou a Invenção de Orfeu

Eu sou os olhos pescadores

Eu sou o Tambor do Xamã

(\& o Xamã coberto

de peles e andrógino)

Eu sou o beijo de Urânio

de Al Capone

Eu sou uma metralhadora em

estado de graça

Eu sou a pomba-gira do Absoluto 
2.

seja devasso

seja vulcão

seja andrógino

cavalo de Dionysos

no diamante mais precioso

O poema 2, ainda que não seja composto por versos longos, também integra o regime poético do pregador, através de características como a fixação de uma palavra que se repete, a tom declamativo e o delírio figurativo. Não é necessário, portanto, que o poema seja longo para que pertença ao regime do poeta pregador. 


\section{UM ESTRANGEIRO NA LEGIÃO}

\subsection{Considerações iniciais}

O livro em análise, Um estrangeiro na legião, será considerado como uma totalidade discursiva, na qual as partes estão diretamente entrelaçadas ao todo, constituindo uma unidade integral, na qual o ethos do sujeito é depreensível através do modo de dizer que remete a um modo de ser, que será desvendado ao longo do trabalho.

Os poemas do primeiro livro da coletânea de obras de Roberto Piva são marcados, em geral, por um sistema de oposições manifestadamente esquemático. Nesse jogo de oposições, evidentemente, um lado é euforizado e outro é disforizado. O lado euforizado é o lado que demarca valores de rebeldia (versus conformismo), liberdade (versus opressão), profano (versus sagrado), obscenidade/voluptuosidade (versus puritanismo). Nesse contexto, a rebelião, a desordem e o sexo são instrumentos de resistência ao cerco imposto à liberdade individual dos seres humanos.

Há muitos poemas que oferecem dificuldades de leitura, quer seja pela disposição desorganizada dos versos na página, pelo excesso de figuras dispares unidas sequencialmente, pelo ritmo exaltarório e declamativo sempre em ascensão e sem pausas de leitura, pela ausência de pontuação. Essa experiência de incompreensão é parte estruturante do sentido da obra, pois recusar-se ao sentido é, em si, um ato de transgressão.

Este trabalho busca, em linhas gerais, fazer uma análise do éthos e da construção identitária do primeiro volume das obras reunidas de Roberto Piva, intitulado Um estrangeiro na legião. Considerando que o ethos é a construção da identidade pelo modo de dizer, ou seja, um modo próprio de constituição do sujeito, que o situa no mundo, e que o efeito de sentido de identidade é resultado de uma isotopia de imagens de si, o trabalho a 
ser realizado buscará compreender, através da análise semiótica de alguns poemas, como se dá a construção coesa de um ethos que permeia todo o livro Um estrangeiro na legião. A esse ethos dar-se-á o nome de subversivo.

\subsection{A construção do ethos}

A noção de ethos remete, invevitavelmente, à Retórica de Aristóteles, na qual o filósofo grego buscava examinar como um orador poderia persuadir determinado público de maneira mais eficaz através da impressão que ele causava, ou seja, como este orador poderia criar uma imagem de si para seu auditório que lhe conferisse credibilidade e adesão ao seu discurso, mobilizando a afetividade do destinatário. Nesse contexto, pensava-se em tom de voz, modulação da fala, gestualidade, olhar, postura, escolha de palavras, vestimenta, dentre outros elementos que o fizessem atingir seu objetivo, a persuasão. O ethos retórico está ligado à própria enunciação, ou seja, o ato de produção do discurso, no entanto, o caráter do orador é importante na medida em que ele o mostra, sem dizê-lo. Em outras palavras, nessa visão de ethos, o caráter do enunciador não está explícito no enunciado, na sua produção textual do discurso, mas sim na própria enunciação.

A Semiótica e a Análise do Discurso valeram-se de algumas ideias do ethos aristotélico, porém há diferenças a serem consideradas. O ethos semiótico é também uma noção discursiva, se constitui por meio do discurso, portanto não é algo exterior à fala, no entanto, para as ciências que buscam estudar o sentido, o ethos deixa de ser apenas um meio de persuasão, tornando-se parte constitutiva da cena de enunciação. $O$ discurso pressupõe essa cena de enunciação para poder ser enunciado, e, por seu turno, ele deve validá-la por sua própria enunciação: qualquer discurso, por seu próprio desdobramento, pretende instituir a situação de enunciação que o torna pertinente (AMOSSY, Org, 2005: 
73). Através da análise do ethos podemos compreender melhor o sujeito discursivo como corpo sensível, e reconstruir a forma de percepção do mundo a partir da qual um discurso é estruturado.

O ethos é uma maneira de dizer, não é algo que o sujeito afirma sobre si de maneira explícita, ele é depreensível a partir do discurso desse sujeito. A recorrência desse modo de dizer constitui e afirma um modo de ser. Através da análise do ethos podemos compreender melhor esse sujeito discursivo como corpo sensível, e reconstruir a forma de percepção do mundo a partir da qual um discurso é estruturado.

Todos os poemas de Um estrangeiro na legião deixam entrever um sujeito que não está de acordo com as normas sociais da sociedade em que vive. Ele não quer compactuar ou pertencer a essa sociedade ou de acordo com os moldes impostos por ela. Como se verá ao longo desse trabalho, são diversas as características - estruturais, narrativas e discursivas - que constroem o ethos subversivo desse sujeito, marcado pelo querer não ser e por não poder ser $X$, sendo $\mathrm{X}$ entendido como um sujeito que se encaixa nessa sociedade. O corpus base para esse trabalho serão três poemas, mas outros poemas serão evocados constantemente, a fim de melhor demonstrar e exemplificar o que se fala. Os poemas escolhidos são "A piedade" e "Poema Porrada", ambos do livro Paranóia e "A máquina de matar o tempo", do livro Os que viram a carcaça.

A leitura desses três poemas evidencia um sujeito construído a partir do querer não ser e do não poder ser $X$, marcado em discurso através dos verbos modais, porém há muitos outros poemas nos quais essa marcação está no nível semântico, mas não aparece em termos de léxico.

\subsubsection{A piedade}


Eu urrava nos poliedros da Justiça meu momento abatido na extrema paliçada

os professores falavam da vontade de dominar e da luta pela vida

as senhoras católicas são piedosas

os comunistas são piedosos

os comerciantes são piedosos

só eu não sou piedoso

se eu fosse piedoso meu sexo seria dócil e só se ergueria aos

sábados à noite

eu seria um bom filho meus colegas me chamariam cu-de-ferro e me

fariam perguntas por que navio bóia? Por que prego afunda?

eu deixaria proliferar uma úlcera e admiraria as estátuas de fortes dentaduras

iria a bailes onde eu não poderia levar meus amigos pederastas ou

barbudos

eu me universalizaria no senso comum e eles diriam que tenho

todas as virtudes

eu não sou piedoso

eu nunca poderei ser piedoso

meus olhos retinem e tingem-se de verde

Os arranha-céus de carniça se decompõem nos pavimentos

Os adolescentes nas escolas bufam como cadelas asfixiadas

arcanjos de enxofre bombardeiam o horizonte através dos meus sonhos

O termo "piedade", a partir do trabalho de Eliane Soares de Lima², pode ser entendido como: sofrer por; cumprimento do dever; virtude, justiça; cumprimento dos deveres religiosos; partilha de valores; imposição social; alteridade. Essas definições mostram a piedade como um sentimento que faz parte de um dever social para com o próximo, o que implica um compartilhamento dos valores entre o sujeito piedoso e o objeto

2 "Entre enunciador e enunciatário: um estudo sobre a compaixão" 
(ou sujeito) da piedade. Em linhas gerais, é um sentimento imposto pelo discurso do bom comportamento social e religioso. Nesse sentido, ter piedade é um dever para os indivíduos que querem integrar-se na sociedade. $\mathrm{O}$ enunciador do poema quer exatamente o contrário, desintegrar-se dessas normas sociais e, portanto, de tudo que é imposto como um dever.

No poema "A piedade", denominado, de agora em diante, de poema I, é estabelecida uma oposição entre ser piedoso e não ser piedoso, ao que o enunciador "eu" afirma a negativa, em "eu não sou piedoso". Nas duas primeiras linhas do poema, o enunciador se apresenta de maneira intensa, no conteúdo, o que é marcante pelo uso do verbo "urrar", ou seja, dar um bramido forte. $\mathrm{Na}$ sequência, são apresentados diversos actantes que, a rigor, podem ser entendidos como anti-sujeitos, pois representam obstáculos ao percurso do sujeito, que quer entrar em conjunção com o valor da liberdade. No entanto, a sequência do poema mostra que, perante a força e a competência do sujeito, os antisujeitos são enfraquecidos.

No centro do poema (linhas 8 a 17), são narrados percursos narrativos possíveis de um sujeito hipotético que seria dotado dos valores de ser piedoso. Esses percursos seriam sancionados positivamente pelo destinador, como mostra o trecho "eles diriam que tenho todas as virtudes", sendo que uma das definições mais correntes de "virtudes" é "o conjunto de todas ou qualquer das boas qualidades morais ${ }^{3 \%}$. Após esse trecho, novamente o enunciador reafirma o querer não ser, que agora é intensificado de tal forma que, torna-se um não poder ser, em “eu nunca poderei ser piedoso”. É possível perceber um aumento no grau de intensidade no sentimento de aversão em relação a ser piedoso, pois enquanto o querer representa uma marca da vontade pessoal do sujeito, o não poder ser representa uma

\footnotetext{
${ }^{3}$ Dicionário Priberam de Língua Portuguesa
} 
impossibilidade total, não derivada da falta de capacidade ou vontade de $s e r$, mas sim de um sentimento de repulsa intenso.

No nível discurso, ocorre a concretização desses esquemas narrativos. A primeira palavra do poema instaura a debreagem enunciativa de pessoa: é um "eu” que enuncia seus sentimentos de contrariedade. Em seguida, são enumeradas figuras opostas ao eu que representam instâncias sociais que, aceitando os preceitos do destinador "sociedade", são piedosas. As "senhoras católicas" são a representação da igreja, os "comunistas" representam a política e os "comerciantes" representam a ordem financeira do mercado. Cada uma dessas figuras representa instituições validadas e aceitas socialmente como dotadas de um poder(fazer) e poder fazer fazer, ou seja, são pilares que compõe o destinador "sociedade".

Em seguida, através do uso dos verbos no futuro do pretérito, o enunciador dá ao seu enunciado o caráter de “antecipação imaginária”, como definida por Fiorin (2010: 160), e tem um valor hipotético. Ao enunciar fatos que poderiam ter ocorrido posteriormente a um determinado fato passado, o enunciador imagina quais as ações teria que realizar se tivesse optado por ser aderir às normas sociais e ser piedoso e que, assim, seria julgado positivamente por todos como possuidor de "todas as virtudes". Após esse trecho hipotético, o enunciador retoma os verbos no tempo presente, e reafirma que quer não ser e que, mais intensamente, não pode ser piedoso.

As quatro últimas linhas do poema constituem uma sequência de imagens construídas em delírio figurativo, na qual o efeito não é o de realidade, mas sim o de irrealidade, ou ainda, de surrealidade. Olhos tingidos de verde, arranha-céus de carniça, adolescentes bufando como cadelas e arcanjos de enxofre são imagens criadas a partir da união de figuras tão diferentes entre si que parecem, realmente, resultado de um estado de 
alucinação, no qual as imagens adentram no campo de presença do sujeito e mudam rapidamente, dando um ritmo acelerado para o conteúdo. Esse efeito de alucinação é, de fato, muito comum nos poemas de Roberto Piva.

Em termos de estruturas fundamentais, os ajustamentos do nível narrativo e discursivo se organizam sobre os valores de liberdade e opressão, sendo que a liberdade é euforizada e a opressão é disforizada pois, para o enunciador, as imposições de conduta da sociedade, gerando a recusa de seus próprios preceitos como indivíduo, é uma forma de tirania. O resultado dessas articulações resulta no seguinte quadrado semiótico:

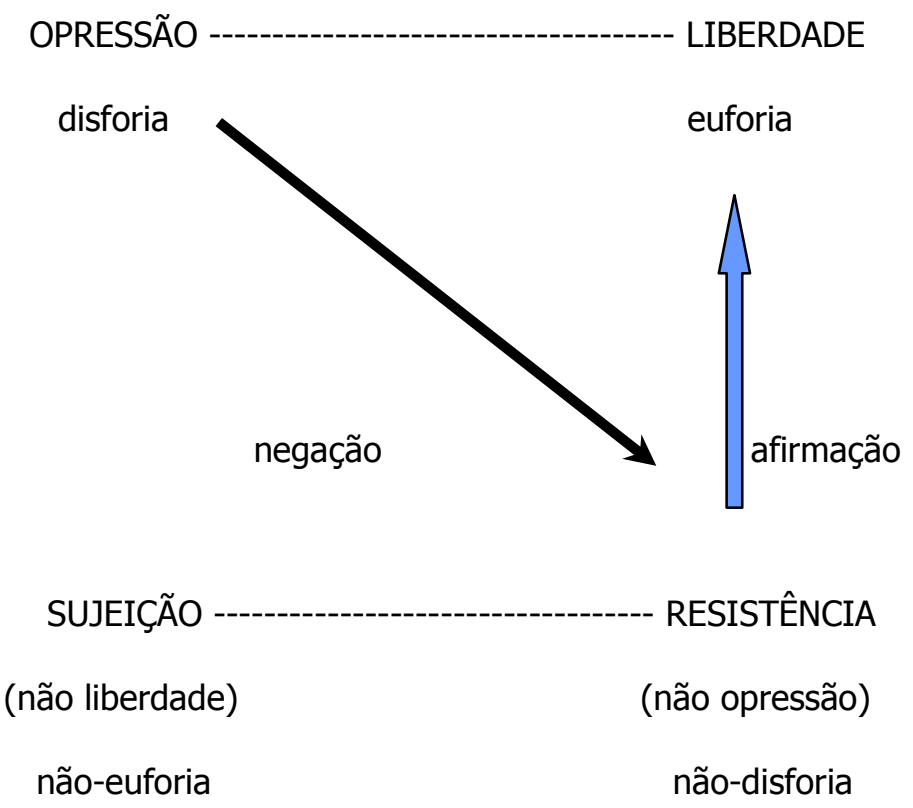

O quadrado semiótico mostra o percurso realizado no poema, que começa com a afirmação da opressão ("as senhoras católicas..."), através da demonstração dos valores do anti-sujeito, representante do destinador sociedade. Em seguida, o poema inicia seu percurso em direção à resistência, negando a opressão ("só eu não sou piedoso") e, por fim, 
afirma a liberdade ("eu não sou piedoso / eu nunca poderei ser piedoso”), negando totalmente o destinador sociedade.

\subsubsection{Interdiscursividade}

Fiorin (2003) define o texto como sendo o lugar de manifestação da língua, unidade básica de organização e transmissão de ideias, que forma um todo gerador de sentido, e o discurso é o efeito de sentido, um processo no qual os percursos temáticos e/ou figurativos de outro discurso são apropriados. Nesse sentido, um texto evoca outros textos ou remete a outros discursos. Falar sobre piedade evoca todo um discurso religioso, no qual esta é uma qualidade obrigatória para um sujeito que deseja encaixar-se na sociedade através da religião, ou seja, a "piedade" do poema traça uma interdiscursividade com o discurso cristão.

“A interdiscursividade é o processo em que se incorporam percursos temáticos e/ou percursos figurativos, temas e/ou figuras de um discurso em outro. Há dois processos interdiscursivos: a citação e a alusão" (FIORIN, 1994: 32). A citação ocorre quando um discurso repete percursos temáticos e/ou figurativos; já quando temas e/ou figuras de um discurso são colocadas servindo de contexto para a compreensão do que foi colocado temos a alusão. O poema não faz menção direta ao texto bíblico, mas evoca um tema presente em seus ensinamentos, a piedade, que tem sua importância nesse discurso enfatizada em diversos trechos, principalmente no livro de I Timóteo:

Timóteo 2

1. Exorto, pois, antes de tudo, que se façam súplicas, orações, intercessões e ações de graças por todos os homens. 
2. Pelos reis e todos os que estão em posição de autoridade, para que vivamos uma vida calma e tranqüila, em piedade e honestidade.

3. Isto é bom e agradável diante de Deus nosso Salvador.

\section{Timóteo 4}

7. Rejeita, porém, as fábulas profanas e de velhas, e exercita-te pessoalmente na piedade,

8. Porque o exercício físico é de pouca utilidade, mas a piedade para tudo é proveitosa, porque tem a promessa, tanta da vida presente como da futura.

\section{Timóteo 6}

11. Tu, porém, ó homem de Deus, foge destas coisas e em vez disso, segue a justiça, a piedade, a fé, o amor, a constância e a mansidão.

A partir desses trechos, percebe-se a relevância da piedade para a doutrina cristã, estando lado a lado com a honestidade, a fé, o amor, a constância e a mansidão. A postura e o comportamento piedoso devem ser exercitados sempre, inclusive nas orações, que são uma forma de comunicação direta com Deus, para que se tenha proveito na vida presente e na vida futura.

Como parte do projeto poético de rejeição a todos os valores que limitem ou regulem o comportamento dos homens, a poesia piviana rejeita, portanto, a piedade. No poema L'ovalle delle apparizioni, os piedosos tornam-se "estranhos embaixadores da Bondade", ressaltando ainda mais a rejeição a tudo que possa ser entendido como virtude desejável pela cultura cristã: “Eu queria ver a cara dos estranhos embaixadores da Bondade quando me / vissem passar entre as rosas de lama firmentando nas ruelas onde a Morte é tal qual uma porrada" (p. 57) e em O Volume do Grito a bondade, também parte do discurso 
presente na bíblia, é apenas uma ilusão: “capitais fora do Tempo e do Espaço e uma Sociedade Anônima / regendo a ilusão da perfeita Bondade” (p. 48-49).

\subsubsection{Poema porrada}

Eu estou farto de muita coisa

não me transformarei em subúrbio

não serei uma válvula sonora

não serei paz

eu quero a destruição de tudo que é frágil:

cristãos fábricas palácios

juízes patrões e operários

uma noite destruída cobre os dois sexos

minha alma sapateia feito louca

um tiro de máuser atravessa o tímpano de

duas centopéias

o universo é cuspido pelo cu sangrento

de um Deus-Cadela

as vísceras se comovem

eu preciso dissipar o encanto do meu velho

esqueleto

eu preciso esquecer que existo

mariposas perfuram o céu de cimento

eu me entrincheiro no Arco-Íris

Ah voltar de novo à janela

perder o olhar nos telhados como

se fossem o Universo

o girassol de Oscar Wilde entardece sobre os tetos

eu preciso partir um dia para muito longe

o mundo exterior tem pressa demais para mim

São Paulo e a Rússia não podem parar 
quando eu ia ao colégio Deus tapava os ouvidos para mim?

a Morte olha-me da parede pelos olhos apodrecidos

de Modigliani

eu gostaria de incendiar os pentelhos de Modigliani

minha alma louca aponta para a Lua

vi os professores e seus cálculos discretos ocupando

o mundo do espírito

vi criancinhas vomitando nos radiadores

vi canetas dementes hortas tampas de privada

abro os olhos as nuvens tornam-se mais duras

trago o mundo na orelha como um brinco imenso

a loucura é um espelho na manhã de pássaros sem Fôlego

O mesmo quadrado semiótico pode servir de base para a análise do "Poema Porrada", denominado, de agora em diante, de poema II, pois os mesmos valores liberdade vs opressão-, fazem emergir um percurso narrativo muito semelhante ao do poema I.

As 7 primeiras linhas do poema traçam um panorama semelhante ao anterior. Há um sujeito que afirma "estar farto de muita coisa", que em seguida enumera o que quer não ser: subúrbio, válvula sonora e paz. "Estar farto" pode ser entendido como a modalização de um não querer forte, ou de um não poder. Novamente, é um sujeito que quer não estar em conjunção com os valores que regem o "subúrbio", a "válvula sonora" e a "paz". Sequencialmente, o sujeito afirma o que quer: "eu quero a destruição de tudo que é frágil: / cristão fábricas palácios / juízes patrões e operários”. No caso do poema II, a afirmação da liberdade se dá de maneira forte logo no começo do poema.

Nos versos do meio do poema, em meio a muito delírio figurativo consideravelmente mais do que no poema I - o sujeito segue fazendo afirmações sobre o 
seu querer: "eu preciso dissipar o encanto do meu velho / esqueleto", "eu preciso esquecer que existo", "eu preciso partir um dia para muito longe" e "eu gostaria de incendiar os pentelhos de Modigliani", respectivamente. "Precisar" é um querer que beira à necessidade, portanto mais intenso, em contraposição à "gostaria”, que é um querer menos intenso. É possível perceber uma oscilação entre a relação do querer do enunciatário e a intensidade com a qual ele quer e com o que ele quer. No primeiro trecho citado, ele quer dissipar o encanto do seu esqueleto, ou seja, espalhar valores de si. Vale apontar que o que ele deseja é uma disseminação do encanto do seu esqueleto, portanto uma mistura do que é seu com os outros; essa mistura demarca um aumento no polo da extensidade do objeto do querer que, interessantemente, contrapõe-se à intensidade (querer muito) com a qual ele quer esse objeto. O sujeito quer muito espalhar-se, a princípio.

$\mathrm{Na}$ próxima manifestação do querer, essa vontade intensa muda seu foco. "Eu preciso esquecer que existo". Enquanto antes, o sujeito queria derramar-se, agora ele quer retrair-se. Na sequiência, o sujeito quer "partir um dia para muito longe", afastar-se totalmente da sociedade como espaço e como destinador. O fato de ele querer partir "um dia" insinua que talvez ele ainda não esteja totalmente dotado de suas competências para a aquisição da performance de "partir para muito longe". Diferentemente do poema I, no qual o enunciador, em nenhum momento, manifesta dúvidas sobre sua competência total e absoluta para a realização da performance, neste poema, há momentos, como esse, que deixam entrever um tom de dúvida em relação ao poder fazer. Esse momento de falta de convencimento é reforçado pelo verso seguinte: "o mundo exterior tem pressa demais para mim". No entanto, trechos como esse servem para atestar o poder do destinador sociedade, o que torna ainda maior a vontade de resistência e oposição do sujeito aos valores que lhe 
são impostos, além de exemplificarem como as incumbências desse destinador podem ser esmagadoras.

No nível discursivo, os valores do destinador sociedade, ao qual o sujeito se opõe e dos quais quer estar em disjunção, são tematizados e figurativizados. O "subúrbio" é a figura que tematiza a vida doméstica, mais precisamente dentro de uma comunidade social, na qual são necessárias adaptações, de todas as partes envolvidas, para que não haja perturbações e todos possam conviver em harmonia. A "válvula sonora" pode ser entendida como um instrumento que propaga um som de uma maneira mecânica ou automática, isso pode ser interpretado, metaforicamente, como as pressões exercidas sobre a comunicação entre as pessoas, forçadas a uma certa polidez, na qual dizer certas coisas é desautorizado. "Paz" é a tematização de todo e qualquer distúrbio ou inadequação na ordem social estabelecida. O sujeito, que renega o valor desses elementos, também os renega. E, indo ainda mais fundo, quer a “destruição de tudo que é frágil: / cristãos fábricas palácios / juízes patrões e operários". A fragilidade a que se refere o enunciador está relacionada ao fato de que a ordem social, ao reprimir manifestações de individualidade para o dito "bem estar coletivo", fica apenas no domínio do parecer, que pode ser quebrado a qualquer momento. "Cristãos fábricas palácios" são figuras da religião, do desenvolvimento (metaforicamente) e da riqueza e ostentação, respectivamente. "Juízes patrões e operários” são figuras representantes do sistema judiciário, encarregado de sancionar e penalizar as ações das pessoas e do âmbito do trabalho, o que pode mandar (poder fazer fazer) e o que deve obedecer (dever fazer).

Nesse contexto, a figura de Modigliani, quase no final do poema, é muito interessante, pois constitui uma imagem forte e chocante. O enunciador diz: "a Morte olhame da parede pelos olhos apodrecidos / de Modigliani / eu gostaria de incendiar os 
pentelhos de Modigliani”. O pintor italiano Amedeu Modiglini aparece aqui alinhado com o valor de opressão, já que, além de retratado negativamente, provoca um sentimento de raiva no enunciador. Os temas preferidos de Modigliani eram retratos e nus femininos, e o próprio pintor afirmava que suas modelos expressavam a "muda aceitação da vida". Sendo assim, é possível entender a impressão que isso causa ao enunciador, que busca, exatamente, não aceitar a vida da forma como ela é imposta pela sociedade.

O poema termina com uma imagem delirante referente à "loucura", que já havia sido evocada anteriormente. Os três trechos são os seguintes: "minha alma sapateia feito louca", "minha alma louca aponta para a Lua" e "a loucura é um espelho na manhã de pássaros sem Fôlego". No primeiro momento, a alma sapateia feito louca; no segundo momento a alma já está louca, e aponta em direção à Lua, (noite), e, por fỉm, a loucura não está mais restrita à alma, já é algo que integra um espaço (a manhã) e é definida como um “espelho". O léxico espelho pode significar "objeto de vidro ou de metal polido que reproduz nitidamente as imagens que o defrontam", mas também pode significar "coisa digna de se imitar, exemplo, modelo" ${ }^{4}$. Dentro do contexto do poema, é possível considerar o sentido metafórico do espelho como um exemplo a ser seguido. A loucura, cujos semas incluem espontaneidade nos atos, imprudência, insensatez e desvios de conduta, para esse enunciador, é uma forma de liberdade.

\subsubsection{A máquina de matar o tempo}

Aqui nós investimos contra a alma imortal dos gabinetes. Procuramos amigos que não sejam sérios: os macumbeiros, os loucos confidentes, imperadores desterrados, freiras

\footnotetext{
${ }^{4}$ Dicionário Priberam de Língua Portuguesa
} 
surdas, cafajestes com hemorróidas e todos que detestam os sonhos incolores da poesia dos Arcadas.

Nós sabemos muito bem que a ternura de lacinhos é um luxo protozoário.

Sede violentos como uma gastrite. Abaixo as borboletas douradas.

Olhai o cintilante conteúdo das latrinas.

O poema “A máquina de matar o tempo", de agora em diante denominado de poema III, é parte integrante do livro Os que viram a carcaça, uma espécie de manifestos em forma de poesia.

Em geral, no nível narrativo, o poema III é muito semelhante aos poemas anteriores, principalmente ao I. Novamente, é um sujeito que quer não ser, e não estar em conjunção com os valores do destinador sociedade, pois esses, para ele, são valores de opressão, marcados como disfóricos. No nível discursivo, há pequenas diferenças a serem sinalizadas.

O enunciador desse poema não é mais um "eu”, é um “nós”, o que implica em um conjunto de actantes que partilham dos mesmos valores e praticam as mesmas ações de oposição às imposições da ordem social. Esse enunciador múltiplo "investe contra a alma imortal dos gabinetes" e procura amigos "que não sejam sérios". Investir contra não é simplesmente opor-se a ela, é “atirar-se impetuosamente" contra isso, atacando-o, ou seja, não é apenas uma oposição no mundo das ideias, é uma ação que busca impedir a efetividade dessas imposições sociais. Para isso, o "nós” busca multiplicar-se, procurando “amigos que não sejam sérios”, já que seriedade é a conduta determinada pelo contexto do gabinete, e deve, portanto, ser combatida. Os "macumbeiros, os loucos confidentes, imperadores desterrados, freiras surdas, cafajestes com hemorróidas e todos que detestam os sonhos incolores da poesia dos Arcadas" são figuras dessa não-seriedade, que estão em 
contrariedade contra a ordem religiosa dominante, à normalidade, a lógica política, às obrigações religiosas, ao bom comportamento amoroso-sexual e à simplicidade e leveza temática, respectivamente.

Apoiando-se isotopicamente na poesia árcade, a continuação do poema critica a leveza, simplicidade e delicadeza, em favor da violência que deve emergir para sustentar as ações de oposição aos valores opressivos. O enunciador "sabe muito bem", que a "ternura de lacinhos", ou seja, esse leveza e suavidade é um "luxo protozoário", sendo que o luxo indica uma superfluidade, a ostentação de algo (para fortalecer um parecer) e o protozoário, cuja definição dicionarizada é "um animal geralmente microscópico de corpo unicelular ou formado por uma colônia de células iguais entre si” representa esse corpo social composto por elementos iguais entre si, não dotados de complexidade.

As duas últimas linhas do poema incitam à rebelião contra tudo isso. O imperativo "sede violentos como uma gastrite" reforça o que foi dito anteriormente sobre a força nascida da violência para constituir uma forma de resistência e oposição. A figura escatológica final, “o conteúdo cintilante das latrinas”, é uma forte oposição à "ternura de lacinhos".

Nesse poema, em nível fundamental, estão intrinsecamente ligados os valores de desordem, como uma forma de liberdade, e os valores da ordem, como forma de opressão. O resultado dessas articulações resulta no seguinte quadrado semiótico:

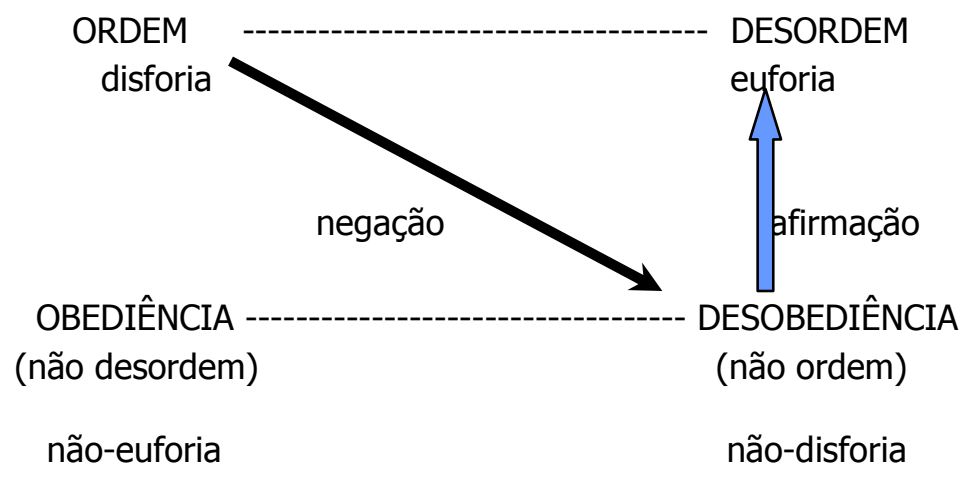


A negação da ordem está explicitada logo no começo do poema ("aqui nós investimos contra a alma imortal dos gabinetes"). Em seguida, afirma-se a desobediência, a procura de adjuvantes no projeto de oposição. Por fim, instaura-se a desordem, enfaticamente e em forma de imperativo ("Sede violentos como uma gastrite. Abaixo as borboletas douradas"). Em outro poema, "Bules, bílis e bolas", o enunciador afirma categoricamente: "Nós convidamos todos a se entregarem à dissolução e ao desregramento (...) Somos deliciosamente desorganizados e usualmente nos associamos com a Liberdade".

\subsection{Considerações sobre a (anti-)ética e a (i)moralidade em Roberto Piva}

A poesia de Roberto Piva quer questionar, reinventar e inverter os valores morais e éticos impostos pela sociedade e que, para o poeta, são opressivos e aterradores, pois causam uma padronização artificial de conduta para todos, impedindo manifestações individuais de espontaneidade em todos os campos da vida humana. Para essa poesia, a democracia não é algo positivo: ainda que um valor represente a maioria, não representa a todos.

Cada sociedade impõe, ainda que não explicitamente, algumas regras de conduta. Isso se dá através das formações ideológicas, como definido por Norma Discini ${ }^{6}$ (2005, p. 60):

Esse sistema de representações, de normas, de regras e preceitos, que procuram não só explicar a realidade como regular o comportamento dos homens, são as formações ideológicas. Esses sistemas são sociais, já que articulados por classes sociais e reúnem valores, que constroem o mundo, ao categorizá-lo. Esses sistemas são feixes de imagens das coisas e dos homens e, criados por uma ideologia dominante, sustentam-se graças às

\footnotetext{
6 "Heterogeneidade constitutiva e formações ideológicas"
} 
instituições, como escola, família, religião, e graças aos meios de comunicação em massa. Esses sistemas, internalizados como verdades universais e não como crenças criadas pelo homem, representam interesses politicos e econômicos dominantes de uma época. Assim, as formações ideológicas, ao ditar o que pensar, o que sentir, o que fazer, governam os discursos, onde se materializam por meio não apenas do recorte temático e figurativo do mundo, mas também pelo modo de usar os temas e figuras (...).

A propósito, ao ser designada a formação ideológica, fala-se em formação, porque é considerado um conjunto sistemático de ideias e valores, porque é pensado como um corpo lógico e coerente de representações; porque é reconhecido um sistema estável de interpretações; porque são lembradas regularidades de procedimentos; porque é concebido um conjunto organizado de prescrições e normas, conjunto que dita deveres, quereres, poderes e saberes a indivíduos, assim arrebanhados e assujeitados pelos interesses das 'classes sociais em conflito umas com as outras'.

As formações ideológicas regulam os modos de pensar, agir e fazer, constituindo, a partir disso, conjuntos de prescrições e interdições. Uma formação ideológica impõe ideias e valores considerados desejáveis ou obrigatórios, ao mesmo tempo em que impõe os valores indesejáveis, insatisfatórios ou inaceitáveis.

A poesia de Roberto Piva faz um questionamento das ideias e valores que constituem a ideologia dominante de seu tempo. Nesse sentido, tudo que é tido como pertencente à "moral e aos bons costumes" é sempre disforizado e fruto de questionamento e de repulsa.

Nos poemas de Um estrangeiro na legião, o sujeito tem uma imagem de si construída para representá-lo, ou seja, é a representação que ele transmite no modo do 
parecer, podendo ou não serem confirmadas de modo veridictório pelo ser. O sujeito sabe que essa imagem de si está em desacordo com as regras de convívio em sociedade, que visa o apagamento de alguns traços, em favor de um ajustamento nesse espaço. O sujeito recusa essa regulação, opondo-se a seus valores e ações, e busca encontrar um outro grupo social, com integrantes que, assim como ele, estão em desajuste com as normas.

Sobre a ética e a moral, Elizabeth Harkot-de-La-Taille \& Yves de La Taille ${ }^{7}$ dizem estar de acordo com o seguinte : "A diferenciação usualmente feita entre moral e ética consiste em reservar a primeira para designar um conjunto de regras que regem a convivência social e a segunda para nomear o trabalho de reflexão sobre os princípios e fundamentos dessas regras. A moral incide sobre a dimensão das leis e do dever de cada um de obedecê-las, e a ética incide sobre as razões que legitimam a referida obediência.

Assim definidas, compreende-se que a ética antecede, do ponto de vista lógico, a moral, pois é ela que pode lhe conferir sentido. A moral responde à pergunta 'como devo agir?' e a ética responde à indagação 'por que devo agir assim? (...) A pergunta ética 'que vida eu quero viver?' implica outra: 'quem eu quero ser?'. Com efeito, escolher projetos de vida implica um envolvimento identitário” (SOUZA, Org. 2004: 69).

O trabalho poético de Piva consiste em questionar e subverter as regras morais de conduta social, e instaurar uma lógica ética através da qual essa subversão seja não só possível, como necessária. Questionar a moral é questionar, pois, os deveres impostos por ela. A questão colocada pelo sujeito piviano é por quê todas as pessoas deveriam basear seu modo de vida, sua existência, no modo de vida da maioria? Ora, não é um questionamento banal. Enquanto as regras sociais impõem um dever ser - um não poder não ser, esse sujeito

\footnotetext{
7 "A construção ética e moral de si mesmo"
} 
quer não ser. Se pensarmos que, nesse contexto, a imposição da sociedade é que o sujeito deve ser X, o sujeito dos poemas de Roberto Piva quer, defitivamente, ser Y.

A moral possui uma dimensão coletiva, por definição, tendo em vista que é a normatização de condutas sociais. Se ao sujeito, o seu querer ser não tiver essa dimensão, a moral deixa de existir, de acordo com o texto referido. Por esse motivo, escolheu-se a adoção do termo "imoral", com o "i" entre parênteses, no título dessas reflexões, para demarcar precisamente essa diferença, assim como optou-se por "anti-ética", com o prefixo também entre parênteses, para determinar a distinção entre a ética pensada através da sua dimensão coletiva.

A coletividade, em Piva, é a coletividade das minorias, insurgentes contra os valores sociais e morais legitimados pela maioria. Esse grupo inclui pederastas, barbudos, macumbeiros, loucos confidentes, imperaradores desterrados, freiras surdas, cafagestes com hemorróidas, putas, meninos visionários, bêbados, amantes e muitas outras figuras vistas "com maus olhos" pela sociedade. Esse grupo estabelece a imoralidade como ordem legítima, o que implica que, para eles, o destinador sociedade é praticamente um antisujeito, e eles adotam os valores de um anti-destinador, que os incita a ações subversivas e as sanciona positivamente. Nesse sentido, ainda que a sociedade não tenha uma boa imagem desses sujeitos, a legitimação da sua imagem se dá pelo dentre desse grupo e é, portanto, positiva. Em outras palavras, a construção das imagens de si destes sujeitos é imoral, anti-ética, e mesmo assim, positiva. Sentimentos como orgulho ou vergonha estão sujeitos ao julgamento dos membros pertencentes a esse grupo, e não à sociedade.

Estabelecer um destinador oposto ao da sociedade moral, ou seja, um antidestinador, implica em percursos de ação motivados por valores diferentes. Para que uma 
sanção seja positiva para esse grupo marginal, ela deve ser negativa para a sociedade. Portanto, as sanções positivas da sociedade são negativadas por esse grupo "marginalizado".

\subsection{Profano X sagrado}

A Igreja Católica, representante maior do cristianismo, exerceu um grande poder na construção das sociedades contemporâneas, pois sempre atuou diretamente na formação dos indivíduos, através de escolas, faculdades, programas sociais, hospitais e instituições de caridade. Baseada na Bíblia, a igreja elaborou uma doutrina a ser seguida, uma forma de vida regida por obrigações e por interdições; logo, os indivíduos que buscam a salvação espiritual devem seguir suas normas e rejeitar comportamentos que o afastem dos ensinamentos cristãos. Não cabe aqui uma discussão pormenorizada dos ensinamentos religiosos cristãos, vale dizer, no entanto, que a piedade é um dos valores pregados pela Igreja Católica, sendo assim, uma pessoa que tenha aderido a esse discurso, entra em uma relação de não poder não ser piedoso.

As figuras que compõe o imaginário da Igreja Católica aparecem na obra de Roberto Piva de forma profana, muitas vezes associadas a figuras opostas ao sagrado, ou de forma a constituírem uma cena inesperada, inusitada e irreverente. Abaixo estão exemplos do livro Um estrangeiro na legião, do uso não-sagrado das figuras da Igreja Católica:

1. “Catedrais sem Deus” (Visão 1961, p. 31),

2. "meninos prodígios eram seviciados pela Alma / ausente do Criador" (Poema Submerso, p. 35),

3. "Cristo roubando a caixa dos milagres" (Visão de São Paulo à Noite Poema Antropófago sob Narcótico, p. 39), 
4. "Delirium Tremens diante do Paraíso bundas glabras sexos de papel / anjos deitados nos canteiros cobertos de cal” ( Praça da República dos meus sonhos, p. 43),

5. "A Virgem lava sua bunda imaculada na pia batismal" (Poema de ninar para mim e Bruegel, p. 44),

6. “o Espírito Puro vomita um aplauso antiaéreo" (idem),

7. “a Virgem assassinada num bordel” (idem),

8. "Deus suicidou-se com uma navalha espanhola / os braços caem / os olhos caem / os sexos caem" (idem),

9. "onde está tua alma sempre que o velho Anjo conquista as árvores com seu sêmen?” (Rua das Palmeiras, p. 59),

10. "contra os arcanjos pelos querubins homossexuais" (A catedral da desordem, p. 141).

Marilena Chauí define a ideologia como um conjunto lógico, sistemático e coerente de representações (ideias e valores) e de normas ou regras (de conduta) que indicam e prescrevem aos membros da sociedade o que devem pensar e como devem pensar, o que devem valorizar e como devem valorizar, o que devem sentir e como devem sentir, o que devem fazer e como devem fazer (CHAUÍ, 1984: 113). Esse conceito de ideologia para a filosofia segue as mesmas ideias já apresentadas sobre formações ideológicas; o trecho de Chauí explicita o caráter normativo e impositivo da ideologia, focado no dever.

A Igreja é uma instituição social que, através das formações ideológicas, propõe normas comportamentais a serem seguidas e outras a serem rejeitadas. As interdições propostas pela Igreja incidem não só sobre o comportamento social, ou seja, do indivíduo como pertencente a um grupo, mas também muito fortemente sobre o comportamento 
pessoal e íntimo das pessoas. Em termos modais, além de regular o “dever ser” e o “dever fazer”, a igreja impõe um “dever querer”.

Por ser a formação ideológica construída na e pela linguagem, para desconstruir o seu poder, é necessário usar ferramentas da própria linguagem, nesse caso, as figuras. Assim sendo, as figuras sagradas da Igreja - Deus, Cristo, Paraíso, anjos, a Virgem, alma, Criador, o Espírito, os arcanjos e os querubins - devem ganhar um novo sentido, através da dissolução do seu traço /sacralidade/. Os anjos, querubins, a Virgem e Cristo ganham uma corporalidade humana (trechos 4, 6 e 8), são associadas a desonestidade (trecho 1), a sexualidade exacerbada (trechos 5, 7, 9 e 10), e Deus, ou Criador, perde a onipresença (trechos 1 e 2).

\subsection{Poesia do contra}

O conjunto de manifestos "Os que viram a carcaça” evidencia textualmente a opção da poesia de Roberto Piva de colocar-se contra os valores impostos pela sociedade. Neles, é possível perceber a veemência com a qual o sujeito poético ataca a ordem social e econômica da sociedade paulistana dos anos 1960. Nesses manifestos, o caráter de poeta pregador fica evidente, assim como o descontentamento com a estrutura de valores que alicerça essa sociedade. O primeiro manifesto é o seguinte

\section{O Minotauro dos minutos}

Os pontos cardeais dos nossos elementos são: a traição, a não-compreensão da utilidade das vidraças, a violência montanha-russa do Totem, o rompimento com os labirintos e nervuras do penico estreito da Lógica, contra o vosso êxtase açucarado, vós como os cães sentis necessidade do infinito, nós o curto-circuito, a escuridão e o choque somos contra a 
mensagem lírica do Mimo, contra as lantejoulas pelos caracóis, contra a vagina pelo ânus, contra os espectros pelos fantasmas, contra as escadas pelas ferrovias, contra Eliot pelo Marquês de Sade, contra a polenta pelo ragu, nós estamos perfeitamente esquizofrênicos, paranoicamente cientes de que devemos nos afastar da Bandeira das Treze Listas cujos representantes são as bordadeiras de poesia que estão espalhadas por toda a cidade.

O manifesto é quase inteiramente composto na contraposição de elementos diferentes. O sujeito quer a escuridão, o choque, o curto-circuito, ou seja, ele reitera o que os poemas analisados anteriormente já afirmaram. No entanto, esse manifesto abre uma nova possibilidade de explicar mais características relevantes na poesia de Roberto Piva, a partir do conceito de intertextualidade.

Mikhail Bakhtin, filósofo russo e estudioso da linguagem, propôs que um discurso se compõe por diversas vozes, e seu sentido se constrói na relação entre diferentes discursos. O texto é a unidade de manifestação de um discurso. A intertextualidade, nesse sentido, é o processo de incorporação de um texto em outro, seja para reproduzir o sentido incorporado, seja para transformá-lo. Há de haver três processos de intertextualidade: a citação, a alusão e a estilização. (FIORIN, 1994: 30). A citação pode confirmar ou modificar o sentido do texto citado; a alusão reproduz as construções sintáticas em que determinadas figuras são substituídas por outras, mas não cita as palavras (e/ou personagens, no caso dos filmes); a estilização é a reprodução do estilo - conjunto de recorrências formais - de outrem (FIORIN, 1994: 30-31).

Questões sobre a cidade de São Paulo e poesia podem ser levantadas a partir do intertexto criado com o poema de Guilherme de Almeida "Nossa bandeira". 
Bandeira de minha terra,

bandeira das treze listas:

são treze lanças de guerra

cercando o chão dos Paulistas!

Prece alternada, responso

entre a cor branca e a cor preta:

velas de Martim Afonso, sotaina do Padre Anchieta!

Bandeira de Bandeirantes,

branca e rota de tal sorte,

que entre os rasgões tremulantes

mostrou a sombra da morte.

Riscos negros sobre a prata:

são como o rastro sombrio

que na água deixava a chata

das Monções, subindo o rio.

Página branca - pautada

Por Deus numa hora suprema,

para que, um dia, uma espada

sobre ela escrevesse um poema:

Poema do nosso orgulho

(eu me vibro quando me lembro)

que vai de nove de julho

a vinte e oito de setembro!

Mapa de pátria guerreira

traçado pela Vitória:

cada lista é uma trincheira;

cada trincheira é uma glória!
Tiras retas, firmes: quando

o inimigo surge à frente, são barras de aço guardando nossa terra e nossa gente.

São os dois rápidos brilhos

do trem de ferro que passa:

faixa negra dos seus trilhos, faixa branca da fumaça.

Fuligem das oficinas;

cal que as cidades empoa;

fumo negro das usinas

estirado na garoa!

Linhas que avançam; há nelas, correndo num mesmo fito,

o impulso das paralelas

que procuram o infinito.

Desfile de operários;

é o cafezal alinhado;

são filas de voluntários;

são sulcos do nosso arado!

Bandeira que é o nosso espelho!

Bandeira que é a nossa pista!

Que traz, no topo vermelho,

o coração do Paulista! 
"Nossa bandeira" apresenta um esquema organizado de versos, em versos de 7 sílabas, em redondilha menor, a chamada medida velha, as estrofes são compostas por quadras com esquema de rima ABAB. O poema exalta a história da cidade de São Paulo, marcada por lutas, pelo trabalho e pelo esforço das pessoas para a grandiosidade.

O manifesto "O Minotauro dos minutos" faz uma citação do texto de Guilherme de Almeida com o intuito não de confirmar o sentido desse texto, mas de modificá-lo e recusar não só o seu significado, mas também a sua forma poética.

Foi explicado anteriormente que as formações ideológicas são representações, de normas, de regras e preceitos que buscam regular $-\mathrm{e}$, portanto restringir $-\mathrm{o}$ comportamento do homem em sociedade. Essas representações, que embasam as formações ideológicas, são simbólicas, ou seja, "resultam de operações conceituais próprias ao homem, tido como sujeito linguageiro; sujeito feito na e pela linguagem" (DISCINI, 2005: 60). As formações ideológicas não refletem visões de mundo individuais nem universais, mas sim de classes sociais dominantes, pois são elas que possuem o poder econômico e "aparato simbólico" para impor sua maneira de pensar e agir.

"Essas representações, resultando da capacidade simbólica inerente à capacidade de pensar, orientam e categorizam o mundo, reproduzindo ideias e valores que, propugnados culturalmente, constroem o que parece que há. Essas representações, repetimos, são dadas na e pela linguagem, atributo humano. Benveniste, ao discorrer sobre o poder fundador da linguagem, para destacar o elo entre o homem, a língua e a cultura, assim se expressa:

O fato de existir semelhante sistema de símbolos revela-nos um dos dados essenciais, talvez o mais profundo, da condição humana: o de que não há relação natural, imediata e direta entre o homem e o mundo, nem entre o homem e o homem. É preciso haver um intermediário, esse aparato simbólico, que tornou possiveis o pensamento e a 
linguagem. Fora da esfera biológica, a capacidade simbólica é a capacidade mais específica do ser humana. (DISCINI, 2005: 61).

A linguagem é o instrumento através do qual as formações ideológicas são criadas e validadas na sociedade, portanto, não é pouco o seu poder. Como a Lingüística propõe, uma língua não fala da realidade, de algo que se encontra no mundo, mas sim cria a realidade, a partir do momento que a nomeia, categorizando, organizando e interpretando o mundo.

A poesia de Roberto Piva busca a liberdade através da linguagem, pois se o aprisionamento é construído e se dá pela linguagem, é ela também que tem o poder de construir a liberdade, por isso que "devemos nos afastar da Bandeira das Treze Listas cujos representantes / são as bordadeiras de poesia que estão espalhadas por toda a cidade", pois para criar novas formas de representação do mundo, devem-se adotar novas formas de uso da língua. As "bordadeiras de poesia" são os poetas que estão presos em formas, em preceitos, em conceitos teóricos, fazendo um trabalho repetitivo de ornamentação e que possibilita poucas formas de variação. Da mesma forma que um sujeito, como indivíduo, não deve seguir regras fixas, a poesia também não deve. Para Roberto Piva, o caminho da subversão era a poesia: O objetivo de toda Poesia \& de toda Obra de Arte foi sempre uma mensagem de Libertação Total dos Seres Humanos escravizados pelo masoquismo moral dos Preconceitos, dos Tabus, das Leis a serviço de uma classe dominante cuja obediência leva-nos preguiçosamente a conceber a Sociedade como uma Máquina que decide quem é normal \& quem é anormal. (posfácio de Piazzas). 


\section{MALA NA MÃo \& ASAS PRETAS}

\subsection{Apresentação}

Para Roberto Piva, a poesia era parte de um projeto de subversão da sociedade e da realidade. A transgressão não é apenas um tema, é parte de um projeto poético e de um modo de encarar a poesia como possibilidade de resistência à utilitarização da vida. O sexo, a rebeldia, o profano, a violência, a alucinação e a liberdade no campo da linguagem são elementos estruturantes desse projeto, que abarca poemas datados dos anos 1960 até o começo dos anos 2000.

Mala na mão \& Asas Pretas compreende poemas escritos entre a segunda metade dos anos 1970 e o começo dos anos 1980, nos livros Abra os Olhos \& diga Ah!, Coxas sex fiction \& delírios, 20 poemas com brócoli, Quizumba e O século XXI me dará razão. Nesses livros, os limites entre poesia e prosa nem sempre são claros, o amor, o desejo e o sexo são temas constantes, a metrópole é o espaço privilegiado e a opção pela vida noturna é evidente.

Pouco se tem escrito sobre as obras reunidas no volume 2, Mala na mão \& asas pretas. Aliás, em geral, pouco se tem escrito sobre a obra de Roberto Piva, porém, quando as atenções se voltam para seus poemas, o maior destaque é, sem dúvida, o livro Paranoia, possivelmente por haver uma parceria entre poesia e artes plásticas e por sua linguagem bastante impactante. As obras do volume 1, Um estrangeiro na legião, no qual está inserido o Paranoia, apresentam uma linguagem grandiloquente, imagens e figuras chocantes, um embate forte entre um sujeito deslocado da sociedade em que se encontra. Nesse sentido, Um estrangeiro na legião aproxima-se da geração beat americana, principalmente do poeta 
Allen Ginsberg. O livro Piazzas também está neste volume e é seu livro mais bem acabado, como o próprio Piva afirma, em entrevista sobre 20 poemas com brócoli: "Esse é talvez, depois de Piazzas, meu livro mais bem acabado" (COHN, Org. 2009: 65)

As obras do volume 2 são mais difíceis de serem situadas. Há uma temática sexual forte, no qual o sexo é, além de uma fonte de prazer, um instrumento de enfrentamento político, ao ser inserido em um contexto de subversão e liberdade, pois se trata não só do sexo homossexual, mas também entre amigos, grupal, em locais públicos e de homens maduros com meninos, enfim, é uma abordagem do sexo que se compara ao Marquês de Sade. Possivelmente essa temática, considerada polêmica, afastou a poesia desse volume da crítica, pois há mais referência ao manifesto "O século XXI me dará razão", último livro do volume 2 do que dos demais livros presentes. Entrevistas dirigidas a Roberto Piva pouco perguntam sobre os livros Abra os olhos \& diga Ah!, Coxas, 20 poemas com brócoli e Quizumba, como se percebe no livro Encontros Roberto Piva (2009) ou Os dentes da memória (2011).

A entrevista feita por Carlos Von Schmidt a Roberto Piva, encontrada no livro Encontros Roberto Piva (2009), intitulada “Amor, loucura, drogas", publicada originalmente na revista artes, em Outubro de 1985, apresenta algumas palavras do poeta sobre os livros citados acima:

Abra os olhos e diga ah! "aparece uma antropofagia urbana, um momento e ruptura. Inclusive é um estilo diferente de poesia, com cortes cinematográficos, de pequenos flashes, de um universo que corre com muita velocidade. Ele retoma essa velocidade em Piazzas, mas com uma temática diferente, que é a temática da solidão dentro do amor” (p. 
Coxas é "um livro rapsódico, é um livro de um embalo de toda uma experiência catastrófica, de todo um processo de mutilação da cultura... que se viu durante esses anos de governo de direita. Que não é muito diferente de um governo de esquerda. A diferença é que a direita não fuzila em massa. Veja quantas pessoas estão em campos de concentração no Paraguai e quantas em campos de concentração em Cuba. Tem até um presídio em Cuba chamado Liberdade. Puro Orwell. Então o Coxas foi essa viagem no absurdo da América Latina. $\mathrm{O}$ absurdo que estava se vivendo naquele momento em toda a América Latina, toda aquela repressão de esquerda, de direita, de centro, de TFP, de Hare Krishna. Toda essa tentativa de normatividade, de transformar as pessoas em 'normais', foi transposta para Coxas em forma de delírio. É um livro não tanto de poesia mas de delírio que surgiu através do livro A América e as civilizações, de Darcy Ribeiro (...)" (p. 64)

20 poemas com brócolis: "Esse é talvez, depois de Piazzas, meu livro mais bem acabado. Ele foi vivenciado durante 1978-79, a partir de uma sauna da periferia, lá de Vila Matilde (...)"(p. 65)

"São poemas curtos em que mentalizo, em nível de historiografia inconsciente, aquilo tudo. Era uma sauna de grande alegria. Parecia o Império Romano, estavam lá aqueles efebos, passavam deslizando, com aquela toalha só na cintura, lindíssimos, belíssimos, verdadeiros Ganimedes. (...) Teve de tudo naquela época. Então, numa manhã mágica, tomando chope num bar da rua Tutóia, escrevi de enfiada uns 15 poemas. Depois, na outra manhã, emendando aquele fogo, escrevi os cinco restantes”. (p. 65) 
Quizumba "é também a história de um amor, um livro em que repenso as experiências com ácido, com drogas pesadas dos anos 70 (...)” (p. 66).

A palavra quizumba quer dizer "é confusão, é o grande caos, o grande atropelo de tudo. Aliás, a minha vida tem sido uma quizumba, uma anarquia permanente. Eu não fico vivendo que nem um anarquista clássico, (tom irônico) o anarquismo de sindicato. Anarquia é dia-a-dia, anarquia é todo dia. É viver uma experiência anarquista do cotidiano" (p. 67).

\subsection{A “epopeia do amor": leitura semiótica de um poema}

No presente estudo, propomos, através da análise do texto selecionado, tecer considerações sobre as características recorrentes no conjunto de poemas de Mala na mão \& asas pretas, que constituem um discurso poético. Vejamos o poema, transcrito como no livro:

(A EPOPÉIA DO AMOR COMEÇA NA CAMA COM OS LENÇÓIS

DESARRUMADOS FEITO UM CAMPO DE BATALHA)

é ali que eu começo a nascer para a madrugada \& suas

vertigens onde você meu amor se enrosca em

meu coração paranóico de veludo verde $\&$ as delícias de continentes

alaranjados dormem em seu rosto de pérolas turvas oh tambores do amor

sem parar rumo às tempestades PLANETÁRIAS \& suas

cachoeiras tristes \& pesadas como lágrimas

gosto de gostar \& a tv da alma amanhece bêbada \& tenta

dizer alguma coisa 
Esse é o décimo poema do livro Abra os olhos \& diga Ah! que, por sua vez, é o primeiro livro da coletânea. A disposição desorganizada dos versos no espaço da folha, as palavras, versos ou trechos escritos com letras maiúsculas, alternando com o uso exclusivo de minúsculas, a ausência de vírgulas e pontuação e o uso de parênteses são características de todos os poemas desse livro.

\subsubsection{Primeiras considerações}

O lexema "epopéia" carrega em si a ideia tanto de acontecimentos grandiosos, quanto da narração desses acontecimentos através da linguagem. Além disso, ao gênero epopéia está associada o tema da guerra, reiterado pela imagem do "campo de batalha". Nesse sentido, os dois primeiros versos carregam em si a ideia do amor como um acontecimento, gerado por um embate, entendido como um "choque (em que há ímpeto ou

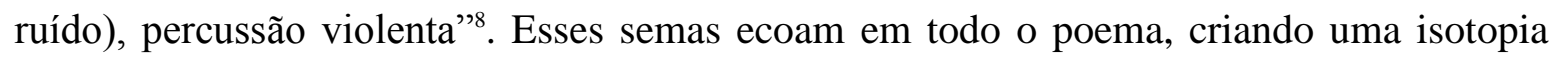
temática do embate erótico amoroso, no nível da semântica discursiva.

O "amor", em sua complexidade, é composto por muitos semas possíveis, o que permite que diferentes percursos temáticos possam ser derivados desses semas. Por isso, no caso desse poema, o amor pode ser considerado não como um tema, mas como uma configuração discursiva, nos termos de Fiorin (FIORIN, 2006: 107). Sobre o estudo de diferentes discursos que abordam o mesmo tema, mas de maneira distinta, ele afirma que uma observação atenta pode revelar que os percursos temáticos e figurativos que revestem esse tema podem ser diferentes, e que isso também é possível dentro de um mesmo discurso. Esse tipo de tema amplo que permite esse tipo de variação não seria um tema

\footnotetext{
8 Dicionário Priberam de Língua Portuguesa
} 
propriamente dito, mas uma configuração discursiva. Fiorin exemplifica essa operação (FIORIN, 2006: 111-112) através exatamente da configuração discursiva do amor, em $O$ Guarani, de José de Alencar, no qual diferentes percursos temáticos são depreensíveis: o da afeição, da sexualidade e da devoção.

Diferentes percursos temáticos do amor estão presentes no poema: o /prazer/, a /afeição/, a /turbulência/ e a /tristeza/. A associação de temas e figuras se dá, respectivamente, da seguinte forma:

(i) prazer - cama, delícias, lençóis desarrumados

(ii) afeição - meu amor, coração, gostar

(iii) turbulência - lençóis desarrumados, campo de batalha, vertigens, tambores, tempestades, bêbada

(iv) tristeza - cachoeiras tristes, lágrimas

O poema narra uma transformação. No estágio inicial o "eu” começa a "nascer para a madrugada e suas vertigens" e, ao final do poema "a tv da alma amanhece bêbada e tenta dizer alguma coisa". O nascimento para a madrugada constitui um acontecimento tão dotado de intensidade para o "eu" que, ao final do processo, no amanhecer, ele ainda encontra-se em estado de embriaguez, de não-compreensão, e não consegue formular o que lhe aconteceu, tentando, sem sucesso, “dizer alguma coisa”. O amor não está representado de forma idealizada, tanto que o sofrimento que o amor pode gerar, a tristeza, também é evocado no poema, sem ser, no entanto, disforizado, pois o sujeito adota como positivo o amor como um todo, em todas as suas representações. 
As figuras e temas da semântica discursiva estão representando valores de liberdade (versus valores de opressão). As imagens, figurativas ou temáticas, relacionadas ao amor e ao sexo, portanto, estão ancoradas nessa relação fundamental.

\subsubsection{A intensidade}

Os dois primeiros versos, tanto no plano da expressão quanto no plano do conteúdo causam um impacto, que é resultado de uma tonicidade forte e de um andamento acelerado. Esse impacto é causado, na expressão, pelo uso das letras maiúsculas e pela ausência de pontuação, que cria um ritmo rápido e, no conteúdo, por imagens fortes como a “epopéia do amor", os "lençóis desarrumados" e o "campo de batalha". Esses versos funcionam como um título e sua ressonância é percebida ao longo do poema todo. A "cama” é o espaço fundador desse encontro sexual e desse novo estado do sujeito, como é reiterado no verso seguinte, através do dêitico “ali”, é através de uma ação ocorrida na cama que o sujeito começa a "nascer para a madrugada". A cama é um espaço tematizado, representativo do valor de liberdade. É um espaço fechado, não público, o que representa uma diferença em relação a parte maior do conjuntos dos poemas do livro, nos quais o espaço público, seja ele aberto ou fechado, é o fundador de uma mudança no estado do sujeito. No que diz respeito a diferenças em relação ao discurso geral do livro, esse poema também é uma exceção pelo fato de não propor um embate a outras instâncias sociais e não explicitar o amor erótico como homossexual, o que é demarcado discursivamente na grande maioria dos poemas.

$\mathrm{O}$ ato erótico é tão marcado pela intensidade que inspira o sujeito ao delírio. $\mathrm{O}$ andamento acelerado e a tonicidade alta deixam o sujeito em um estado sensível tão forte que o resultado é o delírio, mais precisamente o delírio figurativo, presente em todo o 
poema, mas mais evidentemente marcado nos versos 5 e 6 , causando um efeito de alucinação.

No plano fonético-fonológico, a intensidade do conteúdo, nos dois primeiros versos, está correlacionada, no nível da expressão, ainda, ao predomínio das consoantes oclusivas surdas /p/ e /k/, principalmente, e sonoras /b/ e /d/, em menor ocorrência, juntamente com a escolha evidente pelas vogais altas /a/ e /o/.

\subsubsection{A temporalidade}

Nos dois primeiros versos, embora não haja primeira pessoa, o tempo no presente sugere uma debreagem enunciativa, mas cuja primeira pessoa só se explicita no terceiro verso do poema. Nesses dois primeiros versos, ainda que estejam em debreagem enunciativa, a não manifestação explícita da primeira pessoa parece gerar o efeito de sentido de objetividade. Esse efeito de objetividade dos dois primeiros versos serve para criar a sensação de veracidade do que se afirma, e funciona como a tese que será defendida pelo poema. O advérbio de lugar "ali” é enunciativo, e retoma um espaço escrito no enunciado anteriormente ("a cama").

Em relação aos verbos, o poema tem os seguintes:

(i) começa (linha 1)

(ii) começo (linha 3)

(iii) nascer (linha 4)

(iv) se enrosca (linha 4)

(v) dormem (linha 6)

(vi) gostar (linha 9) 
(vii) amanhece (linha 9)

(viii) tenta dizer (locução verbal - linhas 9/10)

Esse pequeno número de verbos ilustra que o foco do poema não são ações, mas sim estados. São verbos no tempo presente do indicativo ou no infinitivo. Os verbos no presente, em geral, apontam uma concomitância do fato narrado ao momento de enunciação, porém esse não parece ser o caso aqui. $\mathrm{O}$ aspecto verbal indica um processo de duração contínua, como se a ideia de sempre estivesse subentendida em relação aos acontecimentos. Nos termos de Fiorin (2010: 151), isso é chamado de presente omnitemporal ou gnômico, quando o momento de referência é ilimitado e, portanto, também o é o momento do acontecimento. É um tipo de uso do presente que pretende enunciar verdades eternas ou que podem ser entendidas como tais.

A temporalidade criada aqui indica a "fantasia de um tempo eterno", como apontado por Eliane Robert Moraes, no posfácio do livro. Ela diz o seguinte: “a temporalidade fundada no sexo promove sem cessar o retorno a um presente que só responde ao princípio do prazer e, por isso mesmo, já não se inscreve na história nem na própria duração temporal”. Em outras palavras, o tempo fundado não é mensurável cronologicamente, pois indica o começo de uma mudança do estado total do sujeito, uma transformação que se constrói constantemente através do tempo e não tem um final demarcado, não é um estado passageiro. Em outro poema do livro, intitulado Bar Cazzo d'Oro, diz-se "o relógio que bate as paixões delira”.

A conjunção com valores de liberdade, nos poemas de Roberto Piva, muitas vezes, senão a maioria delas se inicia ou se dá no campo do desejo. O ato erótico desregrado - 
entre pessoas do mesmo sexo, de diferentes idades, em locais públicos - é um instrumento de enfrentamento às normas sociais e políticas pois, nesse discurso, está associado a rebeldia (versus conformismo), ao profano (versus sagrado) e a obscenidade/voluptuosidade (versus puritanismo). É uma operação poética que visa euforizar os valores demarcados como disfóricos pela sociedade que preza pela "moral e pelos bons costumes"

\subsubsection{A isotopia}

Segundo Rastier, em seu estudo "A sistemática das isotopias" (GREIMAS, 1976: 96-125), é possível estabelecer três tipos básicos de tematização: a prática, a mítica e a metalinguística. Na tematização prática, o sentido do percurso figurativo é fruto de leituras denotativas, por estar ancorado na cena enunciativa formada da enunciação e realizada no enunciado. Na tematização mítica, o sentido do percurso figurativo ganha sentido a partir de uma leitura conotativa, mais abstrata, ligada à leitura denotativa construída na tematização prática. Já na tematização metalinguística o significado do percurso figurativo remete a si mesmo.

No poema de Piva, pode-se pensar que o efeito de sentido de objetividade gerado na sintaxe discursiva nos dois primeiros versos instala, na semântica discursiva, uma tematização prática, na qual o embate erótico amoroso pode ser entendido como o ato sexual em si, figurativizado pela "cama" e pelos "lençóis desarrumados". A partir do terceiro verso, a instauração da debreagem enunciativa, com a categoria de pessoa "eu" discursivizada, permite a subjetivização da interpretação do embate erótico amoroso, o que, no nível semântico, abre espaço para a tematização mítica, na qual o embate erótico amoroso é metaforizado com o "nascer para a madrugada". 
Algumas definições do verbo "nascer" merecem destaque":

1- sair do ovo

2- começar a manifestar-se

3- derivar-se, provir

4- formar-se, constituir-se

Em todas essas definições está implícita uma transformação, uma passagem de um estado a outro, através de uma ação do sujeito sobre ele mesmo. Até mesmo a definição mais corrente do verbo - sair do ventre materno - indica uma ação do sujeito sobre si; não há a ideia de um destinador que dota o sujeito de competências para a realização da performance, nem de adjuvantes para fazê-lo, pois o sujeito é seu próprio destinador, reunindo, em si mesmo, as modalidades e competências para a realização do seu percurso, e o realiza de fato.

A metáfora "nascer para a madrugada" serve de base para a interpretação não só deste poema, mas de todo o discurso da poesia de Roberto Piva no volume Mala na mão \& asas pretas. Nos poemas desse volume, a noite não é apenas uma paisagem, é uma força geradora da vida em todo o seu vigor. O poema inicial de Abra os Olhos \& diga Ah! afirma: "No útero da maça/ tudo começa/ a anoitecer/ cheio de energia". A noite, nesse sentido, é o gatilho que aciona a força vital de cada ser, é o agente transformador dos sujeitos. Não se trata apenas de viver a vida noturna, mas sim de deixar que a noite, quase como uma entidade, tome conta de todas as instância de atuação da vida. Pode-se dizer que é a construção de um ethos noturno.

\footnotetext{
${ }^{9}$ Dicionário Priberam de Língua Portuguesa
} 
Com exceção da passagem da segunda para a terceira linha e da oitava para a nova linha, todos os outros versos estão ligados uns aos outros por enjambements, o que dificulta a interpretação. O percurso linear do poema é o seguinte: a cama é o espaço onde o sujeito "eu" começa a nascer para a madrugada; nas vertigens da madrugada o "tu" amado se enrosca no coração paranóico de veludo verde do "eu"; as delícias dos continentes alaranjados dormem no rosto de pérolas turvas do "tu"; os tambores do amor seguem rumo às tempestades planetárias \& suas cachoeiras tristes e pesadas como lágrimas; o "eu" afirma que gosta de gostar e, por fim, a tv da alma amanhece bêbada e tenta dizer alguma coisa.

Nesse percurso as duas tematizações, prática e mítica, se confundem e se misturam. A tematização prática cria a cena do ato erótico amoroso, com o "eu" e o "tu" no "ali", que é a cama. Essa leitura é apoiada pelos verbos enroscar-se, dormir, gostar e amanhecer. A tematização mítica, apoiada na leitura prática, é o que permite que as imagens delirantes do poema possam ser organizadas e interpretadas.

As figuras do poema são feitas pela junção de elementos díspares entre si, o que gera um efeito de surrealidade. Esse delírio figurativo é muito presente em toda a obra de Roberto Piva e, muitas vezes, uma interpretação razoavelmente lógica parece impossível ou, ao menos, improvável. Vale fazer uma pequena consideração sobre o surrealismo em sua obra, pois, embora a influência surrealista seja forte, principalmente no que diz respeito a figuratividade, há que se ponderar sobre a afirmação freqüente de que Piva é um "poeta surrealista". Até mesmo seus manifestos de Os que viram a carcaça, de Um estrangeiro na Legião, ditos surrealistas, diferem dos de Breton em muitos sentidos, principalmente na supressão do caráter argumentativo, marcante no autor francês. Além disso, o imaginário da poesia piviana é essencialmente brasileiro; o amor, ainda que não demarcado em todos os 
poemas, é essencialmente homoerótico e a influência política é "anarco-monarquista", como declarava o poeta, e não marxista.

\subsubsection{O delírio figurativo}

O poema se constrói majoritariamente pela união de figuras muito diferentes entre si. Esse encadeamento de figuras é denominado percurso figurativo. Nesse poema, o percurso criado constrói sintagmas cuja referência ao mundo natural é tão improvável que cria-se um efeito de delírio figurativo.

Os versos nos quais o delírio figurativo é mais presente são os versos 5 e 6 que constituem, juntos, o centro do poema, com 4 versos acima do primeiro, e 4 abaixo do segundo:

\begin{tabular}{|c|c|}
\hline (A EPOPÉIA DO AMOR COMEÇA NA CAMA COM OS LENÇÓIS & 1 \\
\hline DESARRUMADOS FEITO UM CAMPO DE BATALHA) & 2 \\
\hline é ali que eu começo a nascer para a madrugada \& suas & 3 \\
\hline vertigens onde você meu amor se enrosca em & 4 \\
\hline meu coração paranóico de veludo verde \& as delícias de continentes & 5 \\
\hline alaranjados dormem em seu rosto de pérolas turvas oh tambores do amor & 6 \\
\hline sem parar rumo às tempestades PLANETÁRIAS \& suas & 7 \\
\hline cachoeiras tristes \& pesadas como lágrimas & 8 \\
\hline gosto de gostar \& a tv da alma amanhece bêbada \& tenta & 9 \\
\hline dizer alguma coisa & 10 \\
\hline
\end{tabular}


É interessante apontar também que esses versos centrais são os mais longos, sendo que cada um possui 22 sílabas poéticas, enquanto os outros apresentam o número máximo de 16. É evidente que essa metrificação cria um ritmo mais acelerado do que o dos outros versos, e essa aceleração no plano da expressão, gerada por fonemas associados de forma direta e sem interrupções, está associada, no plano do conteúdo, a esse efeito de delírio figurativo, com a criação de seqüências de imagens aparentemente desconexas entre si e de difícil interpretação lógica.

Nesses dois versos centrais, além da metáfora, que é recorrente em todo o poema, nota-se a presença notável da sinestesia, entendida no seu sentido retórico, como a combinação de percepções de natureza sensorial distinta. "O coração paranóico de veludo verde" mistura o "coração", uma figura de referente físico, com o estado mental de "paranóia", ou seja, uma paixão que gera perturbações psíquicas, o "veludo", um tecido fortemente marcado pela textura ao tato, portanto referente ao háptico, e o "verde", uma grandeza óptica. O "veludo verde" pode ser entendido como um tecido da cor verde, o que, por sua vez, remete as figuras da "cama" e dos "lençóis desarrumados", e o "coração paranóico" é a metaforização de um estado mental expandido ao espaço do corpo físico, sendo que o coração, nesse sentido, é a metonímia da parte do tórax do "eu", envolto em um tecido de veludo verde.

O verso seguinte faz operações de natureza semelhante. Enquanto as imagens fazem associações que podem, em sentido denotativo, evocar sentidos como o paladar, o tato ou a visão, a isotopia do poema nos leva a criar uma cena, na qual o "eu" observa o ser amado dormindo no cama, e as "delícias dos continentes alaranjados" e o "rosto de pérolas turvas" representam, metaforicamente, um rosto cuja textura remete a uma pérola, portanto lisa e bela, mas de coloração escurecida. Nesse sentido, se pensarmos que o laranja do continente 
é um traço referente ao sol, as "delícias dos continentes alaranjados" que dormem no rosto do amado são uma espécie de traço físico-biológico refletido na pele.

O final do verso 6 e os versos 7 e 8 figurativizam os temas da turbulência e da tristeza, referentes a configuração discursiva amor. Os tambores do amor se movem em direção a grandes turbulências, o que acaba por gerar a tristeza. São as atribulações causadas pelo ato de amar. Os tambores caracterizam ruídos ritmados que, no contexto do poema, podem ser entendidos como pequenos desentendimentos cotidianos no campo do amor, porém o destino desse "barulho" é se repetir constantemente até tomar grandes proporções, gerando tempestades PLANETÁRIAS - com esse segundo elemento sendo marcado de forma mais intensa pelo uso das letras em maiúscula - que, por sua vez, resultam em um estado de tristeza, pesar e lágrimas.

O que poderia ser considerado como negativo, no entanto, não o é, como se pode perceber no começo do verso 9. "Gosto de gostar" funciona como uma sanção positiva dos percursos percorridos pelo amor, tanto o percurso do prazer e da afeição, quanto o da turbulência e da tristeza. Para o poema, todos os temas e figuras derivados do amor são euforizados, pois todos estão relacionados a valores de liberdade.

\subsubsection{Considerações finais sobre o poema}

O poema apresentado é muito representativo no que diz respeito à poesia de Roberto Piva e ao discurso presente no coletânea Mala na mão \& asas pretas. Características como a disposição irregular dos versos, o efeito de alucinação e o delírio figurativo, o valor de liberdade como fundador de temas e figuras, a centralidade do sexo como forma de enfrentamento ou transformação, a preferência pela noite e o apelo aos sentidos são traços distintivos da obra de Roberto Piva, que acreditava que a poesia e a literatura eram campos 
através dos quais era possível combater os cercos impostos à toda forma de vida. Para resumir melhor essas ideias, as palavras de Álcir Pécora, organizador da coletânea:

... este volume pode ser lido como um grande poema de amor encarregado de uma proeza política: atravessar o inferno de pijamas, família, TV, vida doméstica, trabalho odioso e subalterno, autoridades cômicas, direita e esquerdas fascistas etc. - todo o domínio da 'ordem Kareta', na qual se é cego de puro medo. Uma proeza imensa e arriscada, que no limite de sua destinação se amplifica como passagem inaugural do nada ao ser, isto é, como cosmogonia.

\subsection{Dever $X$ querer: análise de um poema}

O poema abaixo é o número XVI do livro 20 poemas com brócoli, publicado originalmente em 1981, editado por Massao Ohno com associação de Roswitha Kempf, e é o terceiro livro presente em Mala na mão \& asas pretas, volume 2 das obras reunidas.

abandonar tudo. conhecer praias. amores novos.

poesia em cascatas floridas com aranhas azuladas nas samambaias.

todo trabalhador é escravo. toda autoridade

é cômica. fazer da anarquia um

método \& modo de vida. estradas.

bocas perfumadas. cervejas tomadas

nos acampamentos. Sonhar Alto.

O poema XVI é composto por 11 frases curtas, o que cria um ritmo de leitura pausado pelo uso dos pontos finais, não há uso de letras maiúsculas e as frases não estão dispostas uma abaixo da outra, criando o aspecto de lista, mas há enjambements entre várias linhas do poema, com exceção apenas das linhas 1 e 6 . Além disso, a disposição dos versos 
na página e entre si não segue uma linearidade vertical, ou seja, o começo dos versos não se dá de forma alinhada em relação a página. O uso desses recursos - frases curtas separadas por pontos finais, ausência de letras maiúsculas no início das frases e enjambements e versos desalinhados - são recorrentes em todo o livro 20 poemas com brócolis.

A temática do poema evoca fortemente alguns temas da literatura da beat generation americana, como a recusa ao trabalho formal, conhecer lugares e amores novos, viajar e viver desregradamente. Basta lembrar do livro On the road, de Jack Kerouac, considerado por muitos críticos como o marco inicial da geração beat, e é inspirado na vida do próprio Kerouac, que narra a história de dois jovens, Sal Paradise e Dean Moriarty (que seriam Jack Kerouac e Neil Cassidy), que atravessaram os Estados Unidos de carro, numa viagem repleta de paisagens, garotas, bebida, drogas, diversão e amigos.

Os temas da poesia beat, citados acima, estão diretamente ligados a temática mais importante dessa literatura norte-americana e também da poesia de Roberto Piva, o tema da liberdade, que é também o objeto de valor final de qualquer percurso narrativo realizado pela poesia desses autores, assim como seu valor fundamental. Nesse sentido, tudo que aprisiona o sujeito a uma posição estática ou de inércia é considerado negativo. Pode-se dizer que há uma primazia do /querer/ sobre o /dever/, pois o significado deste último está sempre ligado a obrigações, como se pode ver na definição dicionarizada do termo ${ }^{10}$ :

dever (latim debeo, -ere)

1. Estar obrigado a.

2. Ser necessário.

3. Ter de suceder.

4. Ter dívidas.

\footnotetext{
${ }^{10}$ Dicionário Priberam de Língua Portuguesa
} 
5. Ser provável que.

6. Ter a dívida de.

7. Estar reconhecido (a alguém) por.

s. $m$.

8. Ato que tem de se executar em virtude de ordem, preceito ou conveniência.

9. Obrigação.

A maioria dos semas expresso na definição do dever está relacionada a ideia de obrigação, de ter de fazer algo, é uma imposição com a qual o sujeito tem que se comprometer, independente de querer ou não, ou seja, o dever é algo que restringe a liberdade. Para o poeta Roberto Piva, e também dos poetas norte-americanos, o /dever/ é um valor imposto em todos os níveis da sociedade, como o político, o religioso, o amoroso e o social, o que acaba por cercear a manifestação da individualidade do sujeito, que tem de ajustar-se a um leque de escolhas limitadas, ou seja, seguir alguns valores e rejeitar outros. A poesia de Roberto Piva dá preferência ao querer.

querer (latim quaero, -ere, procurar, buscar, perguntar, informar-se, procurar obter, pedir)

v. $t r$.

1. Ter a vontade ou a intenção de.

2. Anuir ao desejo de outrem.

3. Ordenar, exigir.

4. Procurar.

5. Poder (falando de coisas).

6. Requerer, ter necessidade de.

7. Fazer o possível para, dar motivos para.

8. Permitir, tolerar (principalmente quando acompanhado de negação). 
9. Admitir, supor.

v. intr.

10. Exprimir terminantemente a vontade.

11. Amar, estimar.

v. pron.

12. Desejar estar, desejar ver-se.

13. Amar-se.

s. $m$.

14. Desejo, vontade.

A busca da liberdade está ligada ao /querer/, no sentido de que ele representa um impulso individual do sujeito, antes de passar pelo filtro da obrigação social, representado por uma série de deveres. O /querer/ é o que impulsiona o sujeito, é o elemento necessário para a liberdade, pois é o que tira o sujeito da inércia e o que o mantém em movimento. Nesse poema, a liberdade está na desordem, na anarquia, no espaço aberto, na infinitude de possibilidades, no prazer, em viver sem deveres e em função do querer. As "praias", os "amores novos", a "poesia em cascatas floridas", as "estradas", as "bocas perfumadas" e as "cervejas tomadas nos acampamentos" são a figurativização do tema da liberdade. As "praias", as "cascatas floridas com aranhas azuladas nas samambaias", as "estradas" e os “acampamentos" representam o espaço aberto, ou seja, a possibilidade de movimento, o não aprisionamento em um lugar fixo, os "amores novos", as "bocas perfumadas" e as “cervejas" representam o prazer.

É possível pensar que o poema se divide entre as frases que expressam algo negativo para o sujeito, pois representam valores rejeitados por ele, e frases que expressam algo positivo, pois revela valores com os quais ele quer entrar em conjunção. As frases tidas como negativas são 
"abandonar tudo", "todo trabalhador é escravo" e "toda autoridade é cômica", pois tematizam a opressão. O sujeito quer, portanto, fugir de tudo, afastar-se da vida que leva, pautada na ordem e enraizada em um local fixo, pois considera que o trabalho é uma escravidão e, de fato, qualquer forma de trabalho é pautada em um /dever/ e é o que o sujeito procura evitar. A "autoridade" é o poder fazer fazer, em outras palavras, é o que inflige o /dever/ e, portanto, cômica, motivo de riso, pois não é um poder legítimo para o sujeito do poema. O verso que segue também está, de certa forma, ligado ao /dever/, "fazer da anarquia um método \& modo de vida" é a opção que se faz necessária para que a liberdade se torne possível. Nesse sentido, o discurso e o modo de dizer formam uma contradição, pois para que o /querer/ seja alcançado, há um /dever/ a ser adotado, que deve constituir um método e um modo de vida o que, por sua vez, pressupõe uma ordem, um processo organizado a ser feito para atingir um fim, enquanto a própria semântica de "anarquia" sugere a desordem. Estabelece-se, então, uma oposição entre o querer e o dever entre as frases que compõe o poema.

\begin{tabular}{|c|c|}
\hline \multicolumn{1}{|c|}{ /dever/ } & /querer/ \\
\hline abandonar tudo & conhecer praias \\
\hline todo trabalhador é escravo & amores novos \\
\hline toda autoridade é cômica & poesia em cascatas floridas com aranhas \\
& azuladas nas samambaias \\
\hline vida & estradas \\
\hline & cervejas tomadas nos acampamentos \\
\hline
\end{tabular}


O plano do conteúdo, muitas vezes, encontra na poesia uma relação mais direta com o plano da expressão, o que quer dizer que os significados relacionam-se diretamente com os significantes. Em outras palavras, uma forma de expressão, no caso da poesia, sons, é relacionada com uma forma de conteúdo, ou seja, com categorias semânticas. São os chamados sistemas semi-simbólicos.

\subsubsection{O semi-simbolismo no poema XVI}

A princípio, essa sistematização chama a atenção para um fato interessante, as frases ligadas ao /dever/ estão todas no singular, enquanto as ligadas ao /querer/ estão todas no plural. Inicialmente, pode-se associar a flexão de número singular a uma padronização, uma uniformidade, disforizada, enquanto o plural seria a multiplicidade, euforizada. No entanto, através de uma análise lingüística mais apurada, é possível chegar a conclusões mais interessantes.

Sonoramente, logo a princípio, é possível perceber uma diferença entre as frases da primeira coluna e as frases da segunda. A coluna do /dever/ parece ser composta por sons com paradas mais bruscas, enquanto a do /querer/ parece ser composta por sons mais fluidos. Foneticamente, isso está relacionado ao modo como a corrente de ar sai do aparelho fonador, o que é chamado de modo de articulação. Na primeira coluna há o predomínio de consoantes oclusivas, e na segunda coluna, de consoantes fricativas.

As consoantes oclusivas são dividas entre surdas - [p], [t], [k] e sonoras - [b], [d], [g]. Segundo o livro Introdução à Lingüística II, oclusivo é "o som produzido pelo fechamento completo dos articuladores na cavidade oral de modo que o ar não possa escapar. O véu palatino também se encontra levantado, de modo que o ar não pode escapar pela cavidade nasal. Quando os articuladores se abrem, a corrente de ar sai como 
numa explosão (por isso, esses sons também são conhecidos como plosivos). São exemplos de sons oclusivos os sons consonantais em cata, gaba” (FIORIN, 2004: 21). Isso quer dizer que esse grupo de sons é produzido inicialmente pelo fechamento do canal bucal seguido de uma abertura brusca. São sons oclusivos as ocorrências das consoantes t, b e g e som de [k], que ortograficamente aparece como $c$ (de escravo e cômica) e qu (de anarquia). Há o evidente predomínio dos sons oclusivos na primeira coluna.

A coluna do /querer/ é inteiramente por frases com término em plural. De fato, a presença maciça do plural é o que mais chama atenção na segunda coluna. No português, o plural é composto pela consoante - s final que, de acordo com o modo de articulação, é fricativa. Novamente, de acordo com o livro Introdução a Lingüística II, fricativos "são os sons produzido por uma aproximação dos articuladores, estreitando o trato vocal de modo que o ar saia produzindo fricção. Exemplos de sons fricativos são os sons consonantais de fava, sã e chave" (FIORIN, 2004: 21). As consoantes fricativas, ao contrário das oclusivas, não são produzidas por uma abertura brusca, mas por uma saída contínua do ar, fazendo uma fricção entre os articuladores. São exemplos de sons construtivos presentes no poema $[\mathrm{f}],[\mathrm{v}],[\mathrm{s}],[\mathrm{z}]$, como todos os $-\mathrm{s}$ finais, que realizam o plural, e as consoantes em destaque a seguir: conhecer, novos, poesia, cascatas, floridas, azuladas, samambaias, estradas, perfumadas e cervejas.

A partir do que foi dito acima, pode-se pensar que, no plano da expressão, portanto, a predominância das consoantes oclusivas na primeira coluna, a do /dever/, cria um efeito de descontinuidade, enquanto a predominância de consoantes fricativas na segunda coluna, a do /querer/, cria um efeito de continuidade. No plano do conteúdo, o dever também representa a descontinuidade, no sentido de que é o que obstrui a vida do sujeito, a 
faz permanecer estática, enquanto o querer é a continuidade, que é o impulso necessário para o andamento da vida.

Vale aqui lembrar o trabalho "Semióthique plastique et communication publicitaire" de Jean-Marie Floch, no livro Petytes Mythologie de l'oeil et de l'esprit (FLOCH, 1985: 139-186), no qual o autor analisa o comercial de cigarros da marca News, que é composto por uma foto montagem e os dizeres "take a break in the rush". Segundo o autor, a continuidade caracteriza o processo temporal que é o "rush", a correria do dia a dia, enquanto a descontinuidade caracteriza o "break", a pausa no meio dessa agitação. Foneticamente, "take a break" é composto, majoritariamente, por consoantes oclusivas, enquanto em "in the rush" predominam as consoantes constritivas vibrantes (r) e constritivas fricativas, o (sh). O plano de expressão da primeira unidade (take a break) é marcado pela descontinuidade, e na segunda unidade (in the rush) ocorre a continuidade. Essa oposição do plano da expressão encontra sua correspondência, no plano do conteúdo, às categorias semânticas, respectivamente, de identidade e alteridade. Deixando de lado a análise da foto montagem, considerando apenas a análise da parte lingüística do anúncio, o autor nos dá a seguinte esquematização (FLOCH, 1985: 163):

$\begin{array}{cccc}\text { Plano da expressão: } & \text { consoantes oclusivas } & \text { vs } & \text { consoantes constritivas } \\ & \text { descontinuidade } & \text { vs } & \text { continuidade }\end{array}$

Plano do conteúdo: iniciativa de uma pausa vs participação da correria /identidade/ Vs /alteridade/ 
Para simplificar o entendimento, acrescenta-se abaixo ao esquema de Floch a valorização narrativa referente ao anúncio, na qual a euforia é o que é desejado e buscado e a disforia é o que é rejeitado:

$$
\text { euforia vs disforia }
$$

O anúncio em questão realiza a valorização do /identidade/, da pausa, no plano do conteúdo e, portanto, da descontinuidade e das consoantes oclusivas, no plano da expressão. Há uma busca pela pausa, da parada, na agitação e correria do cotidiano, que é o que o cigarro representa. No entanto, essa análise é aplicada para este anúncio em particular, pois cada discurso constrói uma rede de relações específica, na qual um elemento é valorizado em relação a outro, de forma arbitrária. Em outra propaganda, por exemplo, podem ser estabelecidas relações que valorizem a alteridade e a continuidade.

O poema de Roberto Piva traça uma rede de relações semelhante:

Plano da expressão: consoantes oclusivas vs consoantes fricativas descontinuidade vs continuidade

Plano do conteúdo: vida regida pelo dever vs vida regida pelo querer

$\begin{array}{lll}\text { /opressão/ } & \text { vs } & \text { /liberdade/ } \\ & & \\ \text { disforia } & \text { vs } & \text { euforia }\end{array}$

Como se pode observar, no plano de expressão são construídas relações muito semelhantes, as consoantes oclusivas são descontínuas e as consoantes fricativas são 
contínuas. Entretanto, ao relacionar o plano da expressão ao plano do conteúdo, algumas diferenças são percebidas.

As categorias semânticas que estão em jogo no poema de Roberto Piva são a /opressão/ - vida regida pelo dever e a /liberdade/ - vida regida pelo querer. Piva constrói uma rede de relações na qual a continuidade, do plano da expressão, está relacionada à /liberdade/, no plano do conteúdo (euforia) e a descontinuidade liga-se à /opressão/ (disforia). Isso mostra que as relações traçadas variam de discurso para discurso e representam diferentes visões de mundo. Para o sujeito do poema, uma obstrução não é algo positivo, mas sim algo que o impede de manter-se em movimento. A pausa buscada e desejada pelo sujeito que adere ao discurso do anunciante do cigarro News não é valorizada pelo sujeito do poema do autor brasileiro.

É possível pensar nas categorias semânticas de base no poema como /alteridade/ e /identidade/ também. Dessa forma, a vida regida pelo dever seria uma afirmação da /alteridade/, isto é, de obrigações sociais, e a vida regida pelo querer seria uma afirmação da /identidade/. Contudo, os poemas de Roberto Piva, tem um caráter social e político, de colocação do sujeito perante a sociedade, que demonstram um embate impetuoso e um enfrentamento pela escolha do modo de vida em oposição a outro imposto socialmente que é melhor demonstrado por /opressão/ e /liberdade/ do que por /identidade/ e /alteridade/.

A última frase do poema, "Sonhar Alto" compõe uma parte particular do poema, pois é o único momento no qual há a presença de letras maiúsculas, o que, num poema composto por 11 frases, todas com as palavras iniciadas por letras minúsculas, é bem significativo. O verbo "sonhar" remete a devaneios, à irrealidade e à fantasia; "alto" remete a um movimento para cima, a algo elevado e grande. Esse trecho do poema pode ser 
entendido de duas maneiras, como algo que o sujeito quer, juntamente com os demais percursos descritos pelas frases que refletem o querer; nesse caso, assim como o sujeito quer conhecer praias e amores novos, também quer sonhar alto. Por outro lado, pode sugerir a leitura de todo o poema como um devaneio, ou seja, tudo o que o sujeito deseja está no plano dos sonhos, da ilusão. As duas possibilidades, porém, não são tão distantes, e possuem em comum o fato de que, em qualquer dos casos, esses percursos do querer não fazem parte da vida do poeta, é o que ele almeja, e para alcançar isso, ele precisaria "abandonar tudo".

\subsection{O jet set do amor maldito}

eu sou o jet set do amor maldito

DENTRO DA NOITE \& SUAS CÓLICAS ILUMINADAS

os papagaios da morte com Aristóteles na proa do trovão

DISPOSIÇÃO DE IR À DERIVA NOS DADOS DO AMOR

espinafre pela manhã \& queijo em pasta

almas-esportivas com flores entre os dentes

minha laranja se abrindo como uma porta

TUA VOZ É ETERNA eu vejo a mão cinzenta rasgar

a parede do mundo

ESTAMOS DEFINITIVAMENTE NA VIDA

Nesse poema, o sujeito afirma ser o "jet set do amor maldito", sendo que jet set, nesse caso, não tem o sentido tradicional de pessoa que leva um estilo de vida rico, viajando freqüentemente em aviões particulares, os jatos. Jet set, no contexto do poema e do discurso da obra piviana, pode ser entendido como o representante de um estilo, aquele 
que ostenta uma maneira de vida particular, no caso, o "amor maldito", que por sua vez, também deve ser entendido dentro desse discurso. O "amor maldito" é o sentimento de afeição ou atração sem conotações religiosas ou de pureza, não é um amor idealizado ou cristão, ele é "maldito" no sentido de ser mal visto e incômodo, o que é uma referência, porém não tão explícita, ao amor homerótico, que domina grande parte do discurso do livro, sempre se opondo aos valores amorosos valorizados pela sociedade.

Alguns semas do poema remetem a isotopia de viagem, como "jet set", "proa" e "ir à deriva". Como dito anteriormente, jet set é o nome dado a pessoa com alto poder aquisitivo que viaja frequentemente em jatos particulares, proa é a parte dianteira de um barco ou navio e ir à deriva é o movimento ou percurso descontrolado de um veículo marinho, por alguma falha mecânica ou efeito de uma corrente marítima ou de vento, que faz com que o operador não consiga que seus comandos sejam seguidos. Em geral, os significados mais comuns de viagem é o ato de transportar-se de um ponto a outro distante, navegação, travessia e percurso efetuado ${ }^{11}$. Esses semas remetem a passagem de um estado a outro no tempo e no espaço, o que é entendido como a mudança que transcorre com o sujeito do começo ao final do poema.

Mais uma vez, a noite aparece como espaço privilegiado para transformação e para a agitação, como confirmado a seguir pelas "cólicas", que evocam um movimento de contorção por dor abdominal. A semântica da palavra "cólica", que contém os semas de "dor" e "contorção abdominal” iniciam uma isotopia que servirá para a interpretação do poema. Como foi dito antes, a metáfora "nascer para a madrugada" serve como base para a interpretação do discurso do livro. Esse poema encena um nascimento, mas não no sentido de parto, mas sim como uma renovação, de vinda ao mundo com uma nova visão.

11 Dicionário Priberam de Língua Portuguesa 
Retomando “A sistemática das isotopias", de Rastier (GREIMAS, 1976: 96-125), encontramos, nesse poema, as tematizações prática e mítica. As "cólicas", a "laranja se abrindo como uma porta" e a "mão cinzenta" que rasga a parede do mundo são figuras que permitem uma leitura pela tematização prática, que ancora uma leitura mais abstrata, dita mítica, através da qual é possível criar a cena de um nascimento, de sair de um espaço restrito para um espaço aberto. As cólicas seriam então as contrações do parto, a laranja se abrindo como uma porta é a dilatação do cérvix e, por fim, a mão cinzenta rasgando a parede do mundo é a expulsão fetal. É um nascimento, porém não no sentido literal, e o resultado final é o princípio de uma nova forma de estar no mundo, como dito no término do poema "ESTAMOS DEFINITIVAMENTE NA VIDA". Essa leitura é ancorada também no discurso do poema anterior a esse no livro, que termina com "No útero da maça/ tudo começa/ a anoitecer/ cheio de energia".

\subsection{Homoerotismo}

... ce qui t'est demandé est la

pureté de l'enfer - ou, si tu

aimes mieux, de l'enfant...

Georges Bataille, L'Alleluiah (abertura de 20 poemas com brócoli)

A poesia de Roberto Piva, no que concerne a tematização do amor e do desejo, não esconde seu caráter homoerótico, em todos os livros, porém nesse segundo volume, isso aparece de forma bem evidente e marcada. Além da narração poética do ato sexual entre homens, mais explícito nos poemas de Coxas, sex fiction \& delírios, logo no início de Abra os olhos \& diga Ah! já há marcas fortes dessa temática. Além disso, há de se dizer que o 
foco do desejo homoerótico são os garotos, essa energia sexual volta-se para os efebos que povoam o imaginário e a vida do sujeito poético, adquirindo muitas vezes um caráter de divindades, de fontes de energia que alimentam esse sujeito.

O amor e o desejo são direcionados a figuras masculinas, e frequentemente demarcados como jovens ou adolescentes, seja de forma explícita ou depreendidos linguisticamente através do uso de pronomes ou artigos do gênero masculino. O primeiro poema fala dos "olhos do meu amante" (grifo nosso), enquanto outros falam, por exemplo, de "teu gemido à sombra / de cuequinhas em flor", "garoto pornógrafo", “desejo trovejante do coração / partido pelo amor / em sua disparada pelo rosto de um / adolescente". A temática do amor de efebo usa referências diretas da mitologia grega e romana, como o mito de Ganimedes e de Antinous, ambos intitulando poemas e também servindo como temas ou figuras, como no poema 9. Norte/Sul: "o garoto sofreu o ataque da ave de rapina chamada Zeus \& / seus testículos hipnotizaram a luz do sol vedando a / adoração da luz para os patriotas do porno-samba \& / suas matracas tatuadas” (Coxas, pág. 82-83).

Ganimedes, de acordo com a mitologia grega, era um príncipe de Troia, que cuidava do rebanho do seu pai, quando foi avistado por Zeus, que se apaixonou imediatamente por ele, seu encantamento e desejo foram tão grandes que o deus transformou-se em águia e o raptou, possuindo-o durante o vôo. Zeus levou o jovem ao Olimpo e, apesar da fúria e do ciúme de sua esposa Hera, que costumava perseguir e fazer sofrer as amantes do marido, Ganimedes recebe o posto de servir o néctar da imortalidade aos deuses, substituindo a deusa Hebe, filha de Zeus e Hera. Após servir aos deuses, o jovem Ganimedes derramava os restos do néctar sobre a terra, para os homens.

Antinous, ou Antínoo, por sua vez, era um jovem de grande beleza que viveu com o Imperador Adriano Augusto, trinta e quatro anos mais velho do que ele. Embora haja 
discrepâncias em torno das versões sobre o relacionamento dos dois, a maioria acredita que tratava-se de uma relação erótico-amorosa. Após a morte por afogamento do jovem, o Imperador decretou a deificação de Antinous, aproximadamente no ano 130 d.C, e ordenou a construção de templos em honra do novo deus e de uma cidade próximo ao local de sua morte. A cidade de Antinóopolis do antigo Egito ficava na região onde hoje localiza-se Sheikh Ibada.

Aparecem, no livro Abra os olhos \& diga Ah!, em sequência, poemas com o título “Ganimedes 76”, “Afetando profundamente o emocional (Antínoo, ragazzo di marbro)” e “Antinous (movimento das árvores)". No poema "Bar Cazzo d'oro” (pág. 76-77) aparece “Ganimedes Antinous / mais velozes que o sal do prazer crescendo na bolha do / orgasmo mais fundo", além de outro poema com o título “Antínoo \& Adriano" (pág. 84-85), que apresenta como epígrafe o seguinte trecho de "Antinous", poema escrito em inglês por Fernando Pessoa, "the rain outside was cold in / Hadrian's soul".

A alusão a Ganimedes e a Antinuos remonta ao tempo da Grécia e Roma antigas, a um outro cenário cultural no qual a forma de conceber e interpretar o mundo era diferente, o que tem por resultado um discurso que abarca conceitos, ideias, temas, figuras e valores diversos ao do tempo atual (considerando o tempo atual o momento de escrita do poema). O livro Antiguidade Clássica, uma brevíssima introdução, diz que "todas as formas de excentricidades, desde o sufrágio universal e a democracia até o vegetarianismo, do panteísmo e do amor livre à eugenia e ao genocídio, encontraram precedentes e autoridades nos clássicos" (BEARD \& HENDERSON, 1998: 86). O comportamento homossexual na Grécia antiga não sofria represálias ou se apresentava como um interdito a determinadas ideologias, e o contato sexual entre indivíduos do mesmo gênero era algo corrente na Grécia, porém as relações entre homens mais velhos e homens mais jovens, a princípio, não 
tinha o viés unicamente sexual, pois envolvia a transmissão da sabedoria dos mais velhos aos mais jovens, como maneira de formar os cidadãos; era, portanto, um comportamento legítimo e até mesmo desejável. Segundo Beard \& Henderson “a discussão de Platão sobre a natureza do amor e do desejo no Banquete foi usada para justificar certas formas de homossexualidade masculina: Platão não apenas admitia relações sexuais entre homens e meninos; na verdade, como outros aristocratas contemporâneos, considerava-as a forma mais nobre e elevada de desejo sexual" (idem, p. 86), o que pode ser depreendido do trecho abaixo do próprio O Banquete:

E todos os que são corte de um macho perseguem o macho, e enquanto são crianças, como cortículos do macho, gostam dos homens e se comprazem em deitar-se com os homens e a eles se enlaçar, e são estes os melhores meninos e adolescentes, os de natural mais corajoso. Dizem alguns, é verdade, que eles são despudorados, mas estão mentindo; pois não é por despudor que fazem isso, mas por audácia, coragem e masculinidade, porque acolhem o que lhes é semelhante. (...) E quando se tornam homens, são os jovens que eles amam, e a casamentos e procriação naturalmente eles não lhe dão atenção, embora por lei a isso sejam forçados, mas se contentam em passar a vida um com o outro, solteiros. (PLATÃO. O Banquete, 191 -192)

A preferência do poeta pelo período da adolescência, do limite entre a infância e a vida adulta, explica-se não só por ser o período de maior beleza e virilidade, mas também por ser uma fase em que a liberdade é maior, pois ainda há um caminho a ser escolhido, percursos diversos a serem trilhados, não há ainda um grande compromisso com as imposições da vida adulta, além de estes serem indivíduos em formação, buscando e 
aceitando mais facilmente ideias novas e atividades diferentes para serem feitas. A adolescência é, por excelência, um período de rebeldia, de confrontar-se com as figuras, obrigações e os valores da sociedade tradicional, travando, muitas vezes, um combate com toda essa "ordem Kareta". É, também, por excelência, o período do desenvolvimento da sexualidade, da descoberta do prazer, da ebulição hormonal que resulta em voluptuosidade e insaciedade dos desejos. Em essência, essa espécie de fixação com a figura do adolescente é um desejo não só de cercar-se da companhia de jovens, mas também de querer ser como eles. A figura do adolescente está ligada também ao mundo noturno, pois a noite é povoada por adolescente, em busca de diversão, amor e prazer.

As relações de pederastia já estavam presentes no livro Um estrangeiro na legião, no entanto, em Mala na mão \& asas pretas, a força do tema do sexo eleva essas relações de pederastia a um nível mais intenso. Em outras palavras, o desejo direcionado aos jovens era uma temática menos constante e um pouco mais moderado. Alguns trechos ajudarão a esclarecer essas afirmações:

1.

“(..)

há uma epopéia nas roupas penduradas contra

o céu cinza

e os luminosos me fitam do espaço alucinado

quantos lindos garotos eu não vi sob esta luz?" ("Meteoro”, Um estrangeiro na legião, p. 71)

2.

“Um dos 'robots' correra para junto da

criança \& pegara nela ao colo, acariciando-a com uma gentileza que não parecia ser possível num 'robot' 
daquelas dimensões"

Isaac Asimov (epígrafe de "O robot pederasta", Um estrangeiro na legião, p. 82)

3.

Piazza VI

Algumas vezes

as bombas de sorvete

caindo há 15 anos

durante a tempestade

Sem ler

Freud ou Villon

os garotos

rompem barreiras

então em qualquer

terreno baldio

iluminam

vestem-se

no furação do amor humano

onde

um cometa se desdobra

TESTE DI RAGAZZI CHE RIDONO

nos céus de whisky

em cada canto da BOCA

cósmica ("Piazza VI", Um estrangeiro na

legião, p. 93)

4.

“(...)

Meu circuito de trincheiras pela mesma razão de ninho

De águia 
tempo em que os 12 andares do sexo correm persianas

De galalite

relâmpagos do mesmo líquen magnético de tua boca

De quinze anos

quando não vais à escola para assistires Flash Gordon

\& ler Otto Rank nas esquinas

o mundo continua sendo um breve colapso logo que as

pálpebra baixem

$\&$ meu amor por ti uma profanação consciente de eternas

estrelas de rapina” ( (OO jardim das delícias”, Um estrangeiro na legião, p. 95)

5.

"(...)

noite de meninos com corações brancos

(...)” (“Matéria \& clarineta”, Um estrangeiro na legião, p. 101)

É possível perceber a diferença no modo como os adolescentes são tematizados no primeiro livro, de modo menos erotizado do que em Mala na mão \& asas pretas. Embora a temática do sexo esteja presente em todos os volume de obras reunidas, é neste segundo na qual ela é mais forte e marcada, como no livro Coxas, sex fiction \& delírios, que tem descrições de cenas de sexo explícitas. O trecho 2 é a epígrafe de um texto de Isaac Asimov que, não fosse o título dado ao poema, "O robot pederasta", não teria uma conotação sexual, contudo, colocado nesse contexto, o carícia gentil que o robot dispensa à criança se torna um carinho erótico; no trecho 4, o amor pelo jovem de 15 anos é uma "profanação consciente", ou seja, uma subversão do que é sagrado; no trecho 1 trata-se apenas da contemplação de lindos garotos sob a luz; o trecho 5 refere-se aos meninos que povoam a noite, com "corações brancos", ou seja, marcados pela pureza e pela inexperiência. O 
poema Piazza VI mostra como os garotos "rompem barreiras", mesmo "sem ler / Freud ou Villon”, o que faz com que esse impulso em investir com os limites é algo natural dos jovens, não é resultado de estudos ou contato com a cultura intelectual, é a rebeldia adolescente que, na poesia de Roberto Piva, é extremamente positiva, pois não aceita imposições de instâncias sociais que visam regulamentar o comportamento, e essa insubordinação gera uma difusão de energia transformadora "então em qualquer / terreno baldio / iluminam / vestem-se / no furação do amor humano”.

Vale ressaltar que os limites entre o desejo e o amor são diluídos, não se distingue o desejo sexual como atração física e o sentimento de afeto, carinho e intimidade, os dois se entrecruzam e se misturam, sem que isso seja uma contradição. O amor homoerótico, na poesia de Roberto Piva, é uma forma de subversão, de recusa a qualquer forma de enquadramento nos padrões, sejam eles políticos, religiosos, econômicos e sociais. No discurso piviano qualquer forma de sujeição é negada e combatida, frequentemente com a afirmação dos valores exatamente opostos. O homoerotismo dessa poesia não é só uma forma de insubordinação ao interdito cristão de relações íntimas entre os homens, mas sim aos interditos a toda forma de manifestação do desejo, por isso não é o amor entre quatro paredes, mas sim o amor professado e realizado publicamente, sem hipocrisia e sem segrego, como no poema inicial de Coxas sex fiction e delírios, "Eram 4 horas da tarde do mês de junho \& o sol batia no / topo do Edifício Copan suas rajadas paulistanas onde Pólen / \& Luizinho foram fazer amor \& tomar vinho". A família, nos moldes tradicionais, também é motivo de repulsa para o poeta, pois limita o comportamento dos seus membros, que devem seguir um certo modo de se portar e se apresentar perante os outros, sob pena de alguma forma de punição: 


\section{Apavoramento $\mathrm{n}^{\mathrm{o}} 2$}

quinze adolescentes de ambos os sexos foram chicoteados na bunda por batalhões da TFP que os insultavam enquanto trezentos rapazes \& moças da seita imperialista Igreja Católica cortavam rodelas de cebola \& colavam em seus olhos.

O poema Apavoramento $n^{\circ} 2$ encena uma punição aplicada a quinze adolescentes; não se sabe o que fizeram, mas o castigo é imposto por batalhões da TFP, sigla para Tradição, Família e Propriedade, organização católica e tradicionalista fundada em 1960 por Plínio Correia de Oliveira. Enquanto isso, rapazes e moças da "seita imperialista Igreja Católica" cortam rodelas de cebola e colam em seus olhos.

O título do poema dá continuidade, ou serve como exemplificação, do que foi colocado no final do primeiro poema do livro Coxas sex fiction \& delírios, "Os escorpiões do sol": "Uma vez implantadas as bases do Estado militarista na / América do Norte, uma série de acontecimentos comoveu / a opinião pública, os governantes, os militares, conduzindo / toda a classe dirigente do país a crises sucessivas de / apavoramento e histeria" (p. 53). A isso, seguem os poemas “Apavoramento no 1", “Apavoramento no 2", "Histeria $n^{\circ} 1$ " e "Histeria $n^{\circ} 2$ ". O trecho mostra que essas crises foram reações da classe dirigente do país na tentativa de manter o controle através do medo.

A organização TFP organiza-se por princípios básicos, facilmente encontrados atualmente no site da $\mathrm{TFP}^{12}$ : “A tradição autêntica afirma: o verdadeiro progresso não é destruir, mas somar, não é romper, mas continuar para o alto. É a soma do passado com um presente que lhe seja assim. Visa impedir que o progresso se torne desumano, odioso. A família gera necessariamente a tradição e a hierarquia social. Depauperar e enfraquecer a

\footnotetext{
${ }^{12}$ http://www.tfp.org.br/tradicao-familia-e-propriedade/por-que-tfp
} 
família destrói a cultura e a civilização impregnadas de tradições cristãs. É o ensinamento do Papa Pio XII. O fundamento da propriedade está na própria natureza do ser humano. Os direitos à liberdade, ao trabalho e ao fruto do seu trabalho, isto é, à propriedade nascem da essência do homem". A Igreja Católica, no poema, é uma seita imperialista.

A obra completa de Roberto Piva apresenta características muito semelhantes, ou idênticas, em momentos de produção poética diferentes. Esse poema, por exemplo, evoca muito do que já foi dito sobre o livro Um estrangeiro na legião, no que diz respeito ao embate que o sujeito trava para se desvencilhar dos valores impostos pelas ideologias dominantes, principalmente da Igreja Católica buscando, para isso, seguir uma performance oposta. O tema da piedade, que foi objeto de análise no capítulo anterior, é retomado aqui através dos rapazes e moças que cortam rodelas de cebola e colam em seus olhos. Sabe-se que a cebola, quando cortada, produz uma substância chamada ácido sulfênico que se transforma em gás quando a cebola é cortada, e essa substância, em contato com a umidade dos olhos, produz uma solução fraca de ácido sulfúrico, fazendo os pessoa que cortou a cebola produzirem lágrimas. O resultado, portanto, da ação dos rapazes e moças, à ação de cortar as cebolas e colarem em seus olhos seria, inevitavelmente, muitas lágrimas. Essas lágrimas são o resultado de uma combinação química, e não de nenhum outro motivo. No entanto, figurativamente a lágrima é associada à tristeza e também ao sentimento de piedade ao ver uma cena que nos entristece. Esses jovens da Igreja Católica devem apresentar comportamento que sejam impostos pelas formações ideológicas da igreja e, portanto, a piedade. Essa cena do poema pretende evidenciar o caráter obrigatório do dever ser, sem que isso necessariamente emane do querer, ou seja, não é um sentimento verdadeiro, pois não emana do sujeito, mas sim de obrigações. 
Já no primeiro livro, Um estrangeiro na legião, o poema "A piedade" enuncia "se eu fosse piedoso, meu sexo seria dócil e só se ergueria / aos sábados a noite”. O sexo comportado, dócil e restrito ao contexto conjugal também é, nesse contexto, uma forma de aprisionamento, como podemos ver no poema abaixo:

Poema XII

"ci riguardava come suol da sera guardare uno altro sotto nuova luna" Dante, Inferno, canto XV, "I sodomiti"

adolescentes violetas na porta do cinema.

Bar Jeca esquina da São João/

Ipiranga.

revoada de revoltados. maravilhosos. jamais capitular.

pijamas, família, tv doméstica: a

ordem Kareta se representa

a si mesma.

corpo doce-delicado-quente na manhã alaranjada.

o planeta entra na órbita do

coração.

O poema faz uma homenagem aos adolescentes revoltados, "maravilhosos", que não devem jamais render-se, ao mesmo tempo que faz uma crítica a "ordem Kareta", representada por "pijamas", "família e "tv doméstica". O "corpo doce-delicado-quente" também é uma referência ao adolescente, pois qualificações como doce e delicado são condizentes com o corpo mais jovem. 
A epígrafe do poema é do canto XV do Inferno da trilogia de Dante Alighieri, no qual ocorre a punição dos que foram violentos contra Deus, no qual se incluem os sodomitas, que pecaram contra a natureza da forma como criada por Deus, e cujo castigo é andar continuamente debaixo da chuva de fogo sobre o areal em brasa. No canto XV, Dante encontra-se no Inferno com o seu mestre Brunetto Latini, que cumpre a pena por sodomia. A parte do qual o trecho foi retirado faz parte desse encontro: "quando incontrammo d'anime uma schiera / che venian lungo l'argine, e ciascuna / ci riguardava come suol da sera / guardare uno altro sotto nuova luna; / e si ver' noi aguzzavan le ciglia / come 'l vecchio sartor fa ne la cruna” (ALIGUIERI, trad. por MAURO, I. E, 1998: 109/110) (De almas uma fileira ora aparece, / vindo de encontro a nós, beirando o dique, /a nos fitar como, quando entardece / no novilúnio, quem o olhar estique; / ou, como ancião costureiro aguçando / os cílios, que sobre a agulha se aplique). A epígrafe refere-se a um entardecer de Lua Nova, no qual um observador dirige-se ao observado com olhar aguçado, mesma posição na qual se encontra o enunciador do poema em relação aos adolescentes na porta do cinema, o que o coloca como observador externo, não participante dos acontecimentos, é um enunciador que contempla os adolescentes com admiração e encanto, pois os considera “maravilhosos" em sua revolta.

O homossexualismo como forma de subversão do sistema capitalista aparece explicitamente no "Manifesto utópico-ecológico em defesa da poesia \& do delírio" no qual, entre as 10 reivindicações "em nome da saúde mental das novas gerações”, está a seguinte:

“7 - Distribuição de manuais entre sexólogas(os) / explicando por que o coito anal derruba o Kapital” 
Sobre essa reivindicação, Fabio Weintraub, em conversa com Roberto Piva, questiona "E quanto aos seus manifestos? O coito anal derruba mesmo o capital?", ao que este explica:

"(risos) De certa forma, sim. Porque se todos forem homossexuais, acaba a mão-deobra. A não ser naquelas sociedades de Sade, em eu há a ilha onde algumas pessoas são designadas para a reprodução e, envergonhadíssimas, dirigem-se à heterossexualidade. Mas, se a sociedade inteira for homossexual, acaba a reprodução da mão-de-obra e, portanto, acaba o capital (risos). Não só o capital, a espécie humana. O que talvez fosse interessante. O herdeiro seria a onça pintada que, comovida, agradeceria (risos)". (COHN, Org, 2009: 132)

Na poesia de Roberto Piva, é necessário subverter todas as instâncias possíveis da vida humana e, para isso, as regras e as doutrinas devem ser combatidas nos níveis político, social, familiar, amoroso, sexual e religioso. 


\section{ESTRANHOS SINAIS DE SATURNO}

\subsection{Apresentação do volume}

As obras do volume 3, Estranhos sinais de Saturno, tem um caráter visivelmente mais místico, com uma temática xamânica, voltando para a busca pela espiritualidade e, dessa forma, aproxima-se de alguns poetas da natureza, desde românticos, como William Blake, a contemporâneos, como o poeta beat Gary Snyder. Este volume reúne os livros Ciclones, publicado em 1997, e os inéditos Estranhos sinais de Saturno e Sindicato da natureza, conjunto de manifestos, além de um compact disc contendo gravações de poemas lidos pelo seu autor.

Claudio Willer, em seu artigo "Alguns poetas da natureza, dos românticos aos contemporâneos"13, afirma que os poetas que fazem parte desse agrupamento denominado “poetas da natureza", no qual Piva está inserido, buscam dar à natureza um tratamento nãodecorativo, porém crítico. Nesse sentido, o autor mostra a sintonia de Roberto Piva a poetas como William Blake, que vislumbrava a unidade do homem e do universo, da consciência individual e daquela cósmica. Para Blake, assim como para Piva, a natureza é o cenário de manifestação do divino.

\subsection{A função sagrada da poesia e o xamanismo}

Seguindo a poética subversiva da sua poesia, o que chama a atenção nesse terceiro volume das obras reunidas é a extrema valorização da natureza, em oposição à cultura e à civilidade. A temática central do livro é, inegavelmente, a espiritualidade, porém isso não

\footnotetext{
${ }^{13}$ Revista Celuzlose, $n^{\circ} 8$
} 
se dá em forma de adesão aos valores cristãos, é uma busca espiritual que mistura elementos diferentes correntes filosóficas e religiosas, sendo que a predominante é o xamanismo.

O volume faz referências a estudos sobre o xamanismo, merecendo destaque especial os estudos do historiador das religiões romeno Mircea Eliade, em livros como Aspectos do mito e Xamanismo e ténicas arcaicas do êxtase, mas também aparece Jerome Rothenberg, logo na abertura de Ciclones, com uma citação de Etnopoesia no milênio, que é a seguinte:

O trabalho dos xamãs (curandeiros tradicionais: mestres do êxtase \& do transe, diz Mircea Eliade... os ténicos do sagrado) é explorar \& criar o extraordinário (o "maravilhoso" de André Breton \& dos surrealistas), explorar \& criá-lo por meio do transe \& pelo controle da língua \& do ritmo, \& assim por diante (porque ele, que controla o ritmo, escreveu alguém, controla).

Da perspectiva da consciência comum, este trabalho do xamã é desorientador, assustador, \& o próprio xamã (ele ou ela) frequentemente experimenta tudo isto como terror um pavor da morte \& da doença - curar o pavor da morte \& da doença - \& o pavor da loucura/psicose/alma, quando ele realmente nos aflige.

Através da intertextualidade mencionada, cria-se uma disposição de leitura, pois uma epígrafe ou citação inicial serve para criar um "tom” do que será dito a seguir. É através dela que a temática dominante no livro, nesse caso, é apresentada, ao mesmo tempo em que cria-se uma interdiscursividade, traçando um paralelo com os discursos possíveis que serviram de inspiração para a obra e com o qual ela dialoga. 
Antes do primeiro poema de Ciclones, anuncia-se "Tempo de tambor", seguido de uma epígrafe, em italiano:

Io vi ho insegnato l'estasi

divina del libero canto: quella che il dervis trova

nella vertigine della sua danza infernale

Enrico Cavacchioli

Algumas palavras chamam a atenção nesse pequeno trecho: "o êxtase divino", “dervixe" (um tipo de monge muçulmano) e "dança infernal”, que reiteram a temática da religiosidade e do xamanismo, que será ratificado em diversos momentos do livro, através de novos temas e novas figuras que serão construídas nos poemas. O "tambor" desempenhará um papel de destaque no livro, aparecendo várias vezes, e sempre relacionado a religião; o ritmo do tambor não só será o ritmo dos poemas, como também será relacionado a pulsação e a energia vital do ser humano e o ritmo do tempo.

Esse terceiro volume constrói-se sob algumas oposições básicas que se relacionam, são elas:

natureza VS cultura

não-humano VS humano

A partir dessas, outras oposições e relações se estabelecem sempre, de alguma forma, retomando-as ou podendo ser resumidas nos valores nela contidos. Há, nesse livro, um impulso de retomada aos "impulsos primitivos" do homem, sem que isso tenha qualquer tipo de denotação negativa, pelo contrário, são impulsos que, sendo restaurados, permitiriam um maior contato com as forças da natureza e a energia vital do ser humano 
que, segundo o poeta, se perdeu na sociedade industrial em favor de uma extrema racionalização e produtividade. Em outras palavras, a vida se tornou tão incrivelmente regrada e limitada que os seres humanos perderam contato consigo mesmos, com seu corpo, com seus pensamentos, anseios, vivendo automaticamente e sem ao menos ter a consciência disso.

Para Roberto Piva, assim como para a linguística saussureana, tudo é criado através da linguagem. A sociedade industrial, a qual o poeta quer se opor, se estruturou a partir de valores, regras e preceitos criados na e pela linguagem e que, portanto, só podem ser desconstruídos e ressignificados da mesma forma. É nesse contexto que a figura do xamã, análoga a do poeta, adquire importância, pois a experiência xamânica é, acima de tudo, uma experiência de construção de significação, como diria o poeta "é uma experiência de volta às origens da poesia. Os primeiros poetas foram xamãs, foram profetas, faziam poesias que relatavam os seus relacionamentos com espíritos tutelares, com os totens, com as forças incontroláveis da orgia dionisíca. E, principalmente, o caminho do coração, que é o caminho do xamã” (COHN, 2009, p. 98). Para a poesia desse volume, os poetas devem resgatar suas raízes xamânicas, como diria um trecho de um dos poemas mais conhecidos e citados desse volume, que diz:

"Quando nossos

poetas

vão cair na vida?

Deixar de ser broxas

pra serem bruxos? (pág. 43)

Para Piva, "não existe poeta experimental que não tenha vida experimental”, como ele gostava de dizer em entrevistas e palestras. Nesse sentido, para reinventar a linguagem, 
o poeta deve "cair na vida", o que, no contexto desse livro, significa entrar em contato com o mundo mágico, não no sentido fantasioso do termo, mas no sentido de oposição ao racionalismo extremo e o excesso de regras morais e comportamentais da sociedade. "Cair na vida" é a condição essencial para sua escrita, o que explica o tempo de intervalo entre seus livros, segundo ele próprio: "Eu fiquei doze anos sem escrever poesia, entre 1964 e 76. Escrever é um desgaste muito grande. Eu tenho de cair na vida, entre um livro e outro, para recolher experiências, para poder transformar alquimicamente a matéria-prima em pedra filosofal. Eu sou um curandeiro das palavras”. (HUNGRIA \& D’ELIA, Org. 2011: 94).

Assim como o xamã e o poeta são aproximados na poesia desse volume, também são a religião e a poesia, porém não a religião nos termos cristãos tradicionais, mas a religião que é resultado de uma experiência de proximidade entre o ser humano e as energias da natureza. Retomando a epígrafe de Enrico Cavacchioli, do começo de Ciclones, o objetivo último da religião e da poesia é o "êxtase divino", sendo que o êxtase é o "arrebatamento do espírito; enlevo; contemplação do que é divino, sobrenatural, maravilhoso" $"$. O êxtase é, portanto, o objeto de valor da poesia nesse terceiro volume, e não apenas o êxtase do poeta, mas também do leitor, a poesia deve conduzir ao êxtase, pois esse é o seu objetivo. O xamã e o poeta são os sujeitos dotados do saber-fazer, pois é através deles que a poesia se concretiza, e para adquirir esse saber-fazer, o poeta deve ter, anteriormente, passado por um percurso que o dotasse dessa competência, que é o "cair na vida", e poesia e o xamanismo seriam a configuração do poder-fazer, pois servem como instrumento para atingir o objetivo. Mircea Eliade, logo no início de sua obra Xamanismo e técnicas arcaicas do êxtase, define o xamanismo assim: "Uma primeira definição desse fenômeno complexo, e possivelmente a menos arriscada, será: xamanismo = técnica do

\footnotetext{
${ }^{14}$ Dicionário Priberam de Língua Portuguesa
} 
êxtase" (ELIADE, 1998: 16). No mesmo livro, em diversos momentos, Mircea Eliade reitera que o xamanismo não é uma doutrina homogênea como as religiões cristãs, por exemplo, mas sim uma mistura de diversos elementos que entram em jogo em determinada cultura, dependendo muito, além disso, da figura do xamã em particular. Segundo Eliade, o que há em comum em diferentes tipos de xamanismo, por assim dizer, é a capacidade do xamã de controlar o êxtase seu e dos outros:

Magia e magos há praticamente em todo o mundo, ao passo que o xamanismo aponta para uma 'especialidade' mágica específica [...] : o 'domínio do fogo', o vôo mágico etc. Por isso, embora o xamã tenha, entre outras qualidades, a de mago, não é qualquer mago que pode ser qualificado de xamã. A mesma precisão se impõe a propósito das curas xamânicas: todo medicine-man cura, mas o xamã emprega um método que lhe é exclusivo. As técnicas xamânicas do êxtase, por sua vez, não esgotam todas as variedades da experiência extática registradas na história das religiões e na etnologia religiosa; não se pode, portanto, considerar qualquer extático como um xamã: este é o especialista em um transe, durante o qual se acredita que sua alma deixa o corpo para realizar ascensões celestes ou descensões infernais. (ELIADE, 1998: 17)

\subsection{Poema "signos, selos \& sigilos}

signos selos \& sigilos

serpente solar serpenteando

a seta

solitudes

solo de sax santificando

o Satori 
O poema acima é o segundo poema do conjunto intitulado Hic habitat felicitas, no livro Ciclones. A princípio, o título do conjunto nos remete, novamente, ao tema da homossexualidade, pois "hic habitat felicitas" (em português, algo como "aqui mora a felicidade") foi uma inscrição encontrada em uma escultura de um falo na entrada de um bordel na antiga civilização de Pompéia, cidade do Império Romano tragada pelo Vesúvio. Como já foi dito no capítulo anterior, nas civilizações grega e romana, o olhar sobre a homossexualidade não era permeado pelas restrições morais da ideologia capitalista e cristã. O primeiro poema do conjunto Hib habitat felicitas reitera essa temática através do uso explícito do termo "glande”, em "deus fascinus / na soleira da porta / aponta / a glande rosada" (p. 46).

A ausência de letras maiúsculas, vírgulas, pontos finais são características comuns em grande parte dos poemas deste terceiro volume, assim como dos outros dois. No entanto, esse volume merece destaque em relação ao outros no que se refere à concisão dos poemas, pois dos três volumes, esse é o que apresenta poemas mais curtos. Aliás, vale ressaltar que entre Um estrangeiro na legião e Estranhos sinais de Saturno, houve um percurso de concisão, pois os poemas do primeiro volume eram, em sua maioria, mais longos, ao passo que foram diminuindo no segundo e ficaram ainda mais breves no terceiro, o que será melhor comentado adiante.

A princípio, as palavras parecem estar mais ligadas entre si pela sonoridade (significante) do que pelo conteúdo (significado), entretanto algumas aproximações podem ser traçadas para a compreensão do sentido do poema. "Signos", "selos" e "sigilos" parecem muito distintos, pois têm significados mais correntes distantes entre si, no entanto, nem sempre os usos mais frequentes são os evocados na construção do sentido. O dicionário Priberam de Língua Portuguesa oferece as seguintes definições: 
signo

(latim signum,-i,sinal,marca)

s. $m$.

1. Sinal ou símbolo de algo.

2. [Astronomia] Cada uma das doze partes do Zodíaco na esfera celeste.

3. [Astronomia] Constelação correspondente a cada uma dessas doze partes.

4. [Astrologia] Cada uma das figuras ou conceitos que representam a influência das doze partes do Zodíaco celeste sobre a vida ou a personalidade das pessoas.

5. Área de influência.

6. [Linguística] Unidade linguística que contém um significante (forma ou imagem acústica) e um significado (conceito).

7. [Música] Nome genérico das notas de música.

selo $|\hat{e}|$

s. $m$.

1. Sinete, chancela; carimbo; estampilha; cunho.

2. Marca estampada.

sigilo

(latim sigillum, $-i$, estatueta, sinete, selo, marca, sinal)

s. $m$.

1. Segredo.

2. [Pouco usado] Selo

A intersecção entre os três termos mostra que a recorrência semântica entre eles, até mesmo etmologicamente, reside no sema de marca distintiva, sinal. Essa recorrência semântica, em semiótica, constitui uma isotopia. Os três termos parecem estar conectados ainda a mais um, "solitudes" que, assim como os outros, está no plural, em oposição ao restante do poema, do qual estão isolados, pois "serpente solar serpenteando a seta" e "solo de sax santificando o Satori” são orações completas. "Solitudes" aproxima-se dessa isotopia inicial, na medida em que o isolamento ou reclusão voluntária marca um traço de diferenciação da pessoa que se isola das outras pessoas, ou seja, é uma pessoa que conscientemente se sente distinta de outras, valendo ressaltar que, em psicologia, solitude e solidão não são termos análogos, em vista que o segundo é uma busca por companhia que 
não encontra resultados, o que resulta em sofrimento, enquanto no primeiro, o sofrimento não é uma condição necessária.

Passando à oração "serpente solar serpenteando / a seta" há de se considerar, assim como os primeiros termos do poema, que seu sentido mais usual não é o que irá compor o sentido do poema. "Serpente" usualmente é usada para designar o animal pertencente à classe dos répteis ofídios, popularmente conhecidos como cobras; "solar" como algo referente ao sol, o que gera um estranhamento na sua junção com o primeiro termo, pois aparentemente as duas coisas não teriam uma aproximação semântica, "serpenteando" como uma extensão de significado representando o movimento da serpente e "seta" como um ponteiro que indica uma direção a ser seguida. Entretanto, uma primeira busca em dicionário revela que "serpente" e "seta" também são denominações de constelações da via Láctea, o que gera uma confluência de significados com “solar". Essa isotopia celeste não é exclusiva deste poema, mas é recorrente no livro todo e já está demonstrada no título do volume "Estranhos sinais de Saturno".

A constelação de Serpente (ou Serpens) é uma constelação do equador celeste, foi uma das constelações observadas por Ptolomeu. A constelação tem a peculiaridade de ser dividida em duas partes, separadas pelo Serpentário: Serpens Caput e Serpens Cauda. Assim como a maioria das constelações, há diferentes lendas que cercam a de Serpente, a mais popular é a lenda grega que afirma que a grande cobra simbolizaria os conhecimentos médicos de Asclépio, personagem mítico que havia apurado a prática da medicina ao ponto de conseguir ressuscitar mortos, descoberta feita ao matar acidentalmente uma serpente e observar outra ressuscitá-la, depositando no seu corpo uma certa planta. Atualmente, a 
serpente ainda é vista como símbolo de conhecimentos médicos, representando ideias de renovação e até mesmo imortalidade, devido às periódicas mudanças de "pele".

A constelação de Seta, também conhecida como Flecha, é muito antiga e também está associada a lendas de culturas distintas, mas principalmente da mitologia GrecoRomana. O mito mais popular e corrente é o de que a seta (flecha) teria sido disparada por Apolo como vingança pela morte de seu filho Asclépio (ao qual o mito da constelação de Serpente se refere) por Zeus; Apolo teria disparado as setas para matar os ciclopes que seguiam as ordens do líder do Olimpo. Outra lenda interessante, também de origem grega, afirma que a seta teria sido disparada por Eros em Zeus, o que provocou seu desejo pelo jovem Ganimedes; o que seria comprovado pela proximidade dessa constelação com a constelação de Águia, que representaria a ave na qual Zeus se transformou para possuir o jovem amante. Essa segunda lenda é particularmente interessante considerando o discurso da poesia de Roberto Piva que, como foi dito no capítulo referente ao livro Mala na mão \& asas pretas, tem como temática recorrente o homoerotismo.

A última oração do poema cria um cenário musical e místico com "solo de sax santificando / o Satori”, no qual a música sacraliza o momento de iluminação. Satori é um termo do budismo japonês que significa literalmente "compreender/entender", e indica um estado duradouro de profunda iluminação e expansão da consciência, no qual o indivíduo liberta-se dos conceitos de tempo, espaço e forma. Segundo Suzuki, em Introdução ao zen budismo, "o Satori é uma espécie de percepção interior - não naturalmente a percepção de um objeto específico, mas, por assim dizer, a faculdade de sentir a verdadeira realidade. É uma percepção de ordem mais elevada." 


\subsubsection{A Semiótica verbal e os anagramas}

No plano de expressão percebe-se uma regularidade sonora que se mantém durante todo o poema. O tratamento fonológico do poema não deixa de trazer dificuldades, como afirma Zilberberg (ZILBERBERG, 2006: 254), pois os sons dificilmente seguem uma regularidade exata, cabendo ao analista perceber as semelhanças entre os fonemas e os traços propagados ao longo de uma cadeia sonora. As considerações de Zilberberg sobre a questão da prosódia poética são traçadas com base no conceito de "anagramas", usado por Sausurre em seu ensaio não terminado "As palavras sob as palavras", no qual busca compreender a estrutura das aliterações no verso saturnino. $\mathrm{O}$ autor propõe uma abordagem rítmica do verso, em lugar da metrificação que, para ele, é um traço facultativo e não obrigatório, como havia sido "decretado por Jakobson”. A poética do verso, nessa proposta, no qual busca compreender a estrutura das aliterações no verso saturnino.

De fato, Saussure admitiu que a aliteração exigia um princípio organizador que a dispusesse em 'função' na acepção hjelmsleviana do termo. Se surgir uma função, abre-se um espaço de inteligibilidade que compreende:

Um nível substancial - próprio das variáveis manifestantes, dos formantes - regido, regulado, pela aliteração corriqueira.

Um nível formal - próprio das constantes manifestadas, dos funtivos - regido, regulado, pelo anagrama [...]

A hipótese anagramática corresponde, resumidamente, a ver no lexema anagramatizado um endograma que concentra os fonemas (ou, eventualmente, os traços) de convocação, em relação com um exograma que faz propagar os fonemas do endograma, 
os quais se tornam, por isso, fonemas (ou traços) de evocação: ou ainda, de acordo com a terminologia saussuriana, contravogais e contraconsoantes. (Zilberberg, 2006: 256 ).

Da forma como colocada por Zilberberg, é possível pensar que, na composição sonora de um poema, dividido em versos ou em partes, pode haver um endograma (fonema - ou traços- de convocação) e um exograma (fonema - ou traços - de evocação), ou seja, para compreender as regularidades geradas fonologicamente, é preciso desmembrá-los em partes que tornem essa harmonia mais evidente. Ao analisar o plano da expressão do poema "Larme”, de Arthur Rimbaud (ZILBERBERG, 2006: 254 - 276), Zilberberg busca as

relações anagramáticas verso a verso e, posteriormente, traça paralelos entre os versos. É um trabalho de extrema profundidade, buscando desvendar o funcionamento sonoro do poema de uma maneira muito acurada, ainda que o próprio autor afirme que sua pesquisa é apenas "propedêutica".

No poema em questão, algumas regularidades sonoras podem ser observadas, e sons de um termo que se propagam em outro termo, isto é, na terminologia determinada por Zilberberg, o equivalente ao endograma e o exograma, respectivamente. No entanto, isso não se dá verso a verso, um fonema pode se repetir no mesmo verso quanto em algum verso posterior. Vejamos as relações mais diretas, levando em conta a interação direta das consoantes:

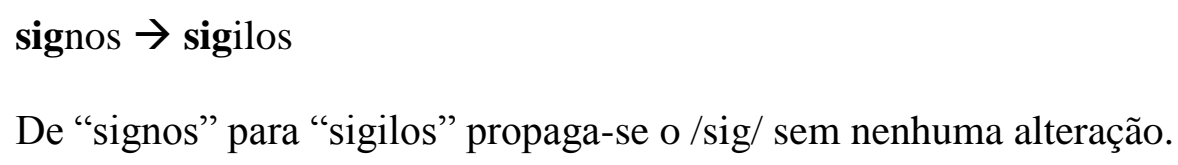


De "selos" para "solar", "solitudes" e“"solo" propaga-se os sons de /s/ + /vogal média-alta/ + /l/. Da passagem de /e/ para /o/ há um mudança em relação a anterioridade de /e/ para a posterioridade de /o/, assim como de arrendondamento, pois /e/ é uma vogal nãoarredondada enquanto /o/ é arredondada. No entanto, propaga-se o traço /médio-alto/, que pode ser também chamado de meio-fechado, referente à altura da língua que é dividida numa escala de quatro graus, e na qual /e/ e /o/ ocupam a mesma altura.

\section{serpente $\rightarrow$ serpenteando}

De “serpente" a "serpenteando" propaga-se, essencialmente, o /ser/, porém vale apontar que "serpente" encontra-se inteiramente reproduzida sonoramente em "serpenteando".

\section{seta $\rightarrow$ santificando $\rightarrow$ Satori $\rightarrow$ sax}

O trio "seta", "santificando" e "Satori" merece um detalhamento maior nas operações que ocorreram para a propagação dos traços fonológicos. A princípio, se estabelece que, em "seta", "santificando" e "Satori", ocorre /s/ + /vogal/ + /t/, ainda que, ortograficamente, "santificando" se inicie com "sant", sabe-se que, fonologicamente, ocorre a nasalização da vogal anterior /a/, que é um processo fonológico bastante comum no português, principalmente quando a consoante seguinte é uma oclusiva, como no caso do /t/ de "santi”, o que resulta no som /sãt/

Em "sax", mantém-se o /s/ + /a/, porém a consoante é diferente, no entanto, preserva traços fonológicos do /t/; nesse caso, portanto, a consoante muda, mas seus traços são os mesmos. O consoante final de "sax" é chamado, pela fonética, de africada, que é um tipo de som que une dois diferentes modos de articulação em sequência: uma oclusiva seguida de 
uma fricativa. Fonologicamente, o /t/ e o /ks/ apresentam em comum os traços [+ consonantal], [-soante], [-contínuo] e [+coronal], o que mostra que a regularidade sonora do endograma é preservada pela propagação de traços fonológicos.

Entre as vogais, têm-se /é/, /ã/ e /a/, nas quais a altura da língua vai de média-baixa em /é/ para uma posição intermediária entre média-baixa e baixa em /ã/ para baixa em /a/; em relação a posição da língua vai-se de anterior em /É/ para central em /Ã/ para anterior novamente em /A/; por fim, entre todas mantém-se o traço de não-arredondamento.

Ainda que se tenha separado os termos em grupos pela maior proximidade das consoantes, pode-se depreender, a partir da análise apresentada, uma forma simplificada do anagrama que se propaga por todo o poema, que é a construção /s/+ /vogal/ + /consoante/.

Embora até aqui a análise anagramática tenha se desenvolvido sobre o fonema, objeto de estudo da fonologia, talvez seja possível pensar em relações que acontecem no nível do fone, objeto de estudo da fonética, que são as unidades mínimas discretas dos sons, compostas por traços que se combinam. Essa separação corresponde à substância da expressão e à forma da expressão, na terminologia Hjelmslev:

Hjelmslev (1973) divide a língua em dois planos: expressão e conteúdo. A expressão corresponde ao significante e o conteúdo, ao significado. Hjelsmslev também afirma que cada um desses planos contém uma substância e uma forma. Há uma substância da expressão e uma forma da expressão (e o mesmo se dá com o conteúdo). Se pensarmos nas línguas faladas, a substância da expressão são os sons propriamente ditos, a forma da expressão é o recorte e a organização destes sons num sistema. Podemos então dizer que a fonética opera com a substância da expressão e a fonologia, com a forma da expressão (FIORIN Org, 2004: 10). 
A análise fonética lida com as características físicas e fisiológicas envolvidas na produção de um som e, com isso, abarca as diversas possibilidades de realização desse mesmo som, enquanto a fonologia estuda as relações entre os sons, como a sua variação permite a distinção de significado, e seu funcionamento no interior de uma língua. No português brasileiro, por exemplo, pode-se pronunciar o som central de "porta" como o /r/ paulistano ou como o /r/ caipira, isso representa um fone diferente, pois não são sons produzidos no mesmo ponto de articulação; no entanto, fonologicamente, correspondem ao mesmo fonema, pois a diferença entre o /r/ paulistano e o /r/ retroflexo caipira não representa uma distinção de significado. Para a análise do poema em questão, considerarse-á a produção fonética mais comuns dos sons da língua portuguesa.

Os compostos anagramáticos são: /s + vogal + g/, /s + vogal + 1/, /s + vogal + r/, /s + $\operatorname{vogal}+\mathrm{t} / \mathrm{e} / \mathrm{s}+\operatorname{vogal}+\mathrm{x} /$. Foneticamente, as consoantes são classificadas pelo ponto de obstrução do ar, chamado ponto de articulação, e o modo como o ar é obstruído, o modo de articulação, além da vibração ou não das cordas vocais. A partir desses critérios, o /s/, som que se mantém estável em todos os constituintes, é fricativo (modo de articulação), alveolar (ponto de articulação) e surdo (ausência de vibração nas cordas vocais). Para as demais consoantes, tem-se o seguinte esquema:

\begin{tabular}{cc|c|c} 
& Modo de articulação & Ponto de Articulação & Sonoridade \\
{$[\mathrm{g}]$} & oclusiva & velar & sonora \\
{$[1]$} & aproximante lateral & alveolar & sonora \\
{$[\mathrm{r}]$} & tepe & alveolar & sonora \\
{$[\mathrm{t}]$} & oclusiva & alveolar & surda \\
{$[\mathrm{ks}]$} & africada & alveolar & surda
\end{tabular}


O modo de articulação é diferente em todas os sons, porém a regularidade no ponto de articulação é notável, com a única variação sendo o [g]. A diferença entre um som alveolar e um velar é que o primeiro é produzido com a ponta ou lâmina da língua contra a arcada alveolar (parte óssea atrás dos dentes superiores), e o segundo é resultado do movimento do dorso da língua contra o véu palatino (continuação do céu da boca). Considerando que o trato vocal é um contínuo e que não há pontos fixos de produção dos sons, velar e alveolar não são pontos de articulação muito distantes.

Todas essas análises servem para mostrar como a regularidade dos sons de um poema vão além da mera aliteração de sons, e estendem-se tanto à forma da expressão quanto à sua substância.

\subsection{O poema "arco-íris"}

O poema abaixo se encontra no começo do livro Ciclones. Nesse livro, assim como no conjunto do volume, a maioria dos poemas não tem título, assim como esse, e são compostos, com algumas exceções, de poucos versos iniciados por letras minúsculas e sem pontuação:
O arco-íris
é o colar do feiticeiro
que apaga o dia
com a mão direita
$\&$ inaugura a noite
com a mão esquerda 
O poema começa com a metáfora "o arco-íris é o colar do feiticeiro" que conecta isotopicamente os sentidos do "arco" e do "colar", pois ambos possuem em comum o traço de circularidade; o arco é a metade de um círculo, assim como o arco-íris apresenta um ângulo de $180^{\circ}$ em uma superfície horizontal, e o colar, adorno colocado em volta do pescoço, embora forme um círculo completo, tem-se apenas a visão de uma parte dele. Em termos visuais, pensando em um círculo dividido horizontalmente na metade por dois, o arco seria a parte de cima e o colar, a parte de baixo.

Instaurado o traço da circularidade, passa-se ao restante do poema, que reitera essa ideia. O feiticeiro apaga o dia com a mão direita \& inaugura a noite com a mão esquerda, ou seja, da mesma forma que o arco e o colar começam de um lado e terminam do lado oposto, o lado direito é oposto do esquerdo, assim como o dia é o oposto da noite. Só é possível opor duas coisas que apresentam alguma similaridade de base, portanto, por mais que direito-esquerdo e dia-noite sejam opostos, eles tem em comum também o traço de circularidade. O dia e a noite, por exemplo, representam uma gradação em relação a um período de duração de 24 horas, e um começa quando o outro termina e vice-versa. É interessante pensar também na escolha das palavras "apaga" e "inaugura" para designar o fim do dia e o começo da noite, o que dá a impressão de uma cena teatral, na qual o feiticeiro é quem comanda o espetáculo, apagando as luzes do dia e inaugurando a noite, cada um com uma mão. Em outro poema, aparece uma relação semelhante entre o dia e a noite: "poesia é desatino / abrindo a Noite / no excesso do Dia"; tanto a noite quanto o dia não são estados naturais da passagem do tempo, eles são regulados e controlados por algum sujeito. Nesse sentido, a noite e o dia não começam e terminam, eles são iniciados e encerrados por um sujeito que tem a energia e o poder para realizar isso. 
O feiticeiro representa o sujeito que tem o poder de apagar o dia, inaugurar a noite, criar energia e transformar a vida humana, em outras palavras, é o sujeito do fazer, pois é aquele que realiza as mudanças de um estado a outro, pois ele é dotado de um saber e poder fazer essa transformação. Em outros poemas, esse sujeito aparece como o xamã, o poeta ou o "menino curandero".

Inicialmente, duas palavras chamam a atenção: arco e colar. As duas, como já foi dito, apresentam uma semelhança em relação ao significado, que evoca o traço de circularidade. No entanto, os significantes /arco/ e /colar/ também podem ser aproximados de uma forma muito interessante. Separando os significantes em segmentos menores, chega-se a /ar/, /co/ e /co/, /lar/, o que evidencia que, com exceção do /l/ central em /colar/, os segmentos são iguais, mas estão em posições opostas, dessa forma:

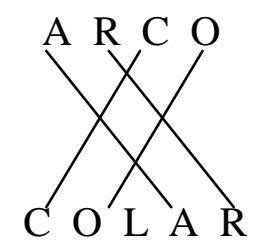

Considerando que, no plano do conteúdo, fala-se de circularidade, essa oposição entre os segmentos fonológicos dos dois significantes, não pode ser considerado aleatório, pois o movimento de inversão dos segmentos dos significantes ratifica ao traço de circularidade presente no significado.

A palavra arco-íris ressoa em todo o poema. Considerando primeiramente as vogais /a/ /o/ e /i/, percebe-se que elas permeiam o poema inteiro:

\section{O arco-íris \\ é o colar do feiticeiro que apaga o dia}




\section{com a mão direita \\ \& inaugura a noite \\ com a mão esquerda}

Pode-se pensar que, em termos de significado, o poema é dividido em três partes, cada uma composta por dois versos. A primeira parte seria composta pelos versos 1 e 2 (o arco-íris/ é o colar do feiticeiro), a segunda pelos versos 3 e 4 (que apaga o dia / com a mão direita), e a terceira pelos versos 5 e 6 (\& inaugura a noite / com a mão esquerda). A primeira faz uma afirmação geral e as outras duas confirmam e exemplificam essa afirmação. As partes 2 e 3 enunciam ações ao mesmo tempo opostas e complementares, o que ratifica o traço da circularidade; em cada uma dessas partes, determinadas palavras enunciam essa oposição, e essas palavras ocupam o mesmo lugar, cada uma em seus respectivos versos, que são: apaga x inaugura, dia x noite e direita x esquerda. Entre essas palavras, ocorrem quiasmos fonológicos interessantes:
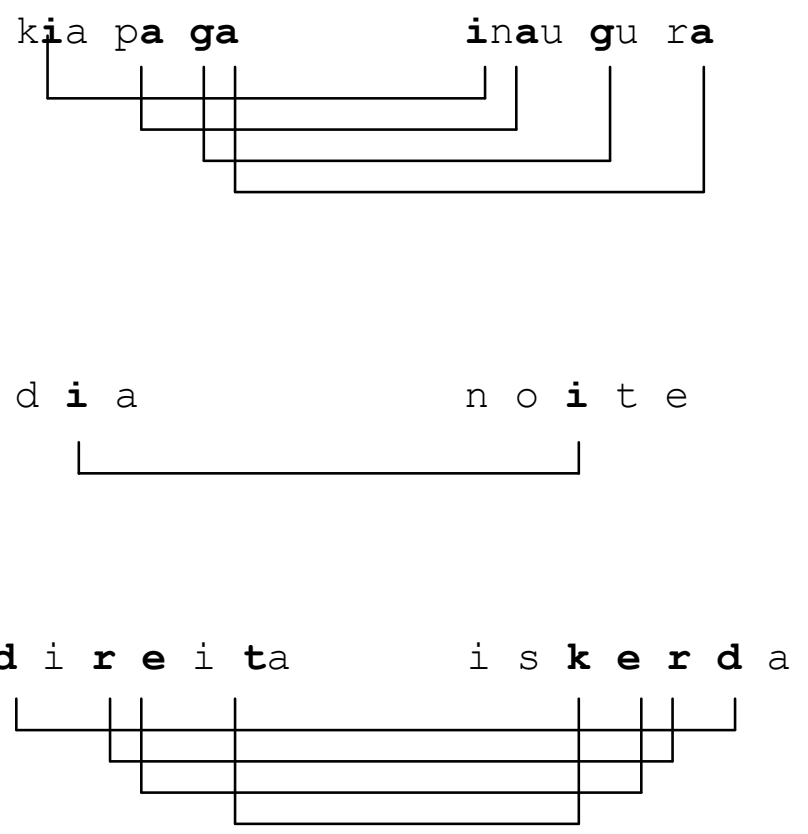
A proximidade entre /t/ e /k/, "direita" e "esquerda", se dá sobre o modo de articulação e a sonoridade, pois ambas são oclusivas surdas.

Seguindo o ritmo do primeiro verso, o acento dos demais recai sempre sobre a penúltima sílaba:
O arco-íris
é o colar do feiticeiro
que apaga o dịa
com a mão direita
\& inaugura a noite
com a mão esquerda

Roberto Piva é um poeta que integra o regime do poeta pregador. No entanto, definir a pertinência de um poeta em um regime não é o mesmo que criar um aprisionamento. Esse poema mostra que um poeta pregador, algumas vezes, pode criar engenhos poéticos semelhantes ou tão complexos quanto os de um poeta linguista, fazendo criações inventivas com a linguagem.

\subsubsection{A circularidade do Ciclone}

A isotopia de circularidade é algo já evocado pelo título do livro. Ciclone é um "turbilhão em que o ar se precipita em círculos espiralados para dentro de uma área de baixa pressão"15; o título do livro está no plural, o que intensifica ainda mais essa circularidade, isto é, não é apenas um ciclone. O prefácio do livro é um aforismo do poeta Malcolm de Chazal:

\footnotetext{
${ }^{15}$ Dicionário Priberam de Língua Portuguesa
} 


\section{La volupté}

Est

Au centre

Du Cyclone

Des sens

A tradução livre desse aforismo seria "a volúpia está no centro do ciclone dos sentidos" que, novamente, nos remete ao ciclone e à circularidade. A introdução dos "sentidos" evoca um novo sentido para o "ciclone", que deixa de ser um fenômeno da natureza e constitui uma metáfora. Em outras palavras, o significado de "sentidos" acresce uma tematização mítica à tematização prática, portanto, novos semas que configuram o sentido de "ciclone", além da circularidade, serão selecionados. Partindo da definição dada acima, "turbilhão", que não só contém o traço de circularidade, mas também de agitação e turbulência, pode ter seu sentido ampliado para a compreensão da metáfora "ciclone de sentidos", pois é possível considerar que há, no sentir e nos sentidos, algo que causa inquietação ou turbulência. Dessa forma, o "ciclone dos sentidos" é a própria agitação dos sentidos em determinado momento ou situação, que interfere na forma como um sujeito percebe o mundo. Ao centro disso está a volúpia, o prazer, que são uma causa de agitação, o que, a essa altura não é novidade, pois a centralidade do prazer como instrumento de libertação na poesia de Roberto Piva é reiterada em toda a sua obra.

O título "Ciclones", portanto, evoca diretamente temas referentes a circularidade e a movimentação, o que se confirma ao longo do livro através de diferentes temáticas e figuras. O primeiro poema do livro nos diz o seguinte: 
esqueleto da lua

o tempo

tambor tão frágil

vomitando a noite

Nesse poema inaugural, aparecem elementos que seguirão presentes em todo o livro: uma referência a um corpo celeste (a lua), o tambor e uma fase do ciclo de um dia (a noite). A lua, assim como diversos outros corpos celestes, aparecerá em grande parte do livro, como será mostrado a seguir. O tambor, também uma figura circular, como gerador do ritmo e da movimentação de esferas da vida humana, também será retomado inúmeras vezes, e a noite, integrante do ciclo da passagem dos dias, seguirá como parte do percurso figurativo do livro como um todo. Logo de início, portanto, o livro já enuncia sua temática e suas figuras principais.

O tambor é uma das figuras mais recorrentes do livro, não só como instrumento musical, mas como objeto ritualístico, além de ser também uma figura da circularidade. $\mathrm{O}$ tambor é a figura representante do ritmo da vida, da passagem do tempo, da batida do coração, dos passos trilhando um caminho, da batida das asas dos pássaros, enfim, tudo que tem movimento é regido pela batida do tambor, que é o instrumento do xamã, sujeito do saber, do poder e do fazer, pois é aquele que tem faz a intersecção entre o homem e a natureza, entre o humano e o não-humano.

\subsection{Algumas considerações sobre a figuratividade}

Denis Bertrand, em Caminhos de Semiótica literária (2003), nos oferece um valioso debate sobre o conceito de figuratividade e sua concepção para a teoria Semiótica francesa. Ao contrário de ser um termo designado apenas para falar sobre como as figuras de um 
texto fazem referência ao "mundo natural", o conceito de figuratividade gera um debate mais complexo.

O modelo de análise do sentido adotado pela Semiótica baseia-se na autonomia da língua como sistema, não permitindo, assim, que se trace uma relação direta entre um signo do texto e um "referente" do mundo, pois este não é uma grandeza linguística, portanto está fora do sistema. Bertrand esclarece essa questão ao dizer que "o domínio extralinguístico que tal conceito designa cede lugar a uma abordagem fenomenológica das relações entre o discurso e o mundo da percepção. Sua relação não é entendida como simples designação (as palavras designam as coisas), mas antes como correlação entre duas semióticas. O mundo natural, do 'senso comum', na medida em que é logo de saída instruído pela percepção, constitui em si mesmo um universo significante, ou seja, uma semiótica. Ver não é apenas identificar objetos do mundo, é simultaneamente apreender relações entre tais objetos do mundo, para construir significações” (BERTRAND, 2003: 159).

O que é considerado como um "referente" do mundo pelo senso comum é, na verdade, uma semiótica. A análise de um texto deve mostrar como se relacionam essas duas semióticas, a da língua e a do mundo natural, pautando-se não mais nas ideias de que textos com referentes reais ou imaginários, mas no regime de veridicção instaurado pelo texto, que são as relações entre ser e parecer, ao qual o leitor pode aderir ou não. O quadrado da veridicção é construído pela combinação dos valores de ser e parecer e de suas negações. Esse modelo, criado por Greimas, foi alvo de críticas e debates entre autores que propuseram uma maior gradação entre os pólos do quadrado, com o intuito de que ele tivesse um alcance maior. Bertrand reproduz esse modelo, com os termos iniciais propostos por Greimas, assim como a denominação dada subsequentemente por Per Aage Brandt, em itálico: 


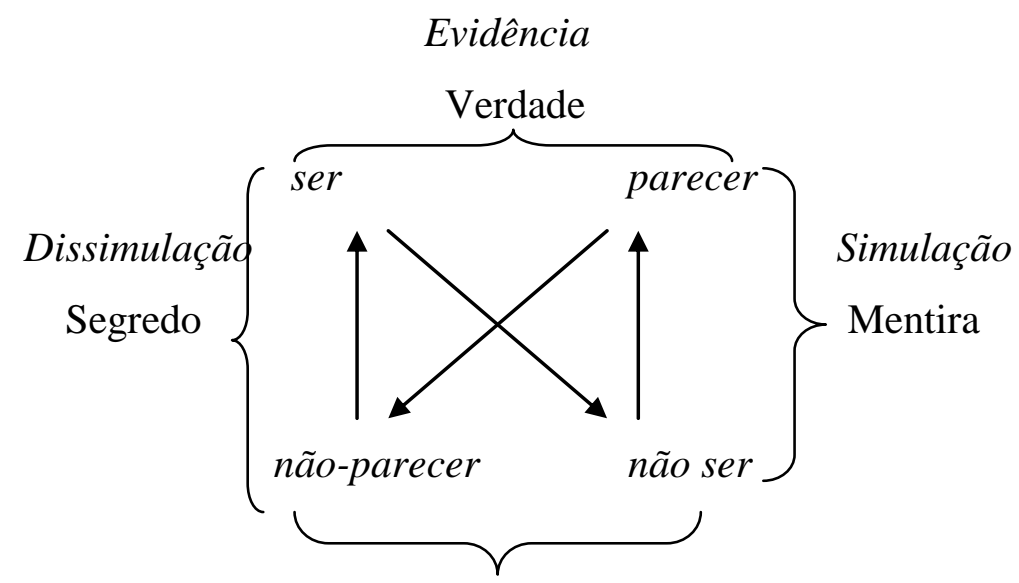

Falsidade

Não-pertinência

(BERTRAND, 2003: 243)

A problemática referente ao ser e ao parecer está ligada ao contrato fiduciário de veridicção, que se assenta sobre o /crer/, modalidade que evidencia a as fontes fenomenológicas da significação figurativa, ou seja, a dimensão perceptiva e sensorial. “A apreensão da figuratividade dos textos já não se volta para a posterioridade dos efeitos de sentido produzidos e sua estruturação; agora, ela está dirigida para o nascedouro da figurativização, para as próprias condições daquilo que o fundador da fenomenologia, E. Husserl, denominava 'função figurativa', isto é, 'o parecer da' cor, 'da' forma, etc, que se compõe com outros elementos na percepção para constituir 'a unidade de apreensão' sensorial das coisas". (p. 235-236). A modalidade do /crer/ é central no que diz respeito a como o texto é apreendido e interpretado, pois sua isotopia figurativa cria um efeito de sentido, que pode ser de realidade, de irrealidade ou de surrealidade.

Para analisar os desafios veridictórios da figuratividade, Bertrand vale-se do texto "Intervenção", de Henri Michaux, no qual o enunciador afirma que, por puro tédio, estando numa cidadezinha litorânea, resolve intervir na natureza e na vida cotidiana das pessoas, "introduzindo" camelos em paisagens da cidade. Com esse texto, o autor quer mostrar que, 
para que o leitor apreenda o sentido do texto, deve compreender o efeito de sentido que ali está sendo criado, ainda que este efeito de sentido seja de "desrealização", na qual o/crer/ é abalado.

A figuratividade está ligada a valores sociais, sendo que um texto, o de Michaux, por exemplo, pode colocar esses valores em suspenso, pois a apreensão do sentido é anterior aos valores sociais nele investidos. Para Bertrand, "esse processo geral da axiologia que pressupõe a intervenção do sensível pode ser comparado à tese segundo a qual as relações entre estética e ética, e mais precisamente, a subordinação da segunda à primeira, seriam firmadas na resensibilização dos valores. Assim, escreve J. Fontanille ${ }^{16}$ : 'Para desestabilizar as normas morais ou inventar outras, é necessário recomeçar pelo sentir, captar esse momento em que a escolha é tornada sensível e bela, e basear-se, não sobre o que o sujeito sabe da axiologia [...], mas sobre o que ele percebe dela nos objetos'. É assim que o mundo de valores retoma contato com a emergência sensível das formas significantes, reencontra seu foco fundador com o surgimento do sentido na percepção, e liga-se de fato ao plano de fundo fenomenológico que lhe condiciona o advento. Eis a primeira justificativa da intervenção: remontar até a percepção em si própria, para agir sobre o mundo dos valores coletivos.” (p. 247).

Essas reflexões sobre a figuratividade serão centrais para a compreensão do livro Estranhos sinais de Saturno.

\subsubsection{A figuratividade no volume Estranhos sinais de Saturno}

${ }^{16}$ FONTANILLE, J. "Présentation" ao dossiê "Les formes de vie". RS/RI, Recherches Sémiotiques/Semiotic Inquiry, Association canadienne de sémiotique, v. 13, n. 1-2, p. 6, 1993 
O terceiro livro da coletânea de obras reunidas, Estranhos sinais de Saturno, contém os livros Ciclones, Estranhos sinais de Saturno e Sindicato da natureza. Considerando inicialmente Ciclones e Estranhos sinais de Saturno, uma primeira leitura mostra que os livros são altamente figurativos, e após algumas leituras torna-se evidente o fato de que há algumas figuras que são muito recorrentes, estando presente em uma quantidade muito grande de poemas.

Inicialmente, considerou-se que as figuras mais recorrentes seriam de elementos da natureza em geral, árvores, rios, animais, etc, no entanto, uma maior atenção mostrou que havia, nessas figuras, algo em comum mais específico do que somente seres parte da natureza. Há uma fixação pelas seguintes figuras: lua, sol, céu e astros/estrelas. Essas figuras têm em comum o fato de todas serem elementos do que se pode denominar como “celeste". A recorrência dessas figuras instaura, portanto, uma isotopia figurativa.

Com o intuito de mostrar como a repetição dessas figuras se dá a todo momento, foi feita uma catalogação de todas as ocorrências, reproduzida abaixo.

\section{Lua:}

- “esqueleto da lua" (p. 23)

- "luas caiçaras /vigiadas / por ovnis sonâmbulos" (p. 31)

- "luz caminhando sobre / o luar" (p. 35)

- “divindade lunar” (p. 38)

- "minha mão / dança / no corpo do garoto lunar" (p. 39)

- "gestos-síntese / de sol \& lua" (p. 71)

- “a lua me apalpa o corpo" (p. 83)

- "René Crevel menino vidente / bebeu morte num pedaço / de lua em chamas" (p. 107)

- "um corpo lunar penetra no / quarto saído do mar" (p. 109) 
- “onde o Inferno está amarrado / onde o Paraíso voa com a Lua” (p. 120)

- "da minha janela da lua / vejo cidades que / sufocam no cimento" (p. 125)

- "o mistério lunar da menina / lésbica" (p. 127)

- "Poemas-flechadas / perfurando planetas queimados / vivos / lua fogo Sol” (p. 135)

- "linguagem de pássaro / lua de hemoglobina" (p. 142)

- "é o tempo do crime / \& sua prova / a caveira que ri / na noite vermelha / a explosão demográfica / \& a fome a galope / é o Sol mudo / a Lua paralítica / Drácula janta na esquina" (p. 148)

\section{Sol:}

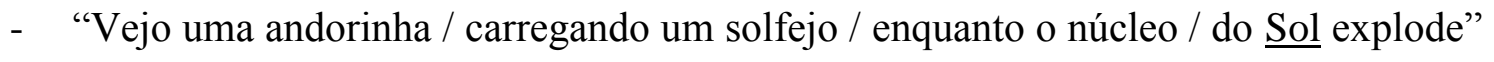
(p. 33)

- "serpente solar serpenteando / a seta" (p. 47)

- "planta do incesto / do sol com as / águas (p. 55)

- "neste dia / o sol é transparente / céu erótico aberto / com olhos de borra / de vinho / o brilho solar canta" (p. 56)

- "eu caminho seguindo o sol / sonhando saídas / definitivas da / cidade-sucata" (p. 58)

- "o mundo solar / está mobiliado / por olhos / de garotos com / almas de pétalas" (p. 66)

- "gestos-síntese / de sol \& lua" (p. 71)

- " sol ao sul da represa" (p. 81)

- "Menino-acauã dançando / ao sol estrangeiro" (p. 100)

- "sombra selvagem do crepúsculo / com o sol turquesa" (p. 103)

- "o URUBU-REI louco de ciúmes engoliu inteiro / o HERMAFRODITA DE JADE / quando o sol sem luz soprou seu planador / orgiástico no aeroporto" (p. 132)

- "Poemas-flechadas / perfurando planetas queimados / vivos / lua fogo Sol” (p. 135)

- "Mitra Sol invictus / nos corredores energéticos" (p. 141)

- "na entrelaçada pista / das nuvens / onde um sol retorcido / gira no grito do azul" (p. 147) 
- "é o tempo do crime / \& sua prova / a caveira que ri / na noite vermelha / a explosão

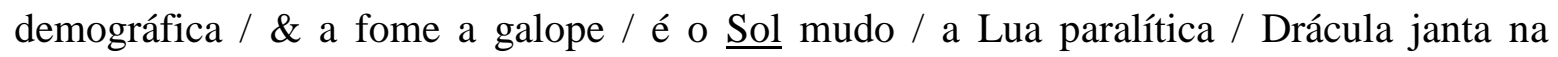
esquina" (p. 148)

- "vento de seda / sol se transformando / em pássaro" (p. 155)

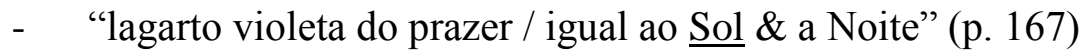

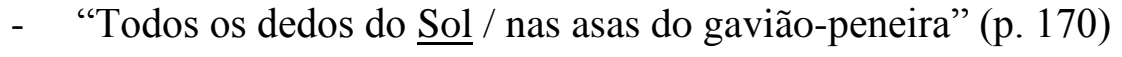

\section{Céu:}

- " "no olhar do garoto / que dança / no céu chapado" (p. 25)

- “céu erótico aberto" (p. 56)

- “o deserto atravessa o / céu" (p. 56)

- " "necessito cometas / no céu Caiçara / onde plana o / falcão mateiro" (p. 60)

- "chega o vento / a caixa do céu / se abre” (p. 70)

- "ilha falando do refluxo / \& da língua azul da praia / cabeça no céu / no deserto violeta sem espelhos" (p. 78)

- "canoas do Amazonas / no olho-peiote / no céu à queima-roupa" (p. 89)

- “O verão urra no céu rosa” (p. 99)

- “coração que perdeu o céu” (p. 107)

- "estrelas no céu curandero / poemas portadores da peste" (p. 151)

- "aviões cabeludos arrastam / o céu na direção / do universo" (p. 155)

- “céu esculhambado" (p. 170)

\section{Astros/estrelas:}

- “dinastia astral / reis exteriores" (p. 31)

- " "estrela do norte / flor de filigrana / no nervo do / poente" (p. 55)

- " “estrela fiel na chama do coração" (p. 64)

- “ “estrelas em prontidão / relâmpagos / temperam / a cerveja dionisíaca” (p. 66)

- "Eu atravessei manguezais / \& estrelas" (p. 67)

- "Que você conheça / a estrela da loucura” (p. 68)

- "a estrela / no olho às / vezes / é o / coração que bate" (p. 70)

- “estou nu / de pé na primeira estrela / recebendo o beijo / do andrógino" (p. 83) 
- "corpo de garoto por onde / passa o Império Romano / sangue onde navegam piratas, / estrelas turvas, bosques, telescópios" (p. 109)

- “contemplar nas estradas de topázio / o anzol das constelações (p. 122)

- “estrelas no céu curandero / poemas portadores da peste” (p. 151)

- “duas sanfonas se / descabelam numa / enxurrada de estrelas" (p. 153)

- "estrelas loucas / deusas orquídeas" (p. 157)

Essa isotopia figurativa do celeste, longe de criar o efeito de realidade, cria um efeito de surrealidade, pois as figuras aparecem como parte integrante de um discurso que, de fato, busca esse sentido, pois os significados dessas figuras são colocados lado a lado com outros significados que não fazem parte do mesmo universo semântico. Dessa maneira, o enunciador pode construir imagens absurdas, dizer que atravessou manguezais \& estrelas, há estrelas loucas, um coração perdeu o céu, o céu se torna erótico, a caixa do céu se abre, o Sol possui dedos e pode se transformar em pássaro, o núcleo do Sol explode, o enunciador caminha seguindo o sol, a lua apalpa o corpo, um corpo lunar penetra no quarto, a lua tem janela, e outras inúmera imagens surreais.

Para compreender esse efeito de sentido, é preciso retomar algumas considerações sobre xamanismo. A abertura de Ciclones contém um excerto de Etnopoesia do milênio, de Jerome Rothenberg, que é a seguinte:

O trabalho dos xamãs (curandeiros tradicionais: mestres do êxtase \& do transe, diz Mircea Eliade... os ténicos do sagrado) é explorar \& criar o extraordinário (o “maravilhoso" de André Breton \& dos surrealistas), explorar \& criá-lo por meio do transe \& pelo controle da língua \& do ritmo, \& assim por diante (porque ele, que controla o ritmo, escreveu alguém, controla). [...] 
Mircea Eliade, em seu livro Xamanismo e técnicas arcaicas do êxtase define, resumidamente, o xamanismo exatamente como uma técnica de êxtase, que é um estado de arrebatamento do espírito, enlevo, contemplação do que é divino, sobrenatural, maravilhoso. A experiência do xamã, por sua vez, consiste no seguinte:

As técnicas xamânicas do êxtase, por sua vez, não esgotam todas as variedades da experiência extática registradas na história das religiões e na etnologia religiosa; não se pode, portanto, considerar qualquer extático como um xamã: este é o especialista em um transe, durante o qual se acredita que sua alma deixa o corpo para realizar ascensões celestes ou descensões infernais. (ELIADE, 1998: 17).

O xamã é, portanto, um especialista nas técnicas de êxtase, período no seu qual sua alma deixa o corpo para realizar "ascensões celestes" ou “descensões infernais". Já foi dito anteriormente que o discurso do livro cria uma aproximação entre o trabalho do xamã e o trabalho do poeta. A partir disso, é possível entender a figuratividade da qual se falou acima. No poema Joãozinho da Goméia aparece "basta de poesia e religião que não conduza ao êxtase".

A reiteração das figuras da ordem do celeste busca criar um efeito de surrealidade que pretende fazer parecer que o enunciador, que nesse caso é colocado como poeta (não como o poeta Roberto Piva, mas ocupando o papel social de poeta) assim como o xamã, está em êxtase, portanto está licenciado para realizar transações entre o mundo terrestre e o celeste. $\mathrm{O}$ enunciador quer, portanto, fazer crer que ele é como o xamã para, assim como este, ter um poder criador. Nesse sentido, é criado a surrealidade, que é parte do êxtase, no entanto, a intenção é que esse êxtase seja tido como real. Pode-se pensar que é criado um 
efeito de surrealidade dentro da realidade: a surrealidade está no êxtase do xamã/poeta, enquanto a realidade é que êxtase deve parecer ter acontecido, por isso as figuras do celeste são reiteradas, para construirem esse efeito, pois o poeta enunciador deve mostrar, através dessas figuras que fez "ascensões celestes". Em suma, o enunciador quer parecer o xamã em êxtase, para isso se vale de figuras celestes, elementos que integram o êxtase xamânico. Não se pode esquecer também de pensar que, de alguma forma, isso já está presente no título Estranhos sinais de Saturno, pois tanto para poder receber quanto para poder enviar sinais de Saturno, que é um elemento celeste, seria necessário o estado de êxtase.

Publicada originalmente na revista Cult, em maio de 2000, Roberto Piva concedeu uma entrevista a Fabio Weintraub, na qual fala um pouco sobre a sua visão de arte, que reforça as afirmações feitas acima. Ele diz:

Quanto ao parentesco entre arte e loucura, acho que o "desregramento de todos os sentidos", de que falava o Rimbaud, refere-se não propriamente à loucura, mas a um estado de transe. Um estado de transe xamânico, porque Rimbaud era um alquimista, um xamã avant la lettre, que propõe mesmo à alucinação da palavras; o termo é dele. Os artistas, como afirma Joseph Campbell, são os xamãs da sociedade contemporânea. (COHN, Org. 2009:127)

\subsection{Natureza X cultura}

Assim como no primeiro volume, no qual a oposição dos valores liberdade $\mathrm{X}$ opressão serviam como base para a interpretação de muitos poemas, nesse volume uma oposição de base também pode desempenhar esse mesmo papel. Trata-se do par natureza X cultura, sendo que natureza, no contexto do livro, é comumente discursivizada como pertencente à ordem do "não-humano". As figuras do celeste também são, essencialmente, parte integrante do campo da natureza. A cultura aparece principalmente discursivizada 
como a sociedade industrial, principalmente a cidade, no caso a metrópole de São Paulo. Para o discurso do livro, o avanço tecnológico, o aumento e desenvolvimento das cidades não é algo positivo, mas sim algo que está tornando os seres humanos cada vez mais distantes das suas origens e da sua essência, enquanto a natureza e o não-humano é o que se deve buscar para restaurar a ligação com o meio-ambiente. Portanto, na oposição natureza X cultura, a primeira é euforizada enquanto a segunda é disfórica.

No poema A oitava energia, enuncia-se "que você conheça manguezais / \& realidades não-humanas / que são a essência da poesia". Para o discurso desse livro, portanto, a essência da poesia está além do conhecimento sobre o ser humano, pelo contrário, ela reside nas realidades não-humanas.

Muitas vezes tem se afirmado erroneamente que Roberto Piva era um poeta urbano, e que o descontentamento com a cidade só pode ser percebido neste terceiro livro. Contudo, ainda que o cenário dos poemas possa muitas vezes ser a cidade, esse espaço não é visto de forma positiva, o que se torna mais evidente neste livro, mas não deixa de ser uma afirmação verdadeira para todos os volumes. Ele mesmo, em entrevista, afirma isso: “Paranoia não é um poema urbano, é um poema contra o urbano. É um pesadelo, um delírio de uma pessoa que quer ser extraterrestre, quer sumir do mapa, quer pegar o disco voador das seis e partir para Alfa Centauro. É um poema em que vejo a falência da cidade, a sociedade industrial como uma vasta sucata, as ruas, os postes, os luminosos, tudo sucateado, a população sucateada, uma vasta sucata rolando no infinito do planeta" (COHN, 2009: 150). No poema III, de Estranhos sinais de Saturno, é afirmado, e ressaltado em negrito:

sou o poeta na cidade 
não da cidade

gosto das extensões azuladas das

últimas montanhas

contemplar nas estradas de topázio

o anzol das constelações

A respeito da oposição natureza x cultura, não se pode deixar de apontar o caráter ecológico do livro, no sentido de que há clara uma intenção de defender a maior proximidade, respeito e interação com a natureza, como mostra “eu caminho seguindo o sol / sonhando saídas / definitivas da / cidade-sucata". Não se trata apenas de euforizar a natureza como valor positivo, mas sim de defender a conservação dela e lutar "pelos direitos não-/humanos do planeta":

Nos anos 60 quando eu falava de Ecologia, a resposta das pessoas, que se amontoavam em bandos à direita \& à esquerda, era sempre uma profissão de fé na própria mediocridade. 'Com tanta gente passando fome, esse cara vem falar de natureza'. Como se a vida do cretino não dependesse exatamente do equilíbrio ecológico. Os trabalhadores têm a CUT, a CGT. A onça pintada não tem sindicato. Os rios não têm sindicato. $O$ mar não tem sindicato.

Eles terão agora o seu Sindicato neste cantinho. Crie você também com os colegas do bairro, do serviço, do clube, um SINDICATO DA NATUREZA. Nosso lema será sempre AMOR, POESIA \& LIBERDADE. A diversidade é a Verdade. Viva a diferença! Evoé!” (p. 178-179). 
Esse trecho extraído do livro Sindicato da Natureza mostra que o poeta se mantém no regime de poeta pregador, que busca integrar pessoas pare seguir os valores que pretende propagar.

A natureza é um valor que se relaciona, nesse livro, com o tema do sagrado, pois trata-se de uma visão de mundo que busca recusar as imposições da sociedade urbanoindustrial. É uma busca pelas forças da natureza que se afastaram dos seres humanos devido à doutrina capitalista que busca eficiência, racionalidade, produtividade e consumismo desenfreado. $\mathrm{O}$ discurso dessa poesia quer recuperar o estatuto de sagrado da natureza, que ocorreu não só com o capitalismo, mas também com o cristianismo, pois ambos estão intrinsecamente ligados. A ordem econômica, assim como a igreja é, portanto, diretamente responsável pela possibilidade de destruição da Terra que, nessa cultura, não tem o caráter de sagrado que tem em sociedades pagãs, na qual "os deuses sacralizando / todos os poros / da Terra" (p. 161).

Um dos manifestos de Sindicato da Natureza é capaz de resumir todas as ideias apresentadas acima, reiterando a ideia frequente em toda a obra de que é necessário não conformar-se:

Na última entrevista concedida à grande imprensa nos meados dos anos 50, o filósofo Martin Heidegger, perguntado sobre o que ele achava da Bomba Atômica, respondeu: "Qual delas? Esta de agora, ou aquela que explodiu há 2 mil anos?”. "Como assim?", perguntaram os jornalista atônitos. Heidegger acrescentou: "Pois quando Cristo falou: 'Meu reino não é deste mundo', ele detonou a primeira Bomba Atômica”.

De fato, a visão do mundo judaico-cristã, com seu Deus situado fora do Tempo \& do Espaço imobilizado na Eternidade, representa a concepção mais antiecológica de que temos notícia. "Meu reino não é deste mundo" significa que o mundo poderá estar entregue a todo tipo de devastação, quer por bombas, agrotóxicos, industrialização etc., 
pois para este ponto de vista o planeta Terra é um lugar de passagem, um "vale de lágrimas”, um lugar de expiação.

Não é sem motivo que os romanos perseguiam os cristãos sob a acusação de que eram ateus, pois não adoravam os deuses do panteão romano cada um deles representando uma paixão humana ou deusas agrárias representando a fertilidade \& a generosidade da Terra, como Ceres \& Cibele, sem falar de Baco (Dionísios para os gregos), deus da uva, do vinho \& dos bacanais que na Grécia \& Roma tinham um sentido religioso. Com o advento do Cristianismo, ocorreu a dessacralização do mundo, que para os pagãos era povoado de deuses. "O que for feito à Terra, recairá sobre os filhos da Terra”, diz o ditado dos índios peles-vermelhas, adoradores do peiote, do Sol, da Lua, do coiote \& do falcão. Amnésico \& anestesiado pela civilização urbana industrial, robotizado em seus sentimentos, limitado em sua visão pelos edifícios \& muros das cidades o homem moderno não sente mais a alegria cósmica \& pagã de participar de um nascer do sol de um crepúsculo, do silêncio das ilhas perfumadas, do instinto, da imensidão dos mares silenciosos, das estrelas. Reprimindo a criança que existe nele, o homem moderno aniquila os deuses do júbilo em seu coração. Deixa de improvisar sua vida, enquadrando-se na marcha uniforme da sociedade organizada \& vestida. (p. 181-182). 


\section{ConsideraÇões Finais}

\subsection{Roberto Piva, um poeta em desacordo}

Roberto Piva é um poeta pregador. Ele prega contra os valores que buscam aprisionar as pessoas, impedindo-as de manifestarem sua essência, bloqueando sua individualidade e cerceando seus direitos de serem diferentes, escandalosas, inadequadas, verborrágicas, intensas, malucas, drogadas, sensuais, sexuais, pagãs e todas as características que não são naturais e foram moldados pelas convenções sociais. O sujeito que vive na sociedade industrial capitalista cristã é modalizado pelo dever, e seu comportamento é regido por prescrições e interdições criadas por representantes da classe dominante para manutenção do status quo. O trabalho poético de Piva busca a rejeição de todas essas regras que foram criadas, é um projeto que busca não só a transgressão dessas regras, que é um não querer fazer, mas também a subversão dessas regras, que é querer fazer exatamente o contrário do que é imposto.

Roberto Piva é um poeta em desacordo. Em Um estrangeiro na legião, ele está em desacordo com a ordem social e econômica; em Mala na mão \& asas pretas ele está em desacordo com a ordem sexual e amorosa e em Estranhos sinais de Saturno ele está em desacordo com a ordem religiosa e espiritual. No documentário Assombrações Urbanas, ele afirma: "Eu fui poeta na impossibilidade absoluta de conformar-me".

Os títulos dos livros nos dão indícios de uma interpretação cronológica dos diferentes momentos poéticos da produção do autor. O título Um estrangeiro na legião remete a um sujeito que se sente diferente e deslocado da sociedade na qual se encontra, está em desacordo com a ordem estabelecida; já Mala na mão \& asas pretas expõe uma partida, através da figura da mala, e subvertendo a figura das asas angelicais, o título mostra 
o caminho da subversão, as asas pretas, que são o instrumento de fuga dessa legião que não está de acordo com os seus valores individuais; em Estranhos sinais de Saturno, o sujeito já partiu e encontra-se em outra dimensão planetária, da qual manda sinais. Trata-se de uma poética extremamente interligada, na qual temas, figuras, percursos narrativos e valores

repetem-se até que haja uma fixação. É nesse sentido que sentido que a característica do pregador se mostra em Roberto Piva. É necessário que haja rebelião e subversão dessa sociedade que, para ele, está cada vez mais doente e carente de imaginação e poesia.

Um manifesto-síntese de Mala na mão \& asas pretas, que resume muito do que foi dito sobre o poeta, para encerrar este trabalho com suas próprias palavras.

\section{Manifesto utópico-ecológico \\ em defesa da poesia \& do delírio}

\section{Invocação}

Ao Grande deus Dagon de olhos de fogo;

ao deus da vegetação Dionisos;

ao deus Puer que hipnotiza o Universo com seu ânus de diamante;

ao deus Escorpião atravessando a cabeça do Anjo;

ao deus Luper que desafiou as galáxias roedoras;

a Baal deus da pedra negra;

a Xangô deus-caralho fecundador da Tempestade.

Eu defendo o direito de todo ser Humano ao Pão \& à

Poesia.

Estamos sendo destruídos em nosso núcleo biológico, nosso espaço vital \& dos animais está reduzido a proporções ínfimas

quero dizer que o torniquete da civilização está 
provocando dor no corpo \& baba histérica

o delírio foi afastado da Teoria do Conhecimento

\& nossas escolas estão atrasadas pelo menos cem anos

em relação às últimas descobertas científicas no

campo da física, biologia, astronomia, linguagem,

pesquisa espacial, religião, ecologia,

poesia-cósmica, etc.,

provocando abandono das escolas pelas crianças, que

percebem que o professor não tem nada a

transmitir,

imobilizando nossas escolas no vício de linguagem \&

perda de tempo

em currículos de adestramento, onde nunca ninguém vai

estudar Einstein, Gerard de Nerval, Nietzsche,

Gilberto Freyre, J. Rostand, Fourier,

W. Heinsenberg, Paul Goodman, Virgílio, Murilo

Mendes, Max Born, Sousandrade, Hynek, G. Benn,

Barthes, Robert Sheckley, Rimbaud, Raymond

Roussel, Leopardi, Trakl, Rajneesh, Catulo, Crevel,

São Francisco, Vico, Darwin, Blake, Blavatsky,

Krucënych, Joyce, Reverdy, Villon, Novalis,

Marinetti, Heidegger \& Jacob Boehme

\& por essa razão a escola se coagulou em Galinheiro

onde se choca a histeria, o torcicolo \& repressão sexual,

não existindo mais saída a não ser fechá-la \&

transformá-la em Cinema onde crianças \&

adolescentes sigam de novo as pegadas da 
Fantasia com muita bolinação no escuro.

Os partidos políticos brasileiros não têm nenhuma preocupação em trazer a UTOPIA para o cotidiano.

Por isso em nome da saúde mental das novas gerações eu reivindico o seguinte:

1 - Transformar a Praça da Sé em horta coletiva \& pública.

2 - Distribuir obras dos poetas brasileiros entre os garotos (as) da Febem, únicos capazes de transformar a violência \& angústia de suas almas em música das esferas.

3 - Saunas para o povo.

4 - Construção urgente de mictórios públicos (existem pouquíssimos, o que prova que nossos políticos nunca andam a Pé ) \& espelhos.

5 - Fazer da Onça (pintada, preta \& suçuarana) o Totem da nacionalidade. Organizar grupos de Proteção à Onça em seu habitat natural. Devolver as onças que vivem trançadas em zoológicos às florestas. Abertura de inscrições para voluntários que queiram se comunicar telepaticamente com as onças para sabermos de suas reais dificuldades. Dessa maneira as onças poderiam passar uma temporada de 2 semanas entre os homens \& nesse período poderiam servir de guias \& professores na orientação das crianças cegas.

6 - Criação de uma política eficiente \& com grande informação ao público em relação aos 
Discos-Voadores. Formação de grupos de contato

\& troca de informação. Facilitar relações eróticas

entre terrestres \& tripulantes dos OVNIS.

7 - Nova orientação dos neurônios por meio da

Gastronomia Combinada \& da Respiração.

8 - Distribuição de manuais entre sexólogas (os)

explicando por que o coito anal derruba o Kapital.

9 - Banquetes oferecidos à população pela Federação

das Indústrias.

10 - Provocar o surgimento da Bossa-Nova Metafísica

\& do Pornosamba.

O Estado mantém as pessoas ocupadas o tempo integral

para que elas NÃO pensem eroticamente, poeticamente,

libertariamente. Novalis, o poeta do romantismo

alemão que contemplou a Flor Azul, afirmou: "Quem

é muito velho para delirar evite reuniões juvenis. Agora

é tempo de saturnais literárias. Quanto mais variada a vida tanto melhor".

Assino e dou fé,

Roberto Piva

SP 1983

Hora Cósmica do Tigre 


\section{Referências}

AMOSSY, R. (org.) Imagens de si no discurso: a construção do ethos. São Paulo: Contexto, 2005.

BARROS, D. L. P. de (2007). Teoria semiótica do texto. São Paulo: Ática (2002). Teoria do discurso: fundamentos semióticos. São Paulo: Humanitas/FFLCH/USP.

Semiótica e retórica: um diálogo produtivo. In: LARA PROENÇA MUNIZ, G.;

MACHADO, I. L.; EMEDIATO, W. (Org.). Análises do discurso hoje II. Rio de Janeiro: Nova Fronteira, 2008, p. 27-41.

BARTHES, Roland. (1984) A Câmera clara: nota sobre a fotografia. Rio de Janeiro: Nova Fronteira.

BERTRAND. D. (2003). Caminhos de semiótica literária. São Paulo: Edusc.

COHN, S. (2009). Encontros: Roberto Piva. São Paulo: Azougue Editorial.

DISCINI, N. Ethos e estilo. In: MOTTA, A. R.; SALGADO, Luciana et al. (Org.). Ethos discursivo. São Paulo: Contexto, 2008, p. 33-55. . (2004-06) Uma estética, uma ética. In: Revista Língua e Literatura, no 28. São

Paulo: FFLCH-USP.

- (2005). Heteroneidade constitutiva e formações ideológicas. In: A comunicação nos textos. São Paulo: Contexto.

FARIA, A (Org.) (2007). Poesia e vida: anos 70. Juiz de Fora: Ed. UFJF.

FIORIN, J.L. (1996). As astúcias da enunciação. São Paulo: Ática. 
(2004) "Uma concepção discursiva de estilo". In: O olhar a deriva. Mídia, significação e cultura. Org. CAÑIZAL, E. P; CAETANO, K.E. São Paulo: Annablume, p. 169-193. (2008) Em busca do sentido: estudos discursivos. São Paulo: Contexto.

FLOCH, J.M. (2002). Tués dans l'oeuf! - les enjeux sémiotique des différentes philosophies de pub. In: Sémiotique, marketing et communication. $2^{\mathrm{a}}$ ed. Paris: PUF (1985). Petites mythologie de l'oeil et de l'esprit. Paris-Amsterdam: Hadès-

Benjamins

FONTANILLE, J. (2007). Semiótica do discurso. Trad. PORTELA, J. C. São Paulo: Contexto.

FONTANILLE, J. e ZILBERBERG, C. (2001). Tensão e Significação. Trad. LOPES, I. C, TATIT, L. e BEIVIDAS, W. São Paulo: Discurso Editorial/Humanitas.

GREIMAS, A. J. (1966). Sémantique structurale. Paris: Larousse. (2002). Da imperfeição. Trad. OLIVEIRA, A. C. São Paulo: Hacker Editores. (1970). Du sens I: essais sémiotiques. Paris: Seuil. (1983). Du sens II: essais sémiotiques. Paris: Seuil. e outros (1976). Ensaios de semiótica poética. Trad. DANTAS, H. L. São Paulo: Cultrix.

GREIMAS, A. J. e COURTÉS, J. (2008). Dicionário de Semiótica. São Paulo: Ática. GREIMAS, A. J. e FONTANILLE, J. (1994) Semiótica das paixões. São Paulo: Ática. HARKOT-DE-LA-TAILLE, Elizabeth; TAILLE, Yves de La. (2004). Construção ética e moral de si mesmo. In: SOUZA, Maria Thereza Costa Coelho de. (Org.). Os sentidos de construção: o si mesmo e o mundo. São Paulo, v. 1, p. 69-101. 
HUNGRIA, C.; D’ELIA, R (2011). Os dentes da memória.Rio de Janeiro: Azougue editorial.

LOPES, I. C e ALMEIDA, D. C (Orgs.) (2011). Semiótica da Poesia. Exercícios práticos. São Paulo: Annablume.

MAINGUENEAU, D. (2008). A propósito do ethos. In: MOTTA, A. R.; SALGADO, Luciana et al. (Org.). Ethos discursivo. São Paulo: Contexto, p. 11-29 (2008). Problemas de ethos. In: Cenas da Enunciação. São Paulo: Parábola.

PIETROFORTE, A. V. S. (2011). O discurso da poesia concreta: uma abordagem semiótica. São Paulo: Annablume / Fapesp (2009). Análise textual da história em quadrinhos: uma abordagem semiótica da obra de Luiz Gê. São Paulo: Annablume. (2008). Tópicos de semiótica: modelos teórico e aplicação. São Paulo: Annablume. (2010). Semiótica visual: os percursos do olhar. $2^{\mathrm{a}}$ ed. São Paulo: Contexto (2011). Análise do texto visual: a construção da imagem. $2^{\mathrm{a}}$ ed. São Paulo: Contexto.

PIVA, R. (2005). Um estrangeiro na legião, obras reunidas volume I. São Paulo: Globo. (2006). Mala na mão \& asas pretas, obras reunidas volume II. São Paulo: Globo. (2008). Estranhos sinais de saturno, obras reunidas volume III. São Paulo: Globo. (2009). Paranoia. São Paulo: Instituto Moreira Salles.

SAUSSURE, F. de (1997). Curso de linguística geral. São Paulo: Cultrix. (?). "As palavras sobre as palavras"

ZILBERBERG, C. (2006). Razão e poética do sentido. Trad. LOPES, I. C, TATIT, L e BEIVIDAS, W. São Paulo: Edusp. 
Dicionário Priberam da Língua Portuguesa. Disponível em: <http://www.priberam.pt/dlpo/default.aspx $>$ Acesso em: 30 de março de 2013. 